A FEA e a USP respeitam os direitos autorais deste trabalho. Nós acreditamos que a melhor proteção contra o uso ilegítimo deste texto é a publicação online. Além de preservar o conteúdo motiva-nos oferecer à sociedade o conhecimento produzido no âmbito da universidade pública e dar publicidade ao esforço do pesquisador. Entretanto, caso não seja do interesse do autor manter o documento online, pedimos compreensão em relação à iniciativa e o contato pelo e-mail bibfea@usp.br para que possamos tomar as providências cabiveis (remoção da tese ou dissertação da BDTD). 
UNIVERSIDADE DE SÃO PAULO

FACULDADE DE ECONOMIA, ADMINISTRAÇÃO E CONTABILIDADE DEPARTAMENTO DE ADMINISTRAÇÃO

ASPECTOS DO USO DA COMUNICAÇÃO PERSUASIVA

NO MARKETING SOCIAL: O CASO DA OPERAÇÃO RODÍZIO PARA PROTEÇÃO AMBIENTAL

RICARDO MARCELO GIACON

Orientadora: Profa. Dra. Ana Akemi lkeda

SÃO PAULO

2000 
REITOR DA UNIVERSIDADE DE SÃO PAULO

Prof. Dr. Jacques Marcovitch

DIRETOR DA FACULDADE DE ECONOMIA, ADMINISTRAÇÃO E CONTABILIDADE

Prof. Dr. Eliseu Martins

CHEFE DO DEPARTAMENTO DE ADMINISTRAÇÃO

Prof. Dr. Cláudio Felisoni de Ângelo 
UNIVERSIDADE DE SÃO PAULO

FACULDADE DE ECONOMIA, ADMINISTRAÇÃO E CONTABILIDADE DEPARTAMENTO DE ADMINISTRAÇĀO

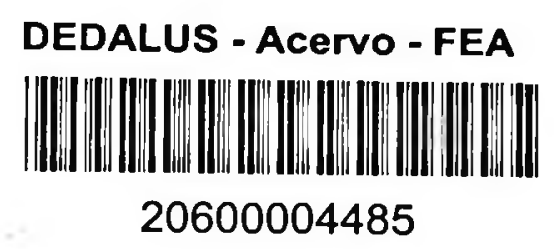

\section{ASPECTOS DO USO DA COMUNICAÇÃO PERSUASIVA NO MARKETING SOCIAL: O CASO DA OPERAÇÃO RODÍZIO PARA PROTEÇĀO AMBIENTAL}

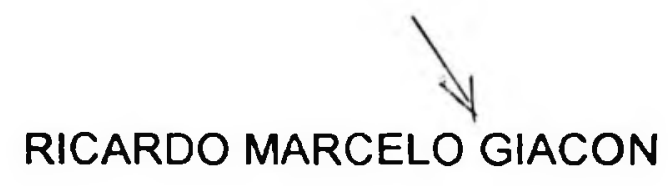

Orientadora: Profa. Dra . ANA AKEMI IKEDA

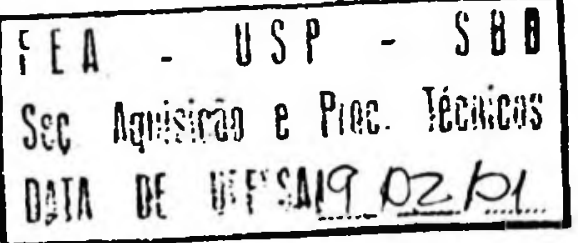

Dissertação apresentada ao Departamento de Administração da Faculdade de Economia, Administração e Contabilidade da Universidade de São Paulo como parte dos requisitos para a obtenção do título de Mestre em Administração 


\section{FICHA CATALOGRÁFICA}

Giacon, Ricardo Marcelo

Aspectos do uso da comunicação persuasiva no marketing social : o caso da operação rodizio para proteção ambiental / Ricardo Marcelo Giacon. - São Paulo : FEA USP, 2000.

p.

Dissertação - Mestrado

Bibliografia.

1. Comunicação em marketing 2. Marketing social 3. Administração - Aspectos ambientais I. Faculdade de Economia, Administração e Contabilidade da USP

$$
\text { CDD }-658.8
$$



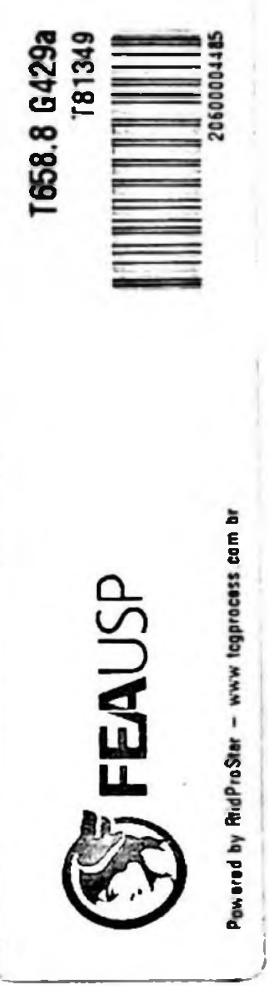

Ao meu pai (in memorian)

Ao Alexandre e à Neusa, pelo carinho e paciência À minha mãe e familiares, pelo apoio e incentivo 


\section{AGRADECIMENTOS}

Agradeço a Deus pela oportunidade e inspiração me iluminando no desenvolvimento dessa dissertação, e pela ajuda que sempre recebi em momentos difíceis por que passei em um periodo crítico da minha vida, e a todos que contribuiram e me ajudaram, por quem tenho um grande sentimento de gratidão, sendo impossivel agradecer a todos.

Este trabalho de dissertação representa muito mais do que uma exigência para obtenção do título de mestre, pois assumi o compromisso moral de utilizar meus conhecimentos em prol do crescimento e benefícios da sociedade, contribuindo para o desenvolvimento de um mundo melhor. Contudo, torna-se dificil elencar as pessoas e entidades às quais sou grato, mas há alguns que gostaria de demonstrar a minha gratidão de uma forma especial:

- Ao meu pai (in memorian), pelos poucos anos de convivio, mas que deixou um grande legado quando me dizia: "...que o saber não ocupa lugar, e que o conhecimento deve ser disponibilizado para aprimorar a sociedade".

- Ao meu filho Alexandre e à minha esposa Neusa, pela paciência, carinho e momentos de privação no convívio familiar. 
- À minha mãe, que sozinha educou meus irmãos e eu.

- À Professora Ana Akemi Ikeda, por quem tenho um agradecimento especial pela orientação, incentivo, apoio e estímulo no campo acadêmico e pessoal, com sua experiência e sabedoria me auxiliando no caminho a percorrer, demostrando ser realmente uma grande professora.

- Aos professores Marcos Cortez Campomar e Jorge Machado, pelas importantes sugestões e contribuições no projeto de dissertação na apresentação do exame de qualificação.

- Aos grandes amigos Julia S. Alves, Marcus Bucci e Paulo Afonso Garcia, que sempre incentivaram nos estudos.

- A todos os professores do curso de pós-graduação, por quem tenho grande carinho e admiração, em especial pelos professores Almir Ferreira de Sousa e Isak Kruglianskas, pelas contribuiçōes em minha vida profissional.

- Em especial às meninas do pós e secretaria (Valéria, Cida, Cristina, Marcia, Heloisa e Fabiana), pela forma sempre atenciosa e pelo estímulo e apoio que sempre me deram com muita paciência, tornando impossivel desenvolver o curso sem suas colaborações.

- À SMACETESB e CAPES, pelo apoio e colaboração. 
- Aos amigos e colegas da Assessoria de Comunicação da SMAVCETESB, pelo carinho, apoio e incentivo que sempre me deram, em especial a Edna, Fernando Coelho e Wagner B. Belmonte.

- Às cunhadas, cunhado, e sogra (in memorian), pelo apoio, carinho e incentivo, em especial ao Carlos Sérgio.

- À Regina Grossi pela extrema dedicação na revisão do texto.

- A todos que direta ou indiretamente contribuiram para minha formação pessoal e profissional. 


\section{SUMÁRIO}

LISTA DE FIGURAS + i

LISTA DE QUADROS ii

LISTA DE TABELAS iii

LISTA DE ABREVIATURAS iv

RESUMO vi vi

ABSTRACT vii

$\begin{array}{ll}\text { INTRODUÇĀO } & 1\end{array}$

CAPÍTULO 1 - JUSTIFICATIVA DO TEMA E DESCRIÇĀO DO PROBLEMA

DE PESQUISA

8

CAPITULO 2 - REVISĀO BIBLIOGRÁFICA DO TEMA MARKETING SOCIAL E COMUNICAÇĀO PERSUASIVA

2.1. Visão geral do marketing

2.2. A evolução do conceito de marketing

2.3. A ampliação do conceito

2.4. A importância do ambiente social nas filosofias e decisões de Marketing

2.5. A variável ambiental na estratégia organizacional 68

2.6. Educação Ambiental 71

2.7. Atividades de marketing social - sistema de informações $\quad 74$

2.8. O processo de comunicação 89

2.9. A comunicação no composto promocional 92 
3.1. Metodologia da pesquisa 98

3.2. A escolha do estudo de caso como estratégia de pesquisa 106

3.3. Estudo de caso - design da pesquisa 118

3.4. Desenvolvimento do protocolo do estudo de caso 125

3.5. Coleta de dados 128

3.6. Fontes de informações 131

3.7. Análise dos dados 135

3.8. Relatório de pesquisa do estudo de caso 136

CAPÍTULO 4 - PROCEDIMENTOS - ESTUdO DO CASO OPERAÇÃO RODÍZIO 141

4.1. Protocolo de pesquisa da Operação Rodízio 143

4.1.1. Visão geral do estudo de caso 143

4.1.2. Procedimentos no trabalho de campo 146

4.1.3. A questões do estudo de caso 149

4.1.4. Análise dos dados $\quad 150$

4.1.5. relatório do estudo de caso 151

CAPÍTULO 5 - CASO DO PROGRAMA DE RESTRIÇĀO À CIRCULAÇĀO DE VEÍCULOS AUTOMOTORES NA REGIÃO METROPOLITANA "OPERAÇÃO RODÍZIO 1995 A 1998"

5.1. Um breve panorama - globalização e consciência ecológica 152

5.2. Estado de São Paulo - Qualidade do ar, poluição atmosférica e reflexos na saúde

5.3. O sistema estadual do meio ambiente - SISEMA 166

5.3.1. Estrutura administrativa 166

5.3.2. A CETESB 170

5.4. Aspectos jurídicos e contestaçōes $\quad 172$

$\begin{array}{ll}\text { 5.5. O rodízio da prefeitura } & 177\end{array}$

5.6. Implantação e estrutura da Operação Rodízio 178

5.7. A campanha 1995 a $1998 \quad 180$

5.8. Recursos e divulgação 185

5.9. Os meios de comunicação 190

5.10. Resultados da campanha 196

5.11.Análise do caso na ótica do marketing social e comunicação persuasiva

5.12. O conceito de marketing social da operação rodízio 203

5.13. Sistema de informações e pesquisa 206

5.14. Segmentação e posicionamento da operação $\quad 210$

5.15. Composto do marketing social $\quad 214$ 
Capítulo 6 - Conclusōes, Recomendaçōes e Limitaçōes

6.1. Conclusões e recomendações

6.2. Limitações

Referências bibliográficas

Anexos

Apêndice 


\section{LISTA DE FIGURAS}

1 Estrutura dos fluxos em uma moderna economia de troca

2 Relação de troca total 28

3 As três dimensōes do marketing $\quad 35$

$4 \quad$ Modelo de fatores que conduzem às mudanças sociais $\quad 59$

$5 \quad$ Sistemas de informaçōes de marketing 86

6 Elementos de um sistema de informaçöes de marketing completo 88

7 O processo de comunicação 90

8 Métodos de pesquisa $\quad 99$

9 Métodos de pesquisa empirica 109

10 Tipos básicos de designs para estudos de casos 121

11 Delineamento de estudo de único caso 123

12 Estrutura do SISEMA 169

13 Estrutura da Operação Rodízio 179 


\section{LISTA DE QUADROS}

1 Entidades que mais deveriam se responsabilizar pelo combate aos problemas ambientais

64

2 Tipos de indústrias que mais prejudicam o meio ambiente (\%) 65

$3 \quad$ Tipos de estrutura de relatórios de estudo de casos 139

4 Espaço ocupado na mídia 192 


\section{LISTA DE TABELAS}

$1 \quad$ O escopo de marketing $\quad 52$

2 Classificação de informações 82

3 Situações relevantes para estratégias de pesquisa 113

4 Principais poluentes, fontes e impactos à saúde e meio ambiente 160

5 Redução relativa de monóxido de carbono de acordo com as fontes 199 


\section{LISTA DE ABREVIATURAS}

- ANTP - Associação Nacional dos Transportes Públicos

- Cedec-Centro de Estudos de Cultura Contemporânea

- CEDEC - Coordenadoria Estadual de Defesa Civil

- CET - Companhia de Engenharia de Tráfego

- Cetesb - Companhia de Tecnologia de Saneamento Ambiental

- CPTM - Companhia Paulista de Trens Metropolitanos

- DER - Departamento de Estradas e Rodagem

- DERSA - Desenvolvimento Rodoviário S/A

- EMTU - Empresa Metropolitana de Transportes Urbanos

- FEPASA - Ferrovia Paulista S.A.

- Greenpeace - organização internacional de defesa e luta contra as agressões ao meio ambiente

- Ibama - Instituto Brasileiro do Meio Ambiente e dos Recursos Naturais Renováveis

- IE - Instituto de Engenharia

- INMETRO - Instituto de Metrologia e Qualidade Industrial

- Metrô - Companhia Metropolitana de São Paulo

- MICT - Ministério da Indústria, Comércio e Turismo

- MMA - Ministério do Meio Ambiente, de Recursos Hídricos e Amazônia Legal

- PETROBRÁS - Petróleo Brasileiro S.A. 
- PMSP - Prefeitura do Município de São Paulo

- SCTDE - Secretaria Estadual da Ciência, Tecnologia e Desenvolvimento Econômico

- SE - Secretaria Estadual da Educação

- SEE - Secretaria Estadual de Energia

- SEF - Secretaria Estadual da Fazenda

- SES - Secretaria Estadual de Saúde

- SMA - Secretaria Estadual do Meio Ambiente

- SMT - Secretaria Municipal dos Transportes

- SSP - Secretaria Estadual de Segurança Pública

- ST - Secretaria Estadual dos Transportes

- STM - Secretaria Estadual dos Transportes Metropolitanos

- SVMA - Secretaria Municipal do Verde e Meio Ambiente

- USP - Universidade de São Paulo 


\section{RESUMO}

O objetivo do presente trabalho de dissertação é analisar o conceito e as atividades de comunicação persuasiva de marketing social e sua aplicabilidade em uma organização. Para atingir esse objetivo buscou-se elaborar um referencial teórico retomando conceitualmente o marketing até as primeiras discussōes sobre o marketing social, e sobre os conceitos de marketing e comunicação.

Optou-se por realizar uma pesquisa exploratória quanto à realidade a ser estudada, utilizando o método do estudo de caso, por se tratar de um tema muito pouco estudado, sob a ótica do Estado, oferecendo produtos e serviços e utilizando estratégias de marketing para atingir seu público-alvo, a sociedade. Como foco desta análise, foi selecionado o Programa de Restrição à Circulação de Veículos Automotores na Região Metropolitana - "Operação Rodízio 1995 a 1998" da SMANCETESB que implantou o rodízio de veículos como proteção ambiental, com enfoque na conscientização e educação do cidadão sobre os problemas de poluição na saúde humana, implicando em uma mudança de comportamento da sociedade.

Todos os passos da pesquisa de campo e dados gerais do estudo foram reunidos no Protocolo da Pesquisa, $e$ os resultados demonstraram que embora tivesse sido desenvolvidas açōes de marketing social e comunicação persuasiva, e ter havido uma mudança significativa no comportamento da sociedade em relação ao hábito de deixar um dia por semana de rodar com o veículo, a população não percebeu o crodízio como proteção ambiental, mas sim como um ação para melhorar ô trânsito da cidade. Conclui-se que não houve um posicionamento claro da operação, e que as açōes de marketing e comunicação persuasiva não conseguiram ser implementadas como recomenda o referencial teórico. 


\section{ABSTRACT}

This thesis main goal is to analyze the concepts and activities of persuasive communication of social marketing and its aplicability in an organization. This goal is reached) by searching theoretical references in the literature, returning conceptionally untill first argues on social marketing and about marketing and communication concepts.

It was chosen an exploratory research related to the realities to be studied, using study of case method, because this is a theme rarely studied, under "state point of view", offering products and services, using marketing strategies to reach their target public: the society.

The central point selected for this analysis was "Restriction of Engines Veichles Circulation in Metropolitan Area (Operação Rodizio)", 1995 to 1998 , SMAVCETESB which was implemented for environmental protection focusing the citzen awareness and education on pollution concerns related to human health, with changes in society behaviour as a consequence.

All research steps in the field and general data of this study were gathered in the Research Protocol and results showed, although social marketing actions and persuasive communication had been developed, and there were significant changes in the behaviour society, related not to use cars once a week, population has not considered this program as environmental pollution, but a way to get better the traffic in the city, instead.

At last, it was concluded there was not a clear positioning in this program and marketing actions and persuasive comunication did not get to be implemented as literature recomends. 


\section{INTRODUÇÃO}

"O que ocorrer com a terra recairá sobre os filhos da terra. 0 homem não tramou o tecido da vida; ele é simplesmente um de seus fios. Tudo o que fizer ao tecido, fará a si mesmo." Chefe Seatle (1854). . $^{\text {A }}$

Durante toda a história da humanidade, o homem cresceu e se desenvolveu em um mundo onde os recursos naturais eram abundantes e não considerou que um dia eles poderiam se esgotar.

Hanan; Batalha (1995) em seus estudos relatam que a relação entre os seres humanos e a natureza sempre se caracterizou por um processo de luta, de domínio, de posse, e não de harmonia. "Na percepção humana, tudo era perpetuamente abundante; a escassez não existia. Isso gerou uma ética de desenvolvimento cujo único limite era a capacidade tecnológica disponivel para atingir os objetivos determinados. Tal situação persiste até os dias de hoje, embora largos segmentos da sociedade já exijam uma revisão de tal comportamento cultural."

Os autores consideram que essa visão é decorrente das diversas teorias concebidas para o desenvolvimento socioeconômico que sempre contemplaram 0 benefício material sem considerar o aspecto

A Apèndice - Cópia da Carta do Chefe Seatle distribuida pela ONU - Organização das Naçōes Unidas (Programa para o Meio Ambiente) reproduzida em folder da CETESB - Companhia de Tecnologia de Saneamento Ambiental 
ambiental. Segundo esses autores, provavelmente porque o homem era incapaz de perceber e compreender o impacto provocado na natureza. No periodo que antecedeu a revolução industrial, a velocidade da evolução e das mudanças tecnológicas era lenta e tinha uma capacidade limitada de alterar o meio.

No Brasil, não foi muito diferente, pois desde os primórdios da colonização, a ocupação de seu território aconteceu através de sucessivos ciclos extrativos, como os de pau-brasil, castanha do Pará, cacau, borracha, café, etc.

É notória a indicação de que o grau de conscientização da população sobre as causas ecológicas tem aumentado e que a população atribui ao Govemo a maior responsabilidade pela proteção e ações em relação à preservação do meio ambiente.

O mundo está passando por um processo dinâmico de globalização: quebra de barreiras alfandegárias, formação de blocos comerciais, novas tecnologias de comunicaçāo. E o Governo tem tido uma grande importância de atuação na economia e no desenvolvimento do País.

O surgimento da CETESB está ligado a um estágio crítico que foi atingido na relação entre o desenvolvimento econômico do Estado de São Paulo e a preservação do meio ambiente. O ritmo acelerado do crescimento industrial gerava à população grandes oportunidades de 
trabalho, porém proporcionava a essa mesma população aumentos expressivos em nivel de poluição ambiental.

Essa relação de crescimento econômico com o meio ambiente tinha que ser equacionada, pois resultava em alto custo para a qualidade de vida da população.

Em 1968, através de uma lei que unificava as atividades de vários laboratórios vinculados aos órgãos estaduais, criou-se uma única empresa com o objetivo de proporcionar base tecnológica para o aceleramento de programas de saneamento básico, constituindo um centro de estudos, pesquisas, ensaios e exames, levantamentos e treinamento de pessoal no campo de engenharia sanitária.

Atualmente a CETESB é um centro difusor da tecnologia de saneamento ambiental para o Brasil e para a América Latina, com prestigio internacional e um quadro de técnicos de nível médio e superior, altamente especializados, atuando efetivamente em todas as áreas de preservação e recuperação ambiental, contribuindo para a melhoria da qualidade de vida dos habitantes do Estado de São Paulo.

A Cetesb faz parte do Sistema Estadual do Meio Ambiente, sendo a Secretaria de Estado do Meio Ambiente constituida pelo Instituto Florestal, Instituto Geológico, Instituto de Botânica, Fundaçāo para 
Conservação e Produção Florestal, CETESB e Polícia Florestal e de Mananciais.

A falta de planejamento urbano na cidade de São Paulo deu lugar a um sistema viário que não comporta o fluxo de veiculos, produzindo congestionamentos diários. Os maiores problemas de poluição do ar são decorrentes de gases e partículas lançados na atmosfera, decorrentes de fontes industriais e de veiculos automotores que constituem um dos pontos mais críticos de poluição do ar, em virtude da emissão de seus gases.

No interior do Estado, a situação é também preocupante, pois "...o Interior se caracteriza ou pela existência de problemas isolados ou por cidades cujo tamanho já merece um tipo de atenção especial que as diferencie do resto do Estado." Brunacci (1994).

A empresa desenvolve programas de tecnologia e controle da poluição do ar, água e solo, treinamento e transferência de tecnologia, planejamento ambiental, assistência aos municípios e cooperação institucional com outras entidades no plano nacional e internacional.

Quanto à poluição do ar, a CETESB exerce a fiscalização das fontes móveis e estacionárias da poluição atmosférica e o controle da qualidade do ar, que "...apesar de toda ação preventiva e corretiva, a qualidade do ar ainda não é satisfatória, em função da movimentação dos 
veículos automotores que geram grande carga de poluentes na atmosfera das regiões urbanas." Brunacci (1994).

Como ações de combate à poluição atmosférica, a CETESB vem desenvolvendo um conjunto de medidas, como "Caça-Fumaça", "PROCONVE", "Qualidade dos Combustiveis", "Monitoramento da Qualidade do Ar", "Operação Inverno", "Poluição Industrial", "I/M", e em 1995, introduziu em suas ações a "Operação Rodizio".

A "Operação Rodízio" ocorre nos meses de inverno, quando as condiçōes climáticas sāo mais desfavoráveis à dispersāo de poluentes, e tem como objetivo principal a melhoria da qualidade do ar, além de educar o cidadão para que ele possa se conscientizar sobre os efeitos da poluição na saúde humana e provocar mudanças de hábitos após o periodo de vigência.

A CETESB tem em suas atribuições estatutárias o desenvolvimento e a transferência de tecnologia, além de controlar a qualidade do meio ambiente. Assim, oferece produtos e serviços à sociedade.

Por outro lado, como o Estado através de sua empresa de controle ambiental tem atuado nas questões ambientais? Quais são suas estratégias e ações para contribuir com a qualidade ambiental no Estado de São Paulo, atuando de forma preventiva e corretiva? 
Assim, nesta dissertação, procura-se analisar como é o processo de comunicação da SMACETESB focando a Operação Rodizio no período de 1995 a 1998.

Considerando que a Operaçāo Rodízio tem como enfoque a conscientização e a educação do cidadão sobre os problemas da poluição na saúde humana, o que implica em uma mudança de comportamento da sociedade, o referencial teórico que envolve o conceito de mudanças sociais e o que pode facilitar estas mudanças centra-se nos conceitos do marketing social.

Inicia-se com uma retomada conceitual do marketing até as primeiras discussões sobre o marketing social, no qual serāo abordados com uma revisão bibliográfica os conceitos de marketing, focando conceitos de comunicação sob o aspecto ambiental.

Utiliza-se o estudo de caso na pesquisa e análise do processo de comunicação na SMAVCETESB focando a "Operação Rodízio" com o ambiente social para identificar se os conceitos de marketing são utilizados em suas ações.

O trabalho foi dividido em cinco capitulos, sendo que no capitulo 1, há o início com uma explanação sobre a justificativa e a descrição do problema de pesquisa, contextualizando a situação do caso a ser estudado. 
No capítulo 2, há uma revisão bibliográfica da evolução dos conceitos de marketing até as primeiras discussões sobre marketing social e comunicação persuasiva.

No capítulo 3 , destaca-se o planejamento da pesquisa, falando sobre a metodologia de pesquisa e a escolha da estratégia adotada, bem como o design da pesquisa.

O capítulo 4 apresenta os procedimentos e o protocolo de pesquisa da Operação Rodízio, e o capítulo 5 mostra o caso da Operação Rodízio no período de 1995 a 1998, com as atividades de marketing e comunicação persuasiva desenvolvidas.

E, por fim, no capítulo 6, são apresentadas as conclusões e as limitaçōes do estudo. Adotou-se como procedimento apresentar as referências bibliográficas de cada capítulo no final do trabalho com os anexos. 


\section{CAPÍTULO 1 - JUSTIFICATIVA E DESCRIÇÃO DO PROBLEMA DE PESQUISA}

O surgimento da CETESB está ligado a um estágio crítico que foi atingido na relação entre o desenvolvimento econômico do Estado de São Paulo e a preservaçāo do meio ambiente. O ritmo acelerado do crescimento industrial gerava à população grandes oportunidades de trabalho, porém proporcionava a essa mesma populaçāo aumentos expressivos nos niveis de poluição ambiental.

Essa relação de crescimento econômico com o meio ambiente tinha que ser equacionada, pois resultava em alto custo para a qualidade de vida da população. Em 1968, através de uma lei que unificava as atividades de vários laboratórios vinculados aos órgãos estaduais, criouse uma única empresa com o objetivo de proporcionar base tecnológica para - aceleramento de programas de saneamento básico, constituindo um centro de estudos, pesquisas, ensaios e exames, levantamentos e treinamento de pessoal no campo de engenharia sanitária.

Com o passar do tempo, suas atribuições e atividades foram ampliando e compreendendo a adoção de medidas preventivas e corretivas referentes ao controle da emissão de poluentes que possam colocar em risco a saúde pública, a flora, a fauna ou os recursos naturais do Estado. 
Uma das atividades mais conhecidas da CETESB é a atuação do controle da poluição atmosférica, destacando o trabalho desenvolvido na região de Cubatão, onde houve uma significativa melhora das condições ambientais na região.

A falta de planejamento causou o processo de urbanização na cidade de São Paulo de forma desequilibrada. Essa desorganização somada às políticas industriais de desenvolvimento urbano baseadas em cenários de crescimento contínuo, onde o enfoque é apenas econômico, tem levado a questão da poluição do ar na região metropolitana de São Paulo a atingir niveis críticos.

O processo de crescimento nos grandes centros urbanos tem trazido a deterioração da qualidade do ar, conforme apontado pela CETESB-Operação Rodizio 95: do Exercicio à Cidadania, (CETESB, 1996), dizendo o seguinte:

“...tema que ultimamente tem sido uma das principais preocupações relativas ao meio ambiente urbano.

A qualidade do ar urbano é determinada por um complexo sistema de fontes móveis (veículos automotores) e fixas (indústrias, queima de lixo, caldeiras, fornos, etc.). 
...No início dos anos 80 já se verificava que os veículos automotores representavam a maior fonte de emissão de poluentes atmosféricos.

Os padrões de qualidade do ar na Região Metropolitana de São Paulo, quando atingem o nivel de Emergência $e$ portanto evidenciando o risco iminente à saúde, ....devem ser tomadas medidas coercitivas de restrição de circulação de veículos, previstas na legislação ambiental, para salvaguardar a saúde pública."

Em 30 de julho de 1995, foi registrado um pico de ozônio com uma marca cinco vezes superior à recomendada pela Organização Mundial da Saúde, demonstrando que a situação se agravara e que uma medida deveria ser tomada.

No periodo de inverno, as condiçōes meteorológicas em geral são desfavoráveis, e portanto dificulta a dispersão de poluentes, assim, como uma medida alternativa e imediata para reduzir as emissões e proteger a saúde humana, com base nos dados de saúde pública, foi instituído em 1996, através de Lei Estadual, o Programa de Restrição à Circulação de Veículos Automotores na Região Metropolitana, conhecido como "Operação Rodizio".

O programa visa reduzir as emissōes dos poluentes de origem veicular, educar o cidadão para identificar as principais fontes 
emissoras de poluentes, conscientizar o cidadão sobre os efeitos da poluiçāo sobre a saúde humana, provocar mudanças de hábito que se estendam para além do período de vigência do Rodízios, etc.

Dessa forma, surge como problema de pesquisa identificar: Qual a situação das atividades de marketing e de comunicação na Agência Ambiental do Estado de São Paulo (SMA/CETESB), e como estas atividades influenciam o relacionamento com a sociedade e como é feito o processo de comunicação, especificamente no caso da “Operação Rodizio".

Na literatura, existem poucos trabalhos desenvolvidos no campo ambiental, sob a ótica do Estado, oferecendo produtos e serviços, e utilizando estratégias de marketing para atingir seu público-alvo, a sociedade.

Convém observar que o termo marketing muitas vezes é utilizado de forma incorreta pois seu desenvolvimento passou por diversos estágios, sendo inicialmente associado à distribuição, evoluindo para propaganda/publicidade e vendas em uma ótica apenas aplicada às empresas que objetivavam o lucro.

A evolução do marketing não se limitou apenas a transações comerciais e foi ampliado demonstrando que ele pode ser aplicado a outros 
setores, como serviços, empresas sem fins lucrativos, governamental, internacional, industrial, ambiental e tantos outros.

marketing social é um conceito pouco utilizado no Brasil, principalmente em empresas públicas que nem sempre o utilizam, sendo que o Estado desempenha um importante papel na sociedade alavancando o desenvolvimento econômico e social.

"A importância do setor público empresarial pode ser avaliada mediante a análise de sua participação nas principais macromagnitudes econômicas: no emprego, no valor agregado bruto e na formação bruta de capital fixo (investimento)". (administração de..., 1988)

Conforme apontado no relatório do grupo de trabalho intersecretarial Uma política de Estado de uso do poder de compra (SÃO PAULO, 1999) "o Poder Público, ainda que retraido pelo recente processo de privatizações, detém ainda uma vastíssima e diversificada capacidade de compra de materiais, senviços e investimentos, por conta de suas administrações direta e indireta."

O relatório Uma política de estado de uso do poder de compra (SĀO PAULO, 1999) analisa três grupos de entidades, tomando como base a Administração Direta, Universidades Públicas Estaduais e Administração Indireta, apontando que em 1998 a "Capacidade de Compra 
do Estado de São Paulo atingiu cerca de $R \$ 19,8$ bilhões, sendo $R \$ 9.996$ bilhões $(50,45 \%)$ em materiais, $R \$ 3.546$ bilhões $(17,90 \%)$ em serviços e $R \$$ 6.271 bilhões $(31,65 \%)$ em investimentos."

O relatório Uma política de Estado de uso do poder de compra (SÃO PAULO, 1999) ainda mostra que de abril a dezembro de 1998 "os gastos em serviços de construção civil, serviços técnicos especializados e serviços de nutrição e alimentação responderam por cerca de $46 \%$ dos gastos totais da Administração Direta em materiais e serviços, sendo que os gastos em materiais da área da saúde, alimentos em geral e veículos diversos corresponderam a cerca de $26 \%$ destes mesmos gastos totais."

Convém observar que segundo Corrêa (1986) "A empresa estatal é um tipo de organização que, embora se caracterize pela diferenciação dos objetivos e mantenha circulação direta com o poder governamental, também se comporta como um organismo preocupado em adequar bem seus recursos, atingir seus objetivos e assegurar a sua permanência."

O autor ainda afirma que em geral as empresas estatais são criadas para atuar em setores onde as empresas privadas não demonstram interesses em investir, uma vez que normalmente elas o fazem visando o lucro que o investimento irá gerar, observando que as estatais são mais identificadas com os interesses econômicos da sociedade e, em seu desempenho, considera o aspecto da responsabilidade social. 
Conforme Corrêa (1986), as empresas estatais são criadas apresentando uma ou mais das caracteristicas abaixo:

- "nivel de investimento imobilizado é muito elevado para ser feito por uma empresa privada;

- a taxa de retorno é baixa, tornando necessánio um prazo muito longo para se 'pagar o investimento';

- muitas vezes trabalha-se com preço subsidiado, procurando incentivar algum setor ou não aumentar a inflação;

- é área de segurança nacional."

Nota-se que a participação das empresas públicas é importante e desempenha diversos objetivos, como promover o desenvolvimento, superar uma alta aversão privada ao risco, coordenar atividades de infra e intersetoriais, assegurando o controle estatal sobre os setores considerados básicos.

Entre alguns beneficios, ressalta-se a contribuição para a instrumentalização da prática econômica governamental, atenuando ou compensando desequilibrios regionais e uma fonte de emprego, cujo principal beneficiário das atividades desenvolvidas é a comunidade em geral. 
Corrêa faz uma critica observando que em muitos casos uma empresa é criada com um objetivo, e forma-se uma cadeia de novas subsidiárias que não estão relacionadas às finalidades iniciais da empresa, desviando de sua proposta original.

Segundo a Revista Exame Melhores e Maiores (1999), o valor adicionado de uma empresa é representado pelo valor da riqueza gerada por uma empresa, e na lista das $\mathbf{2 0}$ maiores, 8 estatais lideram a relação, seguidas de 7 estrangeiras. A CETESB na relação das 50 maiores empresas estatais, por vendas, ocupa a $49^{a}$ posição.

Fica uma indagação, quanto o Estado gasta deste percentual na saúde, provocado por doenças respiratórias ou de outra natureza decorrente da poluição atmosférica? Esta dissertação não visa responder esta questão, mas ressaltar a importância da conscientizaçāo da população através da comunicação persuasiva utilizada no marketing social.

A SMACETESB em suas diretrizes objetiva proteger e contribuir para o aumento da qualidade ambiental e desenvolvimento sustentável do Estado de São Paulo, desempenhando campanhas educativas no rol de suas atividades, sensibilizando e mobilizando diversos setores da sociedade na busca de soluçōes para a melhoria da qualidade de vida. 
Destaca-se a importància da comunicaçāo no desenvolvimento de campanhas de informações públicas nesse processo, dando orientações para práticas ambientalmente corretas, ampliando a participação da sociedade e de sua conscientização sobre as causas ecológicas, facilitando o acesso de dados e informações de forma transparente que tragam soluçōes concretas para problemas de utilidade pública.

No caso da Operação Rodizio, ela visa uma mudança de hábito da populaçāo e de seu comportamento. $O$ marketing social contribuiria para reduzir as açōes de controle pelos órgāos responsáveis pela qualidade do meio ambiente, que passariam a concentrar seus esforços e recursos em açōes de prevenção e pesquisa de novas técnicas no controle ambiental, uma vez que a população estivesse mais consciente e passasse a agir como aliada nas causas ambientais.

Nesse contexto, a atividade de comunicação torna-se um elemento de vital importância para divulgar e repassar a tecnologia desenvolvida para a sociedade, que é o maior cliente do Estado, seja no segmento empresarial ou social, através de comunidades que vivem nas imediaçōes das fábricas e nas quais muitas vezes trabalham, propiciando o desenvolvimento econômico de uma região.

Portanto, a principal contribuiçāo deste trabalho é ampliar o conhecimento do processo de comunicação de marketing no campo das 
estatais, onde os trabalhos desenvolvidos em geral são orientados para provocar mudanças sociais ou disseminar idéias objetivando uma mudança de comportamento da sociedade.

O trabalho torna-se relevante por constituir uma contribuição ao campo da administração e focar um dos aspectos do macroambiente, pouco estudado, que tem forte influência nas indủstrias, empresas em geral e na sociedade. Ou seja, o órgão legislador de meio ambiente que tem em suas atribuiçōes o poder de fiscalização e o de transferência de tecnologia, ligado à saúde pública.

Em termos empiricos, pretende-se ampliar a análise do campo da comunicação nas ações de marketing em instituições não lucrativas e a conscientização sobre as questōes ambientais na sociedade, que trata de uma área administrativa muito pouco estudada e que está ganhando um espaço cada vez maior devido à deterioração do meio ambiente e das condições humanas na sociedade.

Assim, o objetivo a ser alcançado analisar o conceito e as atividades de comunicação persuasiva de marketing social e sua aplicabilidade em uma realidade empirica, identificando quais são as atividades desenvolvidas pela agência ambiental do Estado de São Paulo (SMACETESB) no processo de comunicação e especificamente, no caso da Operação Rodizio. 
Objetivando direcionar os esforços de levantamento bibliográfico e coleta de dados, são propostas algumas questōes que, se respondidas, visam atender ao propósito central deste trabalho, sendo:

- Qual o conceito de marketing social e comunicação persuasiva?

- Quais são as atividades do marketing social?

- Como é estruturado o marketing social na SMAVCETESB na Operação Rodizio?

- As atividades de comunicação da SMACETESB no caso específico da Operação Rodízio estão de acordo com a teoria de marketing social?

Espera-se dessa forma que este estudo possa contribuir para a ampliação de conhecimentos teóricos sobre a prática da comunicação persuasiva do marketing social aplicado a empresas estatais. 


\section{CAPÍTULO 2 - REVISÃO BIBLIOGRÁFICA DO TEMA MARKETING SOCIAL E COMUNICAÇĀO PERsuasiva}

Neste tópico, será feita uma revisão dos conceitos de marketing até as primeiras discussōes sobre o marketing social e a comunicação persuasiva.

\subsection{VISÃO GERAL DO MARKETING}

O termo marketing tem sido confundido como sendo apenas vendas e propaganda, porém essas são partes de um conjunto de ferramentas conhecidas como composto de marketing (ou mix de marketing) que trabalham juntas visando atingir um mercado.

O composto de marketing é definido por Kotler (1998) como sendo "...o conjunto de ferramentas que a empresa usa para atingir seus objetivos de marketing no mercado-alvo." Embora existam dezenas de 
ferramentas no composto de marketing. McCarthy apud Kotler 1 "popularizou uma classificação dessas ferramentas chamada os quatro Ps sendo produto, preço, praça (isto é distribuição) e gromoção".

Kotler, Armstrong.(1998) definem "...o marketing como o processo social e gerencial através do qual indivíduos e grupos obtém aquilo que desejam e de que necessitam, criando e trocando produtos e valores uns com os outros". Observando que o conceito de produto não se limita a objetos físicos, mas sim a qualquer coisa que seja capaz de satisfazer uma necessidade, sendo mais importante do que possuir um objeto físico a obtenção dos beneficios que ele proporciona.

Os autores ressaltam que a troca é o conceito central do marketing e que, para que ela seja efetuada, várias condiçōes devem ser satisfeitas, e que a transação é uma unidade de medida entre a troca de valores entre duas partes, lembrando que o marketing é constituido de ações cuja finalidade é obter uma resposta desejada de um público-alvo sobre algum produto, seja ele um objeto qualquer, serviço ou idéia.

O marketing inicia com as necessidades e desejos humanos, o que para Kotler; Fox (1994) o "Marketing existe quando pessoas decidem satisfazer suas necessidades e desejos através de troca. "Lembrando que

\footnotetext{
1 McCARTHY, E. J.. Basic Marketlng: a managerial approach. 12.ed.Homewood, IL: Irwin. 1996. Apud KOTLER, Philip; Administraçăo de Marketing - Análise, Planejamento, Implementaçăo Controle. $5^{\circ}$ ed. Săo Paulo. Editora Atlas S.A., 1998, p.97
} 
para sobreviver, as pessoas necessitam de alimentação, ar, água, abrigo, segurança e desejam recreação, educação e outros serviços.

A troca, segundo Kotler (1998), deve ser vista como um processo de criação de valor porque normalmente deixa as partes envolvidas em melhores condições do que antes da mesma ocorrer, e faz as seguintes distinções entre necessidade humana, desejos e demanda:

- "Necessidade humana é um estado de privação de alguma satisfação básica. As pessoas exigem alimento, roupa, abrigo, segurança, sentimento de posse e auto-estima. Essas necessidades não são criadas pela sociedade ou empresas. Existem na delicada textura biológica e são inerentes à condição humana.

- Desejos são carências por satisfações específicas para atender às necessidades. ...... Os desejos humanos são continuamente moldados e remoldados por forças e instituições sociais, incluindo igrejas, escolas, familias e empresas.

- Demandas são desejos por produtos especificos, respaldados pela habilidade e disposição de comprá-los. Desejos se tornam demandas quando apoiados por poder de compra."

Dessa forma, Kotler (1998) observa com essas distinções que, embora alguns críticos do marketing façam acusaçōes de que os 
especialistas de marketing criam necessidades ou induzem as pessoas a comprar coisas que não querem, as necessidades já existiam antes deles.

Portanto, as necessidades não sendo criadas, o marketing junto com outras forças sociais desperta e influencia os desejos, podendo promover uma idéia de que um determinado produto pode satisfazer uma necessidade.

Kotler (1998) observa ainda que não cria a necessidade, mas influencia a demanda ao oferecer um produto apropriado, de forma atraente e que seja adquirivel, facilmente disponivel aos seus consumidoresalvo. Lembrando que os consumidores escolhem seus produtos atribuindo um valor que "...é a estimativa de cada produto satisfazer a seu conjunto de necessidades", e que cada produto visa satisfazer um conjunto delas com capacidades diferentes.

Para Kotler; Fox (1994), uma orientaçāo de marketing tem a pressuposição de que a tarefa principal de uma instituição é "..determinar as necessidades e os desejos de mercados-alvo e satisfazê-los através do projeto, comunicação, fixação de preço e entrega de programas e serviços apropriados e competitivamente viáveis."

Os autores ainda afirmam que um profissional de marketing está capacitado para entender, planejar e controlar as trocas e pesquisar para compreender as necessidades e desejos do mercado, projetando uma 
oferta valiosa para atendê-lo, considerando a comunicação e as outras variáveis de marketing no tempo e no lugar certo.

Nessa linha de raciocínio, os autores formulam a seguinte definição:

“Marketing é análise, planejamento, implementação e controle de programas cuidadosamente formulados para causar trocas voluntárias de valores com mercados-alvo e alcançar os objetivos institucionais. Marketing envolve programar as ofertas da instituição para atender às necessidades e aos desejos de mercados-alvo, usando preço, comunicação e distribuição eficazes para informar, motivar e atender a esses mercados." Kotler; Fox (1994).

Dessa definição, deve-se considerar alguns pontos sobre o marketing, como:

1. existe um processo gerencial, uma vez que envolve análise, planejamento, implementação e controle;

2. é necessário estabelecer programas cuidadosamente formulados para desenvolver as atividades de marketing;

3. o marketing visa as trocas voluntárias, e uma organização deve formular produtos para oferecer ao mercado-alvo benefícios atraentes que possam produzir uma troca voluntária; 
4. identificar os segmentos de mercado, selecionar e decidir os mercadosalvo possiveis de atender;

5. para atender o mercado com maior eficácia, o planejamento eficaz de marketing deve ser voltado para os objetivos organizacionais como todas as unidades ;

6. a oferta da instituição deve ser voltada para as necessidades e desejos dos mercados-alvo e de seus consumidores, não para gostos dos vendedores;

7. utiliza o conjunto de ferramentas chamado de composto (ou mix) de marketing que envolve os quatro P's que são fatores controláveis da instituição para adequar a oferta aos desejos do mercado-alvo.

Nesse sentido, McCarthy; Perreault (1997) enfatizam que a seleção de um mercado-alvo e o desenvolvimento de um composto de marketing estão inter-relacionados, e uma estratégia de marketing deve ser avaliada e decidida em conjunto com os objetivos da empresa e não considerar compostos de marketing alternativos ou mercados-alvo.

Convém lembrar que o termo mercado originalmente se referia a um lugar especifico onde se reuniam vendedores e compradores para trocar os seus bens, que segundo Kotler (1998) "um mercado consiste de todos os consumidores potenciais que compartilham de uma necessidade ou desejo especifico, dispostos e habilitados para fazer uma troca que satisfaça essa necessidade ou desejo." O termo mercado é utilizado pelos homens de negócios para se referir a vários grupos de clientes, sendo 
abrangente, como mercados financeiros, filantrópicos, entre outros, os do próprio Governo que desempenha vários papéis oferecendo serviços públicos necessários.

Para o autor, todas as economias modernas operam em mercados e a economia de cada país, bem como do mundo inteiro, consiste de complexos conjuntos de mercados inter-relacionados que se unem através de processos de troca. O fluxo funciona com os consumidores vendendo sua força de trabalho. Recebem dinheiro para pagar seus impostos, seus bens e serviços adquiridos. Já o Govemo utiliza a receita arrecadada com impostos para comprar bens e serviços dos diversos mercados, para utilizá-los fornecendo serviços públicos.

Os mercados compram recursos e os transformam em bens e serviços, vendendo-os como produtos acabados para consumidores e intermediários. Para Kotler (1998), existem cinco mercados básicos que sāo demonstrados com seus fluxos de conexão, conforme segue figura 1: 


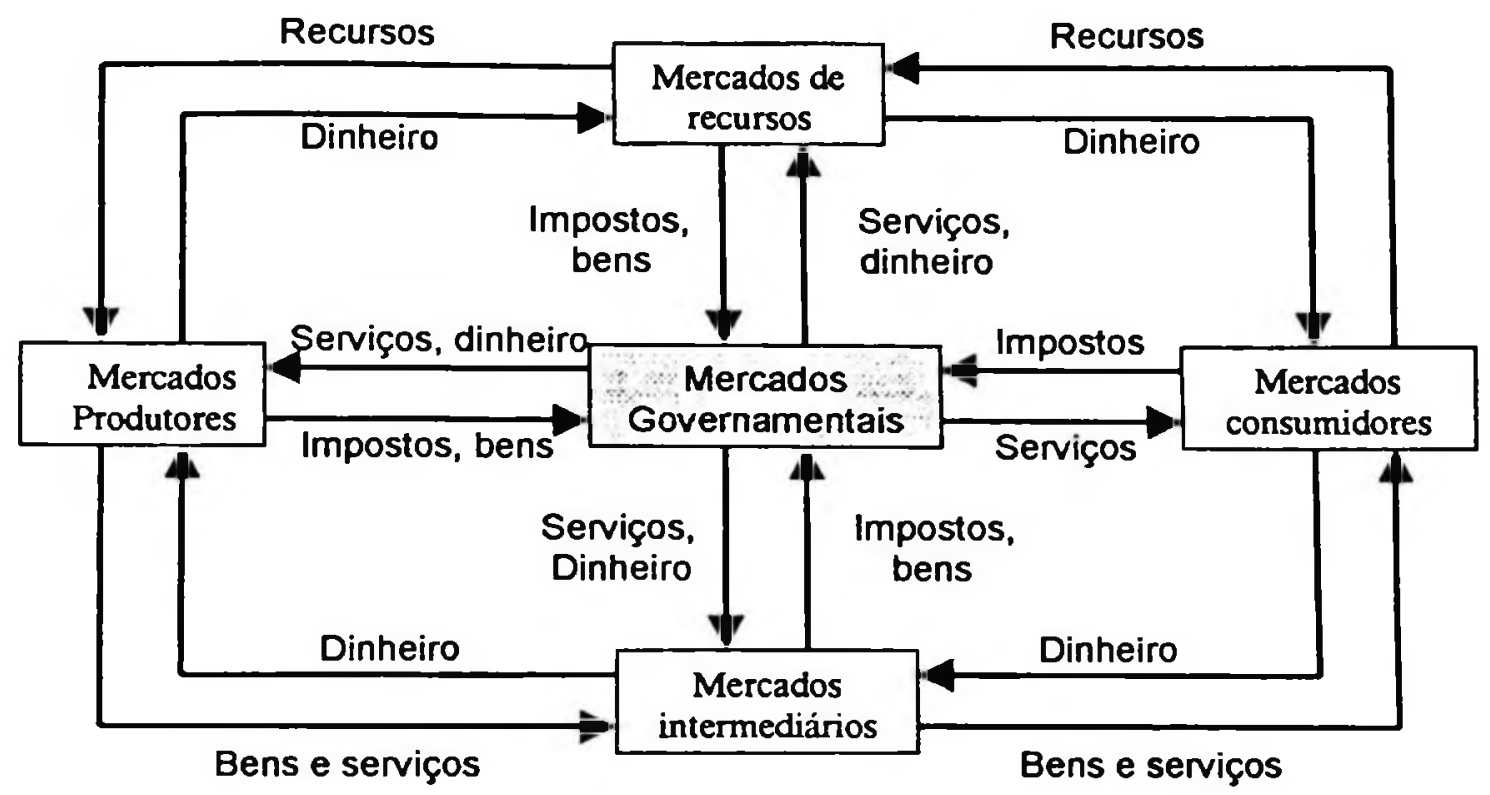

FIGURA 1: Estrutura dos fluxos em uma moderna economia de troca. Fonte: Kotler (1998, p.32)

Kotler (1994) ressalta que uma troca só é realizada quando existem duas partes e que cada uma delas tem algo que pode ser de valor para a outra parte, observando que "o valor está enraizado nos desejos humanos" e que para satisfazer esses desejos, existem três categorias:

1. OBJETOS: são bens que podem ser capazes de satisfazer certos desejos.

2. SERVIÇOS: que envolvem tempo, energia e/ou habilidade que um individuo pode desempenhar através de atos para satisfazer as necessidades da outra parte envolvida.

3. DINHEIRO: mercadoria que de forma geral é representada por cédulas e moedas que tem curso oficial e valor estabelecido como equivalente, permitindo a troca com uma outra parte por bens e serviços oferecidos que ela possa querer. 
O autor analisa que havendo duas unidades sociais engajadas na troca, deve-se determinar o conjunto de valores que seria mais eficaz em proporcionar uma reação desejada no mercado. No caso da relação cidadão/serviço público, citando como exemplo o Corpo de Bombeiros, há uma terceira parte envolvida, o Governo.

".... governo local, que entra na relação de troca com os cidadãos, de um lado, e com o corpo de bombeiros, de outro..... cidadão paga os impostos ao governo. Parte desses impostos ajuda o governo a manter o corpo de bombeiros. O corpo de bombeiros, em troca do trabalho e do dinheiro que recebe, fornece um serviço aos cidadãos e uma promessa de serviços ao governo. Se o corpo de bombeiros se tornar negligente ou ineficaz, arriscará perder o dinheiro do governo e terá menor reconhecimento dos cidadãos." Kotler (1994)

Na visāo de Kotler (1994), existe um processo de autotroca em que o comandante do Corpo de Bombeiros entendendo essa relação, a utiliza para motivar seus funcionários. Nesse processo, o bombeiro tem necessidade de estima da comunidade e de aprovação, e visando receber sentimentos positivos sobre si e evitar a culpa de fazer um trabalho ruim, ele desempenha bem suas atividades, criando um relacionamento de troca total, entre Governo, Corpo de Bombeiros e cidadāo. A figura que segue ilustra essa relaçāo. 


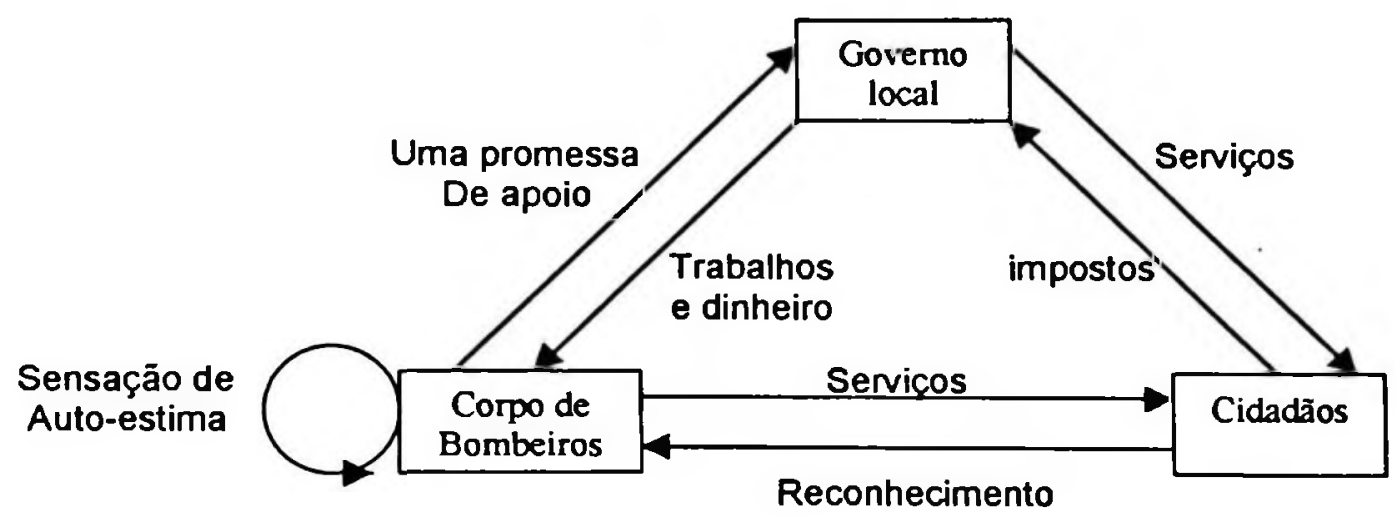

FIGURA 2: Relação de troca total

Fonte: Kotler, 1994, p.45

Kotler (1994) apresenta uma classificação ressaltando que as organizações surgem para atender um ou mais grupos ou públicos que, em cada caso especifico, podem ser identificados supostamente como o beneficiário principal das atividades da organização, complementando essa relação de troca total, sendo:

1. EMPRESAS DE NEGOCIOS - Organizaçōes que visam o lucro, como empresas, indústrias, lojas de atacado e varejo, bancos, etc., que trabalham com um mercado consumidor trocando bens e serviços por dinheiro e com o mercado de proprietários sendo seus principais beneficiários trocando capital por dividendos;

2. ORGANIZAÇOES DE SERVIÇOS - como museus, hospitais, agências de bem-estar social, e outras nessa linha que trabalham com mercados de clientes que são os maiores beneficiários trocando serviços por algum tipo de gratificaçāo ou audiência e com um mercado doador trocando dinheiro e tempo por gratidão; 
3. ASSOCIAÇÓES DE BENEFICIOS MÚTUOS - o mercado principal são seus membros, com quem trocam serviços por algum tipo de gratificação, tempo e energia, beneficiando principalmente seus associados; as principais organizaçōes são clubes, partidos políticos, sindicatos, seitas religiosas e associações de classe.

4. ORGANIZAÇÕES DE BEM-ESTAR PÚBLICO - são criadas pelo público objetivando atender aos interesses do público em geral, como Ministérios, Secretarias de Estado, Forças Armadas, Polícia, Corpo De Bombeiros e fundações filantrópicas. Seu mercado principal é o público com quem troca serviços por impostos. Beneficiam principalmente o público em geral.

Observando que um público, conforme definido por Kotler, Fox (1994) "é constituido de um grupo distinto de pessoas e/ou organizações que têm interesse real ou potencial em afetar uma instituição."

Nessa linha, Kotler (1994) classifica os públicos de uma organização em sete grupos, ou seja, os Apoiadores, que são provedores emprestando recursos, como dinheiro, tempo e encorajamento; Fornecedores, que vendem seus serviços e bens materiais; Requladores, incluem agências e os poderes legislativos nos diversos niveis, como o federal, estadual e municipal, impondo regras de conduta; Intemos, que processam os insumos da organizaçāo sendo constituidos por seus funcionários, conselheiros administrativos, etc.; Agentes, que distribuem os 
produtos muitas vezes diretamente aos públicos consumidores, como funcionários, que além de ser público interno, também atuam como agentes e midia de massa; Clientes, principais consumidores diretos do produto e o Público em Geral, considerado consumidores indiretos, incluídos os públicos locais, de massa, concorrentes, etc.

Todos eles estão inter-relacionados, e quando um público especifico passa a ser importante para uma organização, torna-se um mercado-alvo, e a organização inicia um planejamento e uma comunicação de marketing objetivando oferecer seus próprios recursos para fundamentar uma troca.

Nessa relação de troca, embora o pensamento de marketing já esteja consolidado nas empresas de negócios, ele pode ser utilizado igualmente nas demais organizaçōes, principalmente nas de bem-estar público que, por ter uma base financeira garantida e possuir um monopólio de poder, geralmente têm uma visão da orientação de marketing como sendo menos relevante. O que não é verdade, pois a quantidade de apoio público e o tamanho do seu orçamento podem ser diretamente afetados em função da qualidade de seus serviços prestados. 


\subsection{A EVOLUÇÃO DO CONCEITO DE MARKETING}

Durante toda a história da humanidade, o processo de trocas evoluiu sob o ponto de vista econômico, e o homem cresceu e se desenvolveu em um mundo onde os recursos naturais eram abundantes e não considerou que um dia eles poderiam se esgotar.

Com a revoluçāo industrial surgiu a Era da Produção em que até 0 início do século $X X$, não havia o conceito de satisfazer os "desejos" dos consumidores, e os fabricantes direcionavam sua produçāo para atender as necessidades básicas de alimentação, vestuário e bebidas, que era tão alta, que tudo o que se produzia era vendido, sem muitas exigências dos compradores.

Toledo; Santos (1979) observam que as definições de marketing têm se modificado ao longo do tempo em virtude da evoluçāo crescente e da complexidade das sociedades industriais, considerando o caráter multidisciplinar do marketing, como outras ciências voltadas para o estudo e a interpretação do comportamento humano, fazendo com que suas fronteiras teóricas e operacionais estejam sendo continuamente redefinidas, incorporando novas técnicas, conceitos e filosofias de ação.

Segundo Mazzon (1982), a base dessa evolução foi decorrente da Segunda Grande Guerra que propiciou uma revoluçāo 
cientifica, resultando em uma reorientação na metodologia das ciências não físicas, criando uma aproximação e a colaboração de profissionais com formação multidisciplinar, o que resultou em novas abordagens e teorias de novas disciplinas.

No periodo inicial do pós-guerra, Bartels apud Mazzon $(1982)^{2}$ "...definiu esse periodo de interface como de reavaliação $e$ reconceitualização do pensamento de marketing." Dessa forma, as teorias assumem um caráter de serem executadas de forma planificada e entendida à luz de teorias, nas quais houve um esforço de teorizaçāo em campos antes empíricos.

A fertilidade de estudos e trabalhos desenvolvidos levou a uma ampliação das perspectivas dos teóricos de marketing em sua utilização integrando um conjunto de outras disciplinas.

Alguns estudiosos da época sinalizavam e preconizavam que estavam surgindo várias disciplinas que contribuiriam para a construçāo de uma teoria de marketing e defendiam a idéia da criação de uma teoria geral do marketing que deveria ser parte integrante da ciência do comportamento, com um conjunto de proposições relacionadas às atividades de mercado, explicando os mecanismos de ação, relações de interaçōes

\footnotetext{
2 BARTELS, R. Marketing Theory and Metatheory. Homewood: Richard D. Irwin, Inc., 1970, Apud: MAZZON, J. A.; Marketing Social: Conceitos e Perspectivas de Utilizaçăo no Brasil. Revista de Administraçăo - V. 7 - n.4 - p.58, 1982 . p. 6.
} 
funcionais que permitissem previsōes e critérios para o controle da sucessão de fatos mercadológicos.

Os autores fazem uma retrospectiva analisando $\circ$ conhecimento de marketing desenvolvido e observam que nesse período, ele emergiu como uma disciplina acadêmica e um corpo de metodologias de pesquisa de marketing.

A teoria de marketing foi enriquecida com os conhecimentos de outras ciências sociais, como a psicologia, a sociologia, a economia, o que tornou explicativa a ação de um grupo ou de um indivíduo no mercado buscando atender suas necessidades.

O resultado foi um entendimento mais aprofundado da ação empresarial e um progresso contínuo, aprofundando e penetrando cada vez mais no marketing de uma forma multidimensional, procurando casar a teoria dos acadêmicos com os problemas de marketing.

Os autores comentam ainda que em muitas empresas os problemas básicos são decorrentes da falta de integração dos campos funcionais com os da administração, sendo o problema ver o negócio como um sistema operacional, e não como um todo, o que a visão de marketing pode propiciar, de forma holistica, contribuindo com as ciências sociais em sua interação. 
Toledo; Santos (1979) observam que as definições de marketing estavam associadas a uma visão limitada dos seus problemas por terem uma ótica generalizada e tendenciosa de não fazer uma distinção nítida e didática entre a função de marketing, as atividades desempenhadas e a filosofia de ação empresarial, associadas aos conceitos e às técnicas de marketing.

Segundo os autores, existem três dimensōes em que o marketing deve ser considerado, como:

- a função de marketing que engloba um conjunto de meios facilitadores de trocas;

- as atividades de marketing que estão relacionadas com a anterior no exercício e implementação, exigindo a consecução de um conjunto de atividades do processo caracterizadas como administração de marketing, englobando as funçōes clássicas de planejamento, organização, direção e controle;

- e a filosofia do conceito de marketing, espelhando a preocupação das organizações com a filosofia do processo de trocas, destacando o conceito da responsabilidade social do marketing perante a sociedade.

Podemos sintetizar esses conceitos através da figura que segue 


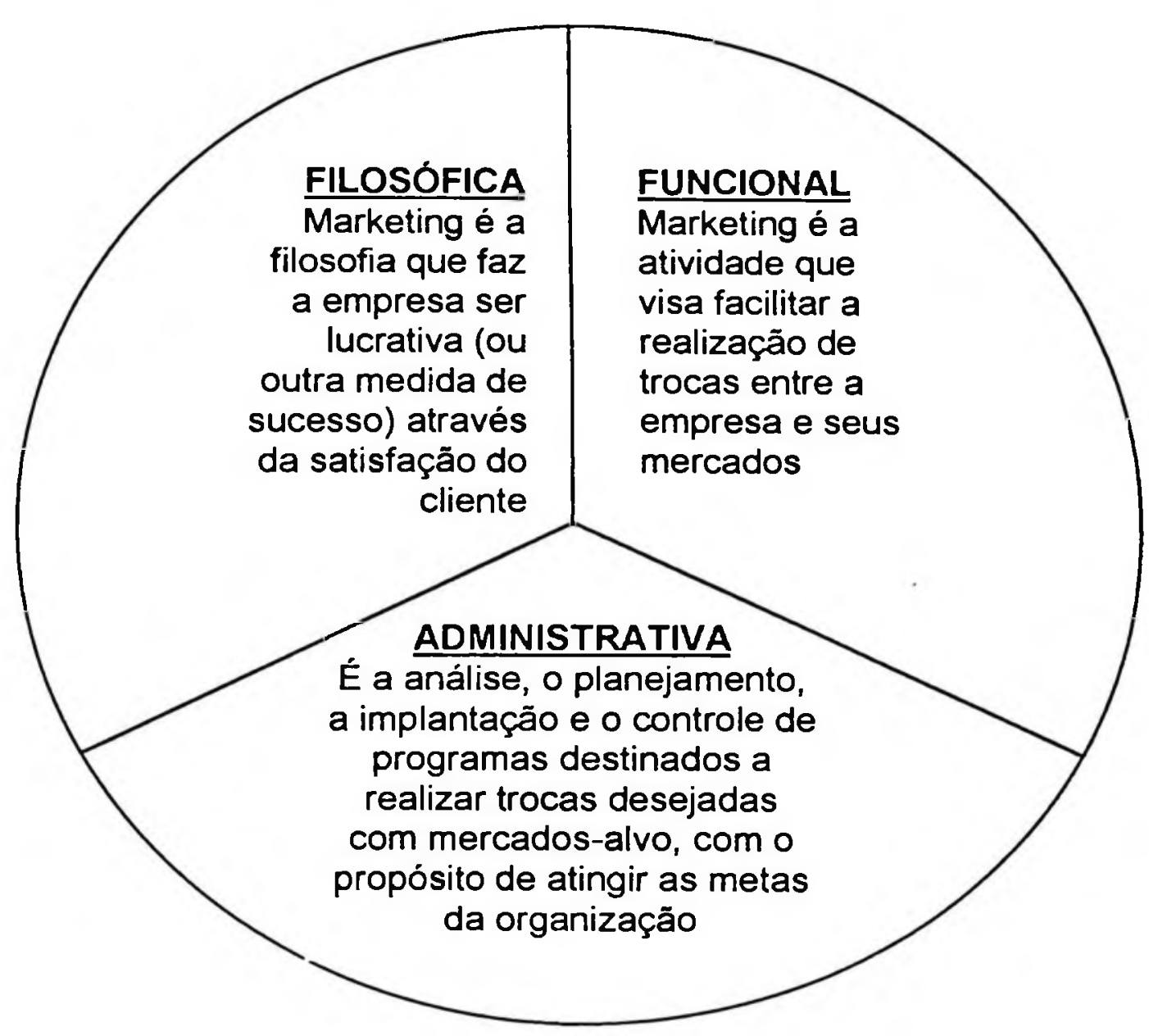

FIGURA 3: As três dimensōes do marketing

Fonte: $\quad$ Adaptado de Toledo; Santos (1979). Toledo(1979 ou 1980) p.40

Os autores observam que o marketing sofreu radicais transformações, e que após os anos 50, o consumidor era valorizado, e a ênfase era dada para o volume de vendas em que a lucratividade ocorria, em função das economias de escala proporcionadas pela produção em massa. 
Com um consumidor exigente e insaciável, o objetivo era vender seus produtos ao máximo, e o marketing deveria fornecer instrumentos necessários para atingir esses objetivos.

Nos anos 50 , os administradores de marketing perceberam que o consumidor deveria ser o centro de suas atençōes e passaram por uma reformulação, sendo que o destaque de vendas enfatizado pelo volume vendido passou para uma orientação de satisfação do cliente. A lucratividade seria uma decorrência de um relacionamento a longo prazo.

Lazer; Kelley (1962) não tratam sobre as contribuições especificas de outras disciplinas, mas procuram estimular o pensamento e a reflexão sobre a aproximação interdiciplinar como resposta a certos problemas de marketing e às áreas funcionais da administração empresarial, bem como suas implicaçōes administrativas e educacionais na extensão das contribuições interdiciplinares para os sistemas de marketing.

Porém, os autores alertam como precaução quanto à integração da descoberta de outras disciplinas com as de marketing. Pois entre os psicólogos, os sociólogos, os antropólogos e os cientistas comportamentais, necessariamente não são unificados alguns conceitos, como os de marketing, e que há correntes e linhas de pensamentos diferentes entre as mesmas áreas. 
A grande contribuição para o marketing das ciências comportamentais consiste no conhecimento que ajuda a resolver e explicar certos fenômenos especificos de marketing.

Com isso o marketing atingiu, enquanto disciplina, em seu desenvolvimento uma fase que pode ganhar uma avaliação crítica e incorporar o desenvolvimento de outras pesquisas e teorias desenvolvidas por outras ciências.

Dessa forma, o conhecimento desenvolvido pelas outras ciências contribui com pesquisas e teorias testadas e estudadas por outros campos, que podem ser somadas e criar novas perspectivas para o campo do conhecimento de marketing, auxiliando no entendimento de alguns conceitos, melhorando nas ferramentas analíticas e aumentando a efetividade das decisōes no marketing. Porém, deve-se tomar uma precaução e avaliar determinados estudos antes de serem utilizados nas técnicas de marketing.

Na visão de Mazzon (1982), a evolução do marketing é atribuída a dois fatores, sendo o conceitual e o de percepção. No primeiro caso, as mudanças ocorrem no conceito de marketing do que é e do que deveria ser, e no segundo, com a introdução de novas idéias e campos de aplicação no marketing. 
Segundo Bartels (1974), esses dois fatores evoluiram em cinco estágios que influenciaram especialmente neste século, sendo caracterizados como:

1. Inicialmente o marketing foi relacionado com a distribuição de produtos e no início da década de 20 , ligado ao processo produtivo, passou a ser entendido como um gerador de economias nesse processo;

2. Marketing no inicio da década de 50 expandiu-se para a administração do processo de distribuição;

3. No final dessa década, o marketing passou a ser visto como um processo social ampliando seu conceito;

4. Durante os anos 60 , além da ótica social o marketing passou a ser visto como um processo societal, por ter funções e responsabilidades interrelacionadas com a estrutura social;

5. Nos anos 70, o marketing passou a ser visto como uma função genérica em que seus principios e ferramentas podiam ser aplicados à qualquer organização.

Nesse último estágio, nota-se uma mudança conceitual na qual o marketing passa a ser visto com uma abordagem inovadora, pois a filosofia de marketing, que antes era aplicada apenas a organizações que visavam o lucro e eram produtoras de bens, modifica seus limites para incluir as empresas que não visam o lucro, configurando as dimensões sociais do marketing. 


\subsection{A AMPLIAÇÃO DO CONCEITO}

Kotler; Levy (1969) publicam um artigo propondo a ampliação do conceito de marketing defendendo a idéia de sua aplicação para organizaçōes sem fins lucrativos, causas sociais, pessoas, idéias, etc. No artigo, eles enfatizam o marketing como uma atividade societal e que vai além das simples vendas de mercadorias.

Os autores consideram que até as organizaçōes sem fins lucrativos possuem ferramentas de marketing, produtos, intermediários e consumidores que necessitam manter-se em constante contato para identificar suas necessidades, e desenvolver produtos que as satisfação, construindo um programa de comunicação que expresse os propósitos da organização.

No artigo, consideram que toda organização produz um determinado produto que pode ser tangivel (físico) ou intangível (serviços), incluindo pessoas através de atividades humanas, idéias e organizaçōes que lidam com vários grupos que tenham interesse em seus produtos, como seus consumidores e fornecedores.

Quanto às ferramentas de marketing, existem preocupaçōes comum tanto entre empresas lucrativas como nas que não visam o lucro, 
como o desenvolvimento de novos produtos partindo das necessidades de seus clientes, as atividades de distribuição, a comunicação e o preço.

Ou seja, o cliente necessita do serviço certo no momento certo e de ser informado sobre a prestação do mesmo, visando atender suas necessidades com um preço compativel ao que foi oferecido e que propicie um equilíbrio no orçamento para manter a manutenção de suas atividades.

Com isso, os autores observam que todas as instituições, como escolas, igrejas, departamentos de polícia e museus possuem produtos e consumidores e utilizam os instrumentos do composto e das atividades de marketing, mesmo que estas não sejam reconhecidas. Eles concluem que nenhuma organização pode evitar o marketing, e que a escolha não é a de utilizá-lo, mas sim de fazê-lo bem.

Luck (1969) contestou essas idéias acreditando que antes de tentar ampliar o foco e os limites para outras áreas que são de difíceis abrangências eticamente, as atividades de marketing deveriam ser melhor exploradas e aprofundadas nas organizaçōes lucrativas, pois as maiores atividades desenvolvidas em sociedade ocorrem em empresas privadas, sendo as responsáveis pela satisfação das necessidades humanas e de seu progresso. 
O autor destaca que o marketing deveria ser melhorado nessas organizações restringindo suas atividades e seu campo de atuação com finalidade lucrativa, na qual a transação em um mercado é caracterizada pela compra e venda.

Em resposta, Kotler; Levy (1969) acusam Luck (1969) de miopia quanto à abrangência verdadeira do marketing. Os autores se baseiam no fato de que o marketing é adequado tanto para as organizaçōes lucrativas como para as sem fins lucrativos, enfatizando o ajuste contínuo da oferta da organização às necessidades dos compradores e não na venda de um produto ou serviço.

Além disso, os autores afirmam que se as organizações sem fins lucrativos tinham uma consciência maior das práticas e conceitos de marketing, no planejamento e execução de suas políticas, poderiam extrair muitos benefícios.

Para Webster (1978), embora o marketing tenha nascido e se criado em um contexto de atividades de negócios e voltado para o lucro, o enfoque do marketing social aplicado ao comportamento fez surgir uma nova compreensão de oportunidades quanto à eficácia aprimorada e variada de organizações. Representando uma conscientização de que as organizações que não visam o lucro também podem ser beneficiadas com os conceitos de marketing e melhorar o discernimento conceitual sobre o marketing visando o lucro. 
O autor observa que Kotler e Levy, ao proporem uma visão mais ampla do conceito de marketing, suscitaram discussōes e criticas, como a de Luck, iniciando uma "...série de propostas que surgiram na literatura de marketing, pedindo e oferecendo um conceito mais amplo de marketing". Webster (1978)

Em sua visão, ele aponta que muitas propostas foram rejeitadas atribuindo ao fato de que havia defensores ansiosos em libertar o marketing das acusaçōes de cumplicidade de algumas ações indesejáveis e suas conseqüências por parte das empresas.

No ano de 1971, Kotler; Zaltman (1971) publicam um artigo com o termo marketing social considerando em sua abordagem 0 planejamento, a implementação e o controle de programas calculados que influenciam a aceitação de idéias e mudanças sociais.

Com as controvérsias surgidas, Kotler (1972) escreve um outro artigo procurando mostrar uma nova visão do marketing, que ele é muito mais complexo e pode ser aplicado em contextos fora do empresarial, como o social. Lembrando que Kotler; Levy (1969) avançaram alargando a visão de marketing com a nova proposta que recebeu muita atenção e polêmica em 1970, na conferência da AMA - American Marketing Association, que foi dedicada a este tema. 
O trabalho de Kotler (1972) aborda três fases de consciência de marketing, suscitando a reflexão de algumas perguntas sobre o conceito genérico de marketing, sugerindo quatro axiomas que contribuem para formação do seu conceito, descrevendo a base para análise, planejamento, organização e controle das tarefas de marketing para sua administração.

Para as três fases da consciência de marketing, são utilizadas as categorias de Reich apud Kotler $(1972)^{3}$ em que a consciência de número 1 é a tradicional de comercialização. Quanto à consciência 2, é mais ampla focando toda organizaçăo que tem um público, e vem ganhando mais adeptos nesse conceito. Já a consciência 3 é mais abrangente, não se preocupando apenas com o público, mas com a sociedade como um todo. E o futuro do marketing depende dessa conscienncia.

A consciência 1 foca a relação de comercialização, na qual o marketing se preocupa com $\circ$ aspecto econômico entre uma troca, os vendedores oferecem produtos/serviços, e os compradores têm poder aquisitivo ou outros recursos para efetuar a troca.

Nessa análise, a abordagem é a transferência de propriedade e a transação de pagamento, na qual tem de haver seis condições básicas para que a transação ocorra, como dois indivíduos ou mais envolvidos, a escassez de um bem, o conceito de propriedade privada

\footnotetext{
${ }^{3}$ REICH, C.A. The Greening of America. New York: Random House. 1970. apud KOTLER, P. A generic concept of marketing, Journal of Marketing; V.36, n.3, april, p.46-54, 1972.
} 
e parte interessada que tem de estar com algo de interesse para o outro, e eles devem estar dispostos a ostentar o bem ou pagamento, sempre focando o conceito de troca econômica.

O autor mostra um contraste entre o marketing tradicional e as atividades sem fins lucrativos que também envolvem uma transferência de recursos sem estar explicitamente relacionada ao pagamento diretamente, mas envolve de alguma forma uma transferência de recursos de uma parte para outra sem que esteja evidente o pagamento entre elas.

A consciência 2 não vê o pagamento como uma condição necessária para definir o dominio da atividade de marketing como na anterior, mas a análise de comercialização e planejamento é pertinente em todas as organizações, produtos e serviços e para um grupo de consumidores intencionais, com ou sem pagamento, e exemplifica como os museus e a policia se relacionam com a atividade.

Nessa abordagem, a consciência substitui o conceito de transações de mercado com o conceito mais amplo de transaçōes de clientes da organização. Sendo que, nessa situação, a pessoa pode identificar uma organizaçāo, um grupo de clientes e produtos amplamente definidos, e não simplesmente pelo conceito de troca econômica, mas vendo a organização de forma mais abrangente.

A consciência 3 é pouco visivel e não vê a comercialização e a tecnologia limitadas às transaçōes de uma organizaçāo com seu grupo de 
clientes, mas toda sua administração pode se ocupar não apenas comercializando atividades com seus clientes, mas também com todos os outros públicos em seu ambiente, passando por um enfoque institucional.

A administração, nesse estágio de consciência, é voltada para organização, provedores, empregados, Governo, público em geral, agentes, enfim, todos os "públicos-chave" para seu negócio, na tentativa de se relacionar nāo só com seu público consumidor. A comercialização está especificamente preocupada em como são criadas as transações, estímulos e facilidades em um conceito mais genérico de marketing.

Kotler (1972) desenvolve o conceito genérico de marketing, partindo de quatro axiomas, suas implicações como proposição de comercialização e do que não é comercializado, assim temos os axiomas de forma resumida:

Axioma 1: O marketing envolve duas ou mais unidades sociais, consistindo em um ou mais atores humanos.

- As unidades sociais podem ser individuos, grupos, organizaçōes, comunidades ou naçōes.

Axioma 2: Pelo menos uma das unidades sociais está buscando uma resposta especifica de uma ou mais das outras unidades que concernem a algum objeto social. 
- A unidade social que busca a resposta é chamada de especialista em marketing, e a unidade social cuja resposta é buscada é chamada de mercado.

- Objeto social pode ser um produto, organização, pessoa, idéia, etc.

- A resposta buscada no mercado está ligada ao comportamento do objeto social. As respostas procuradas são relacionadas à compra, adoção, uso, consumo, ou as negativas deles/delas. E o que pode responder são os chamados compradores adotantes, usuários, consumidores, clientes ou apoios.

- O especialista em marketing normalmente fica atento para saber se está vendendo a resposta específica.

- A resposta buscada pode ser esperada em uma corrida pequena ou longa

- A resposta tem valor ao especialista em marketing.

- O marketing mútuo descreve um caso em que duas unidades sociais buscam uma resposta simultânea.

Axioma 3: A probabilidade de resposta do mercado não é fixa.

- A probabilidade que o mercado produzirá a resposta desejada é chamada de probabilidade de resposta do mercado.

- A probabilidade de resposta do mercado é maior que zero, quer dizer que o mercado é capaz de produzir a resposta desejada.

- A probabilidade de resposta do mercado é menos que 1 , quer dizer, o mercado não é compelido para produzir a reposta desejada interiormente.

- A probabilidade de resposta do mercado pode ser alterada por ações de marketing. 
Axioma 4: Marketing é a tentativa de produzir a resposta desejada criando e oferecendo valores para o mercado.

- O especialista em marketing assume que a resposta do mercado será voluntária.

- A atividade essencial de marketing é a criação e a oferta de valor. $O$ valor é subjetivamente o ponto de vista do mercado.

- O especialista em marketing cria e oferece, facilitando a oferta de valor.

- O especialista em marketing utiliza os meios do marketing para escolher as ações que são calculadas para produzir a resposta desejada no mercado.

Em resumo, Kotler (1972) procura examinar em seu artigo o debate entre a comercialização e a aplicação em outras áreas nas quais as organizações tentam relacionar os clientes a outros públicos, criando três consciências, e com isso, em seu raciocínio, demonstra que qualquer organização pode ampliar sua atuação, não apenas voltada para o cliente comercial, mas de forma mais abrangente, utilizando o conceito de troca de valores, que pode ser aplicado em outras unidades sociais.

A concepção mais ampla do marketing pode ser chamada de marketing genérico, que leva a uma visão estrutural de marketing, partindo de quatro axiomas:

- Axioma 1: comercialização envolve duas ou mais unidades sociais. 
- Axioma 2: pelo menos uma das unidades sociais está buscando uma resposta especifica de uma ou mais unidades que concernem a algum objeto social.

- Axioma 3: a probabilidade de resposta do mercado não é fixa

- Axioma 4: o marketing oferece valores para o mercado.

Os axiomas e suas implicações são fatores que determinam o que constitui um processo de marketing.

O marketing genérico tem reflexos em empregados, provedores, agentes, consumidores, públicos especiais, gerais, Governo, concorrentes, produtos, serviços, pessoas, lugares e idéias, enfim, em âmbito comercial, político, social, religioso, cultural e organizacional.

O marketing é visto de forma mais ampla aplicado às organizações que não visam o lucro. E em organizações que visam o lucro, é agregado o conceito de responsabilidade social, sendo que os especialistas em marketing enfrentam as mesmas tarefas em todos os tipos de organização, como análise de mercado, análise de produto, tarefas de planejamento, distribuição e promoção, objetivando estimular a motivação. 0 principal dessas tarefas é o controle resultando em medidas e custos.

Segundo o autor, o marketing genérico é uma lógica disponivel para todas as organizaçōes que enfrentam problemas de resposta ao mercado. Sua aplicação, sob um ponto de vista de marketing para um 
problema especifico, leva a uma lógica de comercialização. A experiência e os conceitos de comercialização adicionados à lógica fazem um profissional de marketing adquirir competencia que the permite interpretar os problemas e construir as estratégias de marketing de um modo efetivo.

Acreditando na proposta de ampliar o conceito de marketing desde que seja testado em situações reais comprovando sua utilidade, Enis (1973) publica um artigo objetivando aprofundar e estimular o pensamento e a discussão crítica do marketing, propondo algumas sugestōes e delineando limites que deveriam ser respeitados, enfatizando que as transaçōes que não pudessem ser medidas com precisão deveriam ser excluidas .

Em seu trabalho, Enis (1973) sugere que o aprofundamento do conceito de marketing deveria envolver outros profissionais, pesquisadores, acadêmicos, administradores de marketing, divulgando estudos e documentos e especificando de forma clara a metodologia, para o uso potencial em tomadas de decisão em planos micro e macro com detalhada autocritica, o que possibilita um retorno dos leitores.

No contexto das discussões, Hunt, (1976) abre um debate sobre as controvérsias que nas últimas três décadas obscureceram a literatura de marketing, questionando se "o marketing é uma ciência?", em um artigo publicado. 
O autor lembra que o tema foi debatido e estudado por escritores eminentes e que a discussão ampliou o conceito de marketing sobre sua natureza nos anos 50 e 60, quando a controvérsia foi reduzida desde então, porém de forma aparente. As caracteristicas essenciais entre o marketing e a ciência são radicalmente diferentes.

Em sua análise, Hunt (1976) aborda a natureza e o escopo do marketing visando apresentar soluções sobre a controvérsia de ser ou não uma ciência e sua verdadeira natureza, assim, avalia definições elaboradas pelos vários autores desde a do AMA - American Marketing Association até a de Kotler e Zaltman (1971).

O autor observa que a partir das idéias de Kotler e Levy (1969) quanto ao conceito ampliado de marketing, ainda havia lacunas e uma falta de visão integrada sobre vários aspectos do marketing.

Em seu artigo, Hunt (1976) desenvolve um modelo conceitual na esfera do marketing que utiliza para analisar três aspectos, sendo:

- a aproximação do estudo de marketing

- a "natureza do marketing" e suas controvérsias

- o debate da ciência e do marketing. 
O autor apresenta o modelo que Kotler propôs em 1972 na conferência da AMA, sugerindo a classificação dos fenômenos de marketing em três dimensões conceituais considerando as organizações lucrativas e as não lucrativas; visões micro e marco e positiva e normativa, conforme tabela 1. 


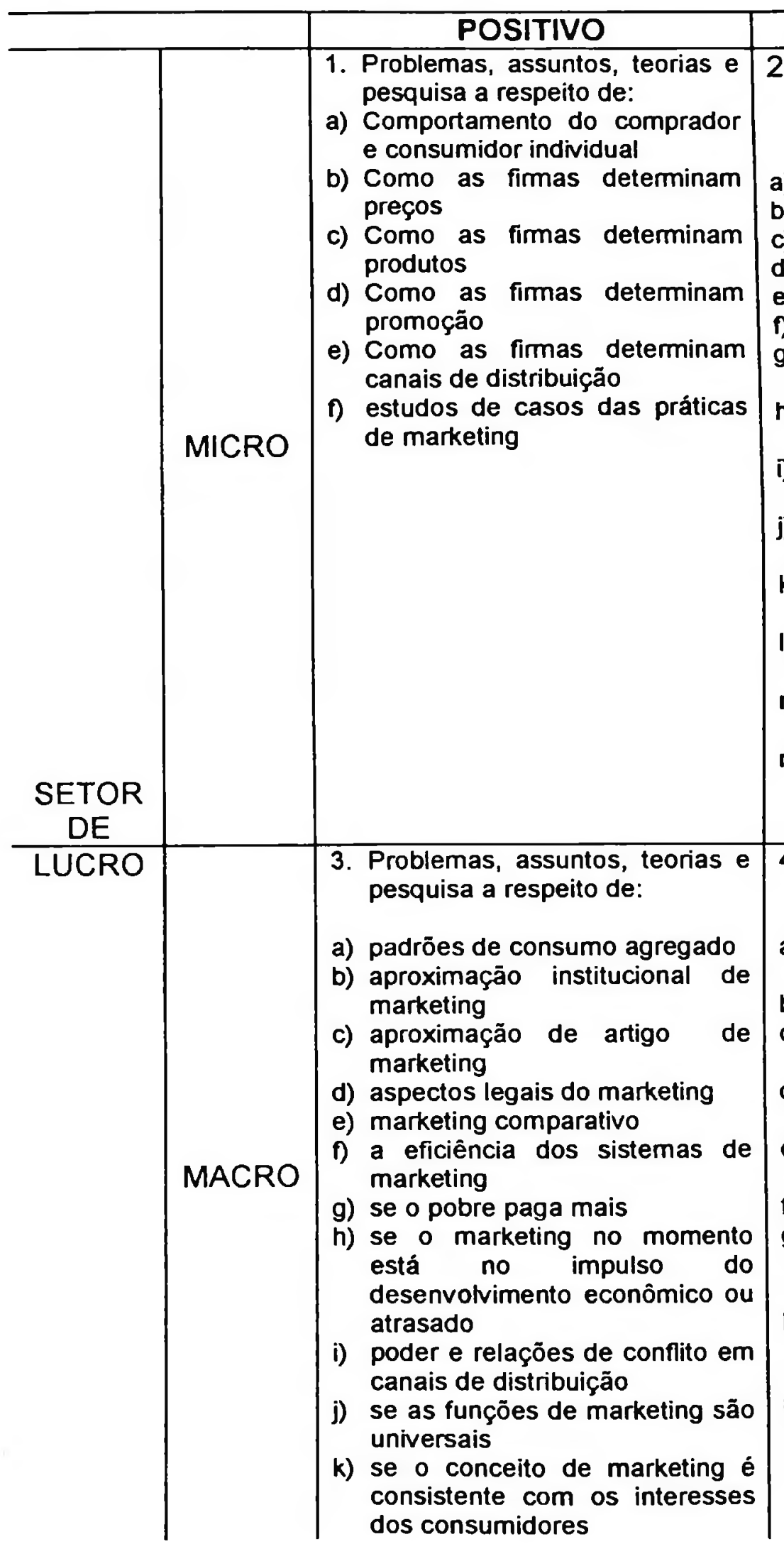

NORMATIVO

2. Problemas, assuntos, modelos normativos, e pesquisa a respeito de como as firmas deveriam:

a) determinar o marketing mix

b) tomar decisões de preço

c) tomar decisōes do produto

d) tomar decisōes de promoções

e) tomar decisōes de embalagem

f) tomar decisōes de compra

g) tomar decisōes de marketing internacional

h) organizar seus departamentos de marketing

i) controlar os esforços de marketing

j) planejar suas estratégias de marketing

k) aplicar teoria nos sistemas de marketing e seus problemas

I) administrar estabelecimentos de varejo

m) administrar estabelecimentos por atacado

n) implementar 0 conceito de marketing

4. Problemas, assuntos, modelos normativos e pesquisa a respeito de:

a) como o marketing pode ser mais eficiente

b) se a distribuição custa muito

c) se anunciar é socialmente desejável

d) se a soberania do consumidor é desejável

e) se simular a demanda é desejável

f) se o pobre deveria pagar mais

g) que tipos de leis e regulamentaçōes são ótimas para o marketing

h) se os sistemas verticais de marketing são socialmente desejáveis

i) se 0 marketing deveria ter responsabilidades sociais especiais

Fonte: Adaptado de HUNT, S. D. The nature and scope of marketing.

Journal of Marketing, v. 40, n.3, p.17-28, july, 1976. 
TABELA 1: O escopo de marketing

\begin{tabular}{|c|c|c|c|}
\hline & & POSITIVO & NORMATIVO \\
\hline $\begin{array}{c}\text { SETOR } \\
\text { SEM }\end{array}$ & MICRO & $\begin{array}{l}\text { 5. Problemas, assuntos, teorias e } \\
\text { pesquisa a respeito de: } \\
\text { a) os consumidores que compram } \\
\text { bens públicos } \\
\text { b) como as organizaçōes sem } \\
\text { lucro deteminam preços } \\
\text { c) como as organizaçōes sem } \\
\text { lucro determinam produtos } \\
\text { d) como as organizaçōes sem } \\
\text { lucro determinam promoção } \\
\text { e) como as organizaçōes sem } \\
\text { lucro determinam canais de } \\
\text { distribuição } \\
\text { f) estudos de casos de bens } \\
\text { públicos }\end{array}$ & $\begin{array}{l}\text { 6. Problemas, assuntos, modelos } \\
\text { normativos e pesquisa a } \\
\text { respeito de como as } \\
\text { organizaçōes sem lucro devem: } \\
\text { a) determinar o marketing mix } \\
\text { (marketing social) } \\
\text { b) tomar decisōes de preço } \\
\text { c) tomar decisōes do produto } \\
\text { d) tomar decisōes de promoçōes } \\
\text { e) tomar decisōes de embalagem } \\
\text { f) tomar decisões de compra } \\
\text { g) tomar decisōes de marketing } \\
\text { internacional } \\
\text { h) organizar seus esforços de } \\
\text { marketing } \\
\text { i) controlar os esforços de } \\
\text { marketing planejar suas estratégias de } \\
\text { j) planej } \\
\text { marketing } \\
\text { k) aplicar teoria nos sistemas de } \\
\text { marketing e seus problemas }\end{array}$ \\
\hline LUCRO & MACRO & $\begin{array}{l}\text { 7. Problemas, assuntos ,teorias e } \\
\text { pesquisa a respeito de: } \\
\text { a) estrutura institucional para bens } \\
\text { públicos } \\
\text { b) se os anúncios em televisão } \\
\text { influenciam decisões } \\
\text { c) se o serviço público anunciado } \\
\text { influencia o comportamento (por } \\
\text { exemplo, 'fumo e bebida") } \\
\text { d) se os sistemas de distribuição } \\
\text { existentes para bens públicos } \\
\text { são eficientes } \\
\text { e) como são reciclados os bens } \\
\text { públicos }\end{array}$ & $\begin{array}{l}\text { 8. Problemas, assuntos, modelos } \\
\text { normativos e pesquisa a } \\
\text { respeito de: } \\
\text { a) se a sociedade deveria permitir } \\
\text { que os políticos sejam } \\
\text { vendidos" como pasta de } \\
\text { dentes } \\
\text { b) se a demanda para bens } \\
\text { públicos deveria ser estimulada } \\
\text { c) se "baixo conteúdo informativo, } \\
\text { anúncio político é socialmente } \\
\text { desejável" (por exemplo 10 } \\
\text { segundos "spof" comercial) } \\
\text { d) se para o Exército norte- } \\
\text { americano. deveria ser } \\
\text { permitido anunciar recrutamento }\end{array}$ \\
\hline
\end{tabular}

Fonte: Adaptado de HUNT, S. D. The nature and scope of marketing.

Journal of Marketing, v. 40, n.3, p.17-28, july, 1976.

Observando a tabela de Hunt (1976), nota-se como pode ser extenso o escopo de marketing, e ele conceitua que micro e macro sugerem uma classificação baseada em nivel de agregação. 
A dimensão micro estaria relacionada com as atividades de marketing de unidades individuais, normalmente organizações individuais e unidades de consumo, domicílios ou consumidores. A dimensāo macro estaria relacionada a um nivel mais elevado de agregação, usualmente sistemas de marketing ou grupos de consumidores.

Segundo Hunt (1976), a dicotomia Positiva/Normativa fornece categorias segundo um foco de análise descritivo ou prescritivo. O marketing positivo adota perspectiva de descrever, explicar, predizer e compreender as atividades, processos e fenômenos de marketing que existem no mundo real. Essa perspectiva prende-se a "o que é". Em contraste, o marketing normativo adota a perspectiva de prescrever o que as organizações de marketing e os individuos devem fazer ou que tipo de sistemas de marketing a sociedade deve ter. Ou seja, essa perspectiva prende-se a "o que deve ser."

Em sua análise, o autor amplia a tabela com seu quadro comparativo com questões que no contexto geral poderiam ser consideradas como uma ciência, por isso tem provocado tanta confusão, ressaltando que a percepção da natureza do marketing era variada e que havia um consenso na aplicação do conceito nas organizaçōes sem fins lucrativos. Apesar das argumentações favoráveis, em sua abordagem discorda em considerar o marketing uma ciência. 
Laczniak; Michie (1979) publicaram um artigo analisando o conceito ampliado do marketing sob a ótica de suas implicações para a ordem social. Na visão dos autores, o conceito ampliado de marketing poderia diminuir a desordem social entendida como a quebra do equilibrio que existe entre fenômenos, idéias, práticas, organizações e sociedade.

Em seu trabalho, Laczniak; Michie (1979) fazem críticas observando que o termo marketing nāo deveria ser empregado fora dos limites da área de negócios, devido às limitações e dificuldade de mensuração de suas atividades em definir o "bom e o mau" marketing em termos de moralidade ou necessidades sociais.

Outras limitações seriam a implementação do marketing para organizações que não visam o lucro de forma abusiva, que poderia trazer problemas e conseqüências para a área de marketing em geral, e a relação de troca não se preocuparia com seu conteúdo, mas apenas com a própria troca.

Preocupados com as dimensões éticas do marketing social, Laczniak et al. (1979) no mesmo ano elaboraram uma pesquisa junto a professores de ética, membros da Sociedade de Estudo Psicológico de Questões Sociais, assinantes do Jomal de História Econômica, praticantes de marketing e membros da AMA - American Marketing Association, focando as implicações éticas da ampliação do conceito de marketing. 
Os autores alertam, na conclusão do estudo, que o marketing social aplicado a campanhas públicas deve ser utilizado com um certo cuidado, porque ao mesmo tempo que traz inúmeros benefícios, traz conseqüências de ordem ética e social, ressaltando que não deveria haver nenhuma forma de controle social, seja ele por parte do Governo ou por associações profissionais.

Além disso, os autores enfatizam o aspecto ético que relaciona o programa de marketing com as idéias promovidas, e os profissionais de marketing deveriam dividir a responsabilidade pelo impacto gerado de qualquer programa por eles implementado.

No raciocínio dos autores, estava embutida a possibilidade de haver uma conotação de manipulaçāo e controle social em relação à ampliação do conceito de marketing, por isso eles tinham uma preocupação nitidamente focada no caráter ético de sua utilização.

Durante a década de 70 , nas discussões do conceito de marketing social, formaram-se duas correntes de pensamento entre os diversos autores, sendo que a primeira, através de uma dimensão social contrapondo-se à comercial, enfatizava os princípios e as práticas de marketing em uma abordagem operacional aplicada a produtos e serviços lucrativos de forma abrangente, aplicados também em programas sociais e na promoção de idéias e causas. 


\begin{abstract}
A segunda corrente formada relacionava o conceito de marketing social com as conseqüências e impactos das práticas de marketing sobre a sociedade. Mazzon (1982) observa que:
\end{abstract}

"....o conceito de marketing social - entendido como marketing de idéias, causas e programas sociais - deve ser distingüido do conceito de "marketing societal"- entendido como as implicações a longo prazo sobre a sociedade das práticas de marketing e também do conceito de marketing para organizações que não têm finalidade lucrativa - dado que essa característica por si só não garante que seus programas sejam ampla e reconhecidamente de natureza social."

Assim, visando sintetizar o que havia ocorrido nos últimos 10 anos, na proposta de ampliação do conceito de marketing, Fox; Kotler(1980) escreveram um artigo discutindo e analisando o que era marketing social, baseados na teoria e em experiências empíricas. Em sua abordagem, discutem quando e em quais situações deveriam ser aplicadas, comentaram sobre as barreiras e críticas de sua penetração e apontaram o futuro do novo conceito.

Duhaime et al. (1985) abordam a temática do marketing social para o Terceiro Mundo em artigo focando como poderiam ser melhoradas as condiçōes de vida nesses paises. Os autores focam que a 
maioria das pessoas desses paises nāo tem benefícios sociais básicos, sendo que a maioria das pessoas vive na pobreza, sem habitação e em condiçōes precárias de saúde.

$\mathrm{Na}$ visão dos autores, o problema central do mundo econômico era como auxiliar o desenvolvimento dos países subdesenvolvidos. Assim, eles apresentaram um modelo visando subsidiar o planejamento de programas sociais voltados para o Terceiro Mundo agregando condições ambientais que pudessem influenciar o sucesso dos mesmos.

No modelo desenvolvido pelos autores, as condições estão relacionadas com aspectos político-administrativos, econômicos, comunicativos, sociais e culturais, nos quais as mudanças podem precipitar circunstâncias que ocorrerão em função da motivação social, criando ações especificas do agente de mudança. O quadro a seguir ilustra esse processo. 


\section{CONDIÇÕES FACILITADORAS}

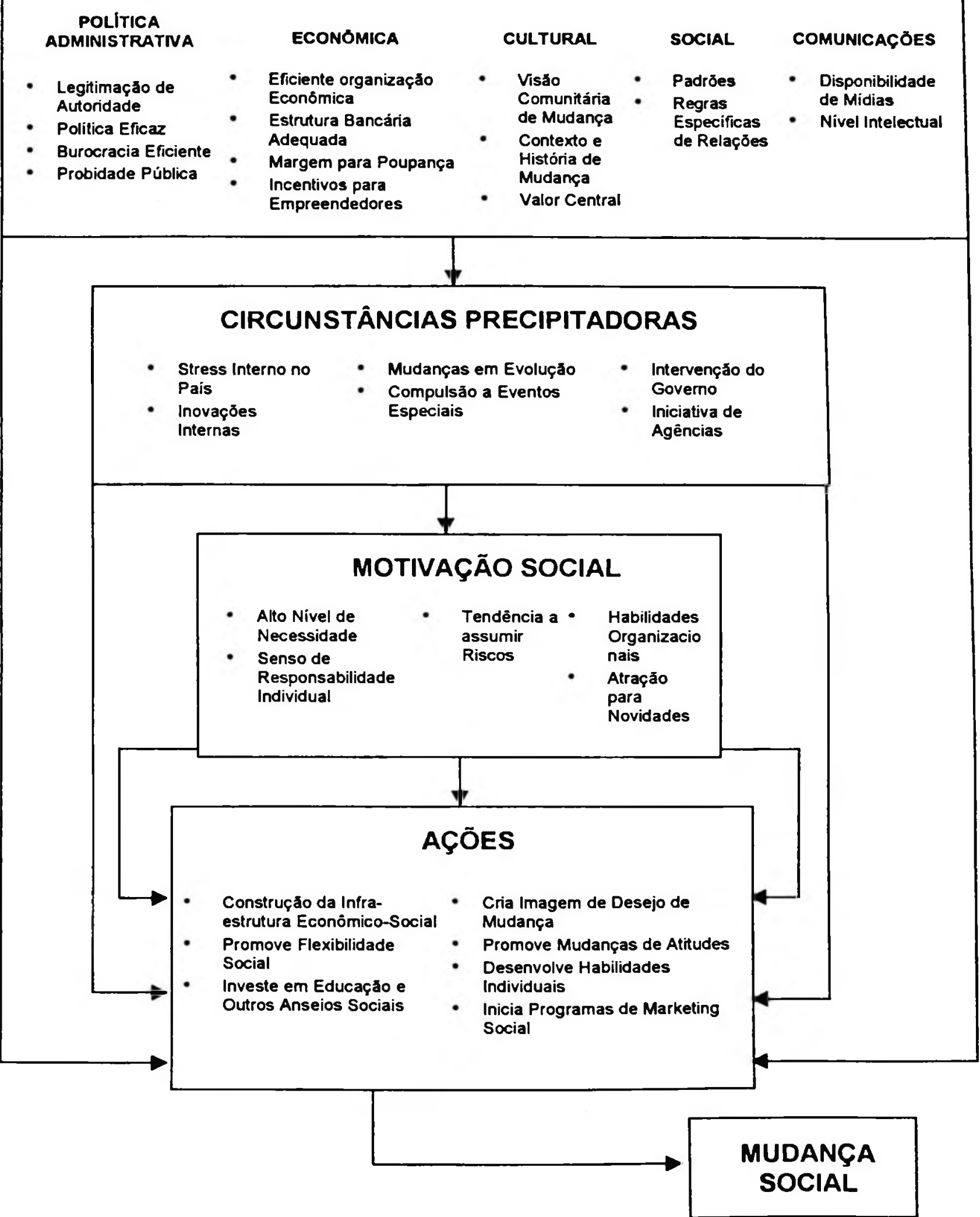

FIGURA 4: Modelo de fatores que conduzem às mudanças sociais

Fonte: $\quad$ Adaptado de Duhaime et al,1985. p.9 
Após varias discussões, observa-se que o marketing social pode ser definido, conforme Kotler; Zaltman (1971), como:

“O marketing social é o projeto, a implementação e o controle de programas que procuram aumentar a aceitação de uma idéia ou prática social num grupo-alvo. Utiliza conceitos de segmentação de mercado, de pesquisa de consumidores, de configuração de idéias, de comunicações, de facilitação de incentivos e a teoria da troca a fim de maximizar a reação do grupo-alvo."-

Para os objetivos deste trabalho, adotou-se esta conceituação.

\subsection{A IMPORTÂNCIA DO AMBIENTE SOCIAL NA FILOSOFIA E DECISÕES DE MARKETING}

As origens do marketing vêm do fato de que o homem tem desejos e necessidades criando um estado de desconforto nas pessoas que, na visão de Kotler (1988), se resolve através da aquisição de objetos que satisfaçam essas necessidades e desejos. 
O marketing convencional envolvia a oferta de produtos e serviços que satisfaziam às necessidades e aos desejos dos consumidores. Bennett; Kassarjian (1975) observam em seus estudos o comportamento do consumidor. Desde o início das trocas de bens e serviços entre vendedores e compradores, a liberdade de escolha do consumidor é relativa pois o sucesso de toda atividade econômica depende da produção de bens e serviços que o comprador considere apropriados.

Na opinião de Kotler(1988), o marketing significa trabalhar com mercados em uma tentativa de realizar trocas em potencial com o objetivo de satisfazer as necessidades e desejos humanos, ou seja, a administração de marketing é administrar a demanda.

Na visão de Rocha(1994), "O marketing parte da idéia de que a demanda provém de um conjunto de consumidores cujas preferências são distintas entre si, e de que a oferta é composta por um conjunto de fabricantes cujos produtos apresentam certo grau de dissimilaridade. 0 marketing procura obter o melhor acoplamento possivel entre segmentos da oferta e da demanda."

Rocha (1994) diz ainda que o mercado é dinâmico e deve-se ajustá-lo de forma permanente, para não perder sua posição que é ameaçada por mudanças ambientais, ações dos concorrentes e, principalmente, por comportamento dos consumidores, cabendo ao marketing a tarefa de ajustes. 
As mudanças ambientais sāo fatos relacionados à economia, política e legislação, já as dos concorrentes, como estudado por Porter; Linide (1995), são ações da concorrência que forçam as empresas a procurar um novo ajustamento, baseadas na entrada e saída de concorrentes, lançamentos de novos produtos e introdução de novas práticas gerenciais, etc. Quanto às mudanças no comportamento dos consumidores, são muitas vezes o resultado de adaptações às mudanças ambientais.

São inúmeras as definiçōes de marketing existentes, mas não se chegou a uma totalmente consagrada. Kotler contribui avançando com o conceito Societal do marketing que considera o bem-estar da sociedade a longo prazo. Ottman (1994) traz uma visão de qualidade de vida para os consumidores com o "marketing verde", pelo impacto que os produtos têm no meio ambiente influenciando nas decisões de compra.

A autora suscita novas reflexões que requerem estratégias mais elaboradas e propõe novos desafios relacionados com a forma da empresa ver o "verde" e desenvolver produtos que agridam menos o meio ambiente e, nessa linha, comunicar com credibilidade sua iniciativa junto aos consumidores, melhorando sua imagem institucional, e até utilizando-a como posicionamento mercadológico.

Em paises desenvolvidos, a pressão dos consumidores está forçando as empresas a implementar programas de reciclagem que apontam 
como uma solução para reduzir a utilização de matérias-primas sem risco de esgotamento dos recursos não renováveis, trazendo uma economia maior nos processos produtivos e redução de energia.

Com isso, a responsabilidade das empresas não acaba com o ato da venda, que antigamente preocupavam-se apenas com o desempenho do produto e preço, mas sim com o impacto ambiental que provoca o pós-consumo.

Em uma pesquisa nacional sobre "O que o brasileiro pensa sobre o meio ambiente, desenvolvimento e sustentabilidade", coordenada pelo MMA - Ministério do Meio Ambiente, dos Recursos Hídricos e da Amazônia Legal (O que o brasileiro..., 1997), que compara dados obtidos em 92 com os de 97 , apontou-se que:

Apesar de o meio ambiente não aparecer entre as principais preocupações dos brasileiros, como desemprego, saúde, educação, segurança e moradia, ocupa o $7^{\circ}$ lugar nas preocupações das pessoas com maior nivel educacional e renda, e nas de pessoas com menor escolaridade e renda, esta posição cai para $11^{\circ}$ lugar.

A pesquisa revelou que para reduzir a poluição de origem industrial, mais da metade dos brasileiros acredita que o Governo deve aumentar a fiscalização e que o Congresso deve votar leis mais rigorosas; 
$35 \%$ são a favor de incentivos às indústrias, tais como descontos nos impostos, para que invistam em preservação do Meio Ambiente.

Em uma pesquisa realizada por Santos; Mazzon (1995), sobre os "Desafios para a internalização da Gestão Ambiental nas Empresas: um estudo exploratório no Brasil", os autores detectaram que o Governo é uma das principais entidades que mais deveriam se responsabilizar pelo combate aos problemas ambientais. Em porcentagem, conforme segue no quadro 1.

\begin{tabular}{|l|c|}
\hline \multicolumn{1}{|c|}{ ENTIDADES } & $\%$ \\
\hline GOVERNO & 86,3 \\
\hline ASS. ECOLOGICAS & 74,5 \\
\hline INDÚSTRIAS & 55,1 \\
\hline
\end{tabular}

Quadro 1: Entidades que mais deveriam se responsabilizar pelo combate aos problemas ambientais.

Fonte: $\quad$ Adaptado de Santos, R C; Mazzon,.(1995)

Os autores também identificaram os tipos de indústrias que mais prejudicam o meio ambiente e são as mais poluidoras, evidenciando o contexto de atitudes dos consumidores brasileiros em termos daquilo que os preocupam, observando que para o desenvolvimento de ações por parte das empresas, deve considerar esse contexto, conforme segue quadro 2. 


\begin{tabular}{|l|c|}
\hline \multicolumn{1}{|c|}{ ATIVIDADES } & $\%$ \\
\hline EXTRAÇĀO DE MADEIRA & 62,9 \\
\hline INDÚSTRIA QUIMICA & 60,9 \\
\hline INDÚSTRIA DE PAPEL E CELULOSE & 40,4 \\
\hline INDÚSTRIA PETROLIFERA & 31,4 \\
\hline EXTRAÇÃO DE MINERAIS & 26,0 \\
\hline INDÚSTRIA METALÚRGICAUSIDERÚRGICA & 23,6 \\
\hline INDUUSTRIA AUTOMOBILISTICA & 12,6 \\
\hline INDÚSTRIA PESQUEIRA & 11,3 \\
\hline INDUSTRIA FARMACÉUTICA & 9,0 \\
\hline AGRICULTURAILAVOURA & 6,4 \\
\hline INDUUSTRIA TÉXTIL & 4,3 \\
\hline PECUARIA & 2,1 \\
\hline INDÚSTRIA ELETROELETRŌNICA & 1,7 \\
\hline OUTRAS ATIVIDADES & 2,4 \\
\hline
\end{tabular}

Quadro 2: Tipos de indústrias que mais prejudicam o meio ambiente (\%) Fonte: $\quad$ Adaptado de Santos, R C; Mazzon, (1995).

Vandermerwe; Oliff (1991) recomendam como solução que as práticas produtivas e de consumo sejam passiveis de reciclagem plena dos recursos naturais, sendo necessária uma mudança de paradigma de produção e consumo, em funçāo da utilização dos escassos recursos naturais com tendência de esgotamento.

Dessa visão, Santos R C (1993) complementa analisando esses autores que partem de uma visão de modelo industrial clássico, no qual os estágios são: produção-> compra-> uso-> e descarte, e recomendam o procedimento de reconsumo. Na visão antiga, apesar de já haver uma preocupação com a reciclagem, em muitos casos, era mais barato descartar o produto e a embalagem do que consertar ou preocuparse com o destino que ela tomaria ao ser descartada. 
Pressionadas pelos consumidores sobre a produção industrial, as empresas começaram a mudar de paradigma, e a questão de reconsumo preocupava-se com um consumo mais contínuo e duradouro, reaproveitando e otimizando todos os recursos e componentes na elaboração de um produto, objetivando realimentar o processo produtivo, atribuindo uma grande importância às questões ambientais que apontam como um novo paradigma.

O novo modelo não e mais linear como o antigo (produção-> compra-> uso-> descarte), ele é mais complexo. Ao invés de descartar o que gera poluição e os residuos sólidos, após o uso, procura-se prolongar o produto, consertá-lo, criar situações de reutilização e reaproveitamento e, em última instância, reciclar até chegar em um estágio em que não possa mais ser reciclado, existindo a possibilidade de ser utilizado como material para fonte de energia.

Santos R C (1993) em seu trabalho e análise propõe quatro alternativas que podem propiciar o reaproveitamento total, são elas:

- Reabastecimento - que envolve a restauração ou recondicionamento de produtos, como oferecer refil de embalagens em algumas situações, ou consertar determinados componentes em outras. $\mathrm{O}$ grande desafio nessa alternativa é o de rejuvenescer um produto mantendo atualizada a tecnologia e os materiais empregados, sem tornar a versão anterior obsoleta. 
- Reutilização - ou reaproveitamento da embalagem do produto. Há empresas que buscam soluçōes criativas e inovadoras. Para reduzir custos, exploram esse potencial em embalagens de seus produtos, envolvendo seus fornecedores na revisão de esquemas de entrega e insumos utilizados.

- Reprocessamento - de produto ou suas embalagens, envolve a reciclagem parcial em total de insumos importantes, como vidro, alumínio de refrigerantes e cerveja, papéis, etc.

- Reutilização em novas formas - É o aproveitamento total ou parcial de um produto ou embalagem que é reciclada, processada e se transforma em novos itens, como objetos plásticos que sāo reprocessados e viram vasos, pregadores, etc.

Santos R C (1993) ressalta que o reconsumo impacta diretamente nas organizações ocorrendo em nivel interno e externo, nos quais os funcionários (internamente) devem assimilar novos valores de conscientização em seu cotidiano, através de atitudes, práticas e procedimentos desempenhados, reconhecendo a importância das questōes ambientais. Dessa forma, em estágio posterior, podem apresentar suas propostas de produtos e serviços aos segmentos de mercado preocupados com essas questões. 
No processo de globalização e com a pressão dos consumidores, as empresas têm buscado tornar-se mais competitivas e desenvolver produtos "ecologicamente corretos". Para isso, busca capacitar seus funcionários.

\subsection{A VARIÁVEL AMBIENTAL NA ESTRATÉGIA ORGANIZACIONAL}

Embora as empresas estejam tomando consciência de suas responsabilidades ambientais e estejam se empenhando em aprimorar seus recursos, ainda não existem treinamentos formais nessa área, e as empresas estão se organizando de acordo com sua realidade e tentando implementar programas junto a seus funcionários.

Donaire (1995), em sua obra afirma que:

"O desempenho de uma organização está fortemente associado à qualidade de seus recursos humanos. Se uma empresa pretende implantar a gestão ambiental em sua estrutura organizacional, deve ter em mente que seu pessoal pode transformar-se na maior ameaça ou no maior potencial para que os resultados esperados sejam alcançados. 
Assim, a área ambiental deve desenvolver com a área de Recursos Humanos intenso programa de conscientização, visto que a atividade de meio ambiente inicia-se $e$ concretiza-se alterando o comportamento das pessoas que a integram.

Como o público pode acreditar na boa intenção da empresa em relação ao meio ambiente se o pessoal interno não estiver convencido e motivado para contribuir de forma positiva na questão ambiental?

Se os trabalhadores não estiverem engajados nesse objetivo, o resultado será medíocre. Se a força de trabalho estiver comprometida e mentalizada para a idéia da gestão ambiental, haverá uma melhora contínua nos indices de qualidade ambiental da empresa."

Dessa forma, propõe em sua obra a integração do conhecimento ambiental em programas de treinamento e em outras áreas de especialização, integrando a empresa como um todo.

O treinamento nessa linha deve desenvolver habilidades gerenciadas no processo de tomada de decisão, encorajando os funcionários a formular e implementar açōes considerando suas conseqüèncias ambientais e sua repercussão junto à comunidade. 
Da mesma forma, deve incentivar e apoiar a comunicação com seus subordinados enfatizando as questōes ambientais nos aspectos relacionados à economia de energia e redução de custos.

Além desses ambientes internos, como mobiliário e instalações, devem propiciar aos funcionários um ambiente mais agradável para que possam estar mais estimulados.

Donaire ainda propõe que nos programas de treinamento ambiental, a orientação inclua noçōes de auditoria ambiental, auditoria energética, marketing verde, administraçāo de resíduos e reciclagem, responsabilidade social da empresa, comunicação e participação nas questões ambientais, tecnologia limpa, etc.

E finaliza que qualquer que seja a orientaçāo do treinamento, ele não deve se restringir a aulas formais, mas incluir visita às. fábricas, e enfatiza que a participação de setores da sociedade, como ONG's, é fundamental nos programas de treinamento para se obter uma compreensão mais abrangente de todas as variáveis que integram o contexto ambiental na organização.

As relações de organização do trabalho e estrutura da função têm de ser reavaliadas. Pois com essa nova postura que causa impacto de responsabilidade juridica e financeira, todos devem estar conscientes de sua responsabilidade no papel desempenhado. 
Por outro lado, nota-se a importância das açōes do composto promocional frente aos diferentes públicos e mercados da empresa, que devido ao processo de globalizaçăo, requerem mais eficiência em suas estratégias de comunicação.

\subsection{EDUCAÇÃO AMBIENTAL}

Durante a história da vida humana sobre a Terra, o processo evolutivo levou o homem a inventar técnicas mais sofisticadas e avançadas de manuseio dos recursos naturais nas diversas atividades destinadas à satisfação de suas necessidades básicas.

Com o surgimento das grandes cidades e o crescimento populacional, cresceu a demanda por bens de consumo. Atender a essas demandas pressupunha mudanças na forma de produzir, determinando uma maior intervenção na natureza.

Observou-se nas cidades o surgimento de problemas ambientais, como a poluição das águas e o acúmulo de lixo. 
$\mathrm{Na}$ pesquisa desenvolvida sobre "O que o brasileiro pensa sobre o meio ambiente" pelo MMA; MAST/CNPq (O que o brasileiro..., 1997), foram destacados alguns pontos relevantes, como:

- Há significativa consciência ambiental, embora o brasileiro se considere pouco informado sobre questōes relativas ao meio ambiente;

- O nivel de informação do brasileiro sobre problemas ambientais cresceu pouco, e $95 \%$ alegam nunca ter ouvido falar da Agenda 21;

- $80 \%$ da população brasileira têm grande simpatia pelas organizaçōes que atuam e trabalham na defesa do meio ambiente; e

- $95 \%$ dos brasileiros acreditam que a educação ambiental é a chave para a mudança, sendo favoráveis à obrigatoriedade do tema nas escolas.

A Agenda 21 (1997), convocada pela Assembléia Geral das Naçōes Unidas, foi realizada visando elaborar estratégias que permitissem interromper e reverter os efeitos da degradação ambiental, recomendando o chamado desenvolvimento sustentável, conciliando a preservação da natureza com o crescimento econômico.

A educação ambiental abordada no capitulo 36, item 36.3 da Agenda 21 (1997) enfatiza a importância do ensino formal e informal para modificar as atitudes das pessoas em consonância com o desenvolvimento sustentável, integrando todas as disciplinas e empregando métodos formais e informais, bem como meios efetivos de comunicação. 
Nesse sentido, a Constituição Federal (BRASIL, 1988) e a Constituição Estadual de São Paulo (SÃO PAULO, 1989) prevêem a promoção da educação ambiental, porém, conforme apontado por Santos A S R (1999), pouca coisa é feita para sua implantação concreta no Brasil.

Com a publicação da Lei n. 9795 (BRASIL-D.O.,1999), institui-se a Política Nacional de Educação Ambiental que aponta como um dos princípios básicos "o enfoque humanista, holístico, democrático e participativo (Art. $4^{\circ}$ - Inciso I)".

A Secretaria de Estado do Meio Ambiente possui um Programa Estadual de Educação Ambiental que tem em suas atividades, entre outras atribuições, a produção de material didático para orientar o estabelecimento de estratégias e diretrizes para uma Política Estadual de Ecoturismo. Complementando a iniciativa, foi criado através de Decreto Estadual n.42.798 (SÃO PAULO, 1998) o Programa Núcleos Regionais de Educação Ambiental que objetiva descentralizar ações e proporcionar a participaçāo democrática e regionalizada de órgãos do Governo e da sociedade civil. 


\subsection{ATIVIDADES DE MARKETING SOCIAL-SISTEMA DE INFORMAÇÕES}

O Marketing tem sido definido de maneiras diferentes por diversos autores, porém diferem muito pouco em seu significado e conteúdo que é ligado ao fato da transferência de valores ou troca.

Em uma organização, a venda de um produto ou serviço é a finalização de todo um esforço de marketing que antecede essa ação, com o objetivo de assegurar a satisfação de um consumidor, preparando-o dessa forma para futuras vendas e assim perpetuar a empresa e sua sobrevivência.

Dessa forma, no ambiente de marketing, as informações serem essenciais é uma necessidade permanente para a formulação de políticas e tomadas de decisões, facilitando previsōes, planejamento, desenvolvimento e controle de todo um processo.

As informaçōes são importantes porque reduzem ou minimizam o risco e fatores de incertezas, aumentando as alternativas para tomada de decisões.

Com o processo de globalização, as empresas passaram a ser mais agressivas e a ter prazos de resposta mais curtos diante de seus concorrentes que passaram a oferecer mais beneficios e serviços com 
preços mais reduzidos. Por outro lado, os consumidores tornaram-se mais exigentes e conscientes, evoluindo de necessidades para desejos.

Nesse enfoque, as empresas precisam tratar seus clientes de forma individualizada e conhecê-los melhor.

Vavra (1992) em sua análise observa que no marketing tradicional as empresas investem pesadamente em propaganda e promoçāo, principalmente no lançamento de novos produtos, e esperam poder medir o total de vendas nesse periodo.

Mas os resultados não são satisfatórios, pois não há como medir os resultados e como disponibilizar alguma informação sobre o consumidor que é motivado pela compra e do que não é atingido pela mídia, que na visão de Vavra (1992):

"A empresa que pratica o marketing convencional espera que a propaganda através de mídia de massa gere consciência e interesse, tanto entre varejistas como entre consumidores, que no final são transmitidos em disponibilidade de mercado e vendas. Entretanto, não existe nenhuma maneira de relacionar qualquer venda a uma propaganda especifica ou mesmo à propaganda em geral. A empresa que utiliza o marketing convencional (principalmente para o lançamento de um novo produto) não 
tem uma idéia clara do sucesso ou rentabilidade do produto, porque ela está gastando para gerar consciência e interesse

- ambos, itens inaceitáveis para a demonstração do resultado da empresa."

Assim uma grande parte das empresas tem investido no marketing direto e na criação de banco de dados, o que possibilita um melhor conhecimento de seus clientes, além de permitir mensurar o valor das compras de seus clientes ao longo de um período e analisar seu tamanho ou por quê compra pouco. Permitindo, dessa forma, uma análise mais detalhada de seus clientes.

Por exemplo, uma empresa que tem um grande potencial de compra pode ser analisada por seu volume de pedidos e sua freqüência de compra. Com isso, pode-se detectar falhas em algum elo da empresa, pode ser que algum benefício não esteja sendo oferecido, e que o cliente o valorize. Um bom sistema de informações integrado por toda a empresa permite uma correção do atraso no prazo de entrega, e com um tempo de resposta muito maior do que o da concorrência, além de visualizar novos horizontes.

Cada pedido recusado ou aceito deve ser cuidadosamente analisado, visando aprimorar o sistema e auxiliar na identificaçāo de falhas e pontos fortes da empresa. Vavra (1992) aponta algumas vantagens em uma 
empresa que utiliza banco de dados, sendo "diferente e melhor", conforme segue:

- "Acessibilidade - Habilidade para identificar cada cliente e atingi-lo individualmente.

- Mensuração - saber se cada comprador fez ou não uma compra, exatamente o que comprou, como, onde e quando foi feita a compra (e seu histórico de compra).

- Flexibilidade - oportunidade de atrair diferentes clientes, de diferentes maneiras e em ocasiões diferentes.

- Contabilização - obtenção de quadros precisos da rentabilidade bruta de qualquer evento de marketing e dados qualitativos mostrando os tipos de clientes que participaram de cada evento especifico."

A essa relação, acrescenta-se a contribuição de Shaw, Stone (1993), sendo:

- "É mensurável. Respostas a campanhas são medidas, capacitando-nos a identificar a eficácia de diferentes abordagens.

- E passivel de ser testado. Podemos testar a eficácia de diferentes elementos de nossa abordagem - o produto, a comunicação, a oferta (como o produto é apresentado para atrair o cliente), o mercado-alvo, e assim por diante. Os testes podem ser realizados rapidamente; logo, podemos 
atuar rapidamente nos resultados. Podemos usar resultados de campanha de testes para prever as vendas mais precisamente, ajudando-nos a administrar os estoques mais eficazmente.

- É seletivo. Podemos direcionar campanhas com exatidão, porque nos comunicamos com clientes especificos.

- Podemos personalizar a comunicação com cada cliente, incluindo detalhes relevantes para eles e não para outros. Isto geralmente aumenta a taxa de respostas.

- É flexivel. Podemos programar nossas campanhas para obter seu efeito no momento exato em que queremos."

Os autores lembram que o marketing com banco de dados só se tornou viável em função dos avanços tecnológicos da informação e da compreensão da função estratégica que essa tecnologia passou a assumir.

Shaw, Stone (1993) analisam o trabalho de Porter (1991) que identificou áreas de oportunidades competitivas para a tecnologia de informação, sob uma ótica mais abrangente, utilizando seu difundido gráfico das forças competitivas que relaciona o poder de negociação dos fornecedores e compradores, as ameaças de produtos ou serviços substitutos e novos entrantes com a rivalidade entre as empresas, que refletiram em:

- "Mudança da base de competição. 
- Reforço dos relacionamentos com os clientes.

- Eliminação de problemas de fornecedores.

- Levantamento de barreiras contra concorrentes novatos ou ingressantes.

- Criação de novos produtos."

$\mathrm{Na}$ análise dos autores, as áreas de oportunidade competitiva para a tecnologia de informação, propostas por Porter (1991), deveriam ser avaliadas e julgadas não somente por "... custos, benefícios, formas especificas de armazenagem, processamento e comunicação da informação." Shaw, Stone (1993).

Os autores sinalizam que essa é uma oportunidade para as empresas que podem, utilizar seus bancos de dados como uma estratégia competitiva e estabelecer uma posição de superioridade. Através da construção e exploração de bancos de dados de seus clientes, tornar as empresas mais competitivas por meio de cada um dos tópicos propostos por Porter (1991), constituindo uma estratégia para a empresa.

Mas existe um problema na função de marketing que é simplesmente o fato de que muitos tomadores de decisões não sabem o que realmente desejam em termos de informações, quando precisam delas, quando as obtêm e como utilizá-las. 
Dessa forma, encomendam pesquisas qualitativas e quantitativas que não solucionam o problema; muitas vezes nem sabem qual é.

Um fato deve ser observado de acordo com Denser (1979), dentro da empresa, existem dois tipos de informações: as que existem em algum lugar dentro da empresa sem que as pessoas tomem conhecimento, e as que os gerentes sabem existir.

Dessa forma, o autor classifica as informações pelos tomadores de decisões na área de marketing como as externas que estão ligadas aos fatores e forças incontroláveis da empresa, e as internas relacionadas com os aspectos controláveis da empresa.

Segundo observa Barrizzelli (1995), para garantir uma aderência estratégica, as informaçōes necessárias ao gerenciamento do processo de marketing devem estar relacionadas ao processo de planejamento da empresa. Lembrando que muitos sistemas de informaçōes de marketing são apenas conjuntos de informações, e que existem sistemas isolados que deveriam ser redesenhados para se tornar parte elementar do sistema de gerenciamento do negócio.

É importante observar que em uma empresa existem os três niveis hierárquicos que demandam informações sob enfoques diferentes, sendo o operacional, o tático e o nível estratégico, cujas visōes e necessidades de informaçōes são diferentes, e suas conseqüências, idem. 
$\mathrm{Na}$ abordagem de Lesca; Almeida (1994), a informação é um vetor estratégico muito importante, que pode multiplicar ou anular a sinergia dos esforços no resultado. Os autores afirmam que o desempenho de uma empresa está ligado a três fluxos de informação, sendo:

- Fluxo da informação coletada externamente à empresa e utilizada por ela,

- Fluxo da informação produzida pela empresa e destinada à própria empresa,

- Fluxo da informação produzida pela empresa e destinada ao mercado.

Os autores salientam a importância da informação informal dentro de uma organização, relacionando-a como um "cimento", vital para a empresa, exemplificando esse tipo de informação como jornal interno, reunião de serviço, relatório comercial com impressões sobre um cliente e as próprias açōes publicitárias desenvolvidas pela empresa.

Podemos notar com essa abordagem que as fontes de informação de uma empresa são as mais variadas e de diversas procedencias. Um ponto, os diversos autores têm em comum, que existem duas classificações de informações utilizadas pelos tomadores de decisões na área de marketing, as externas e as internas. Denser (1979) propõe uma classificação que pode ser sintetizada, conforme segue na tabela 2: 
TABELA 2: Classificação de informaçōes

\begin{tabular}{l|ll}
\hline \multicolumn{1}{c|}{ EXTERNAS } & \multicolumn{1}{|c}{ INTERNAS } \\
(Planejadas e incidentais/aleatórias) & (Planejadas e incidentais/aleatórias) \\
\hline - Consumidor - intermediário e final & Produto \\
- Fornecedor & $\begin{array}{l}\text { Preço } \\
\text { - Concorrente }\end{array}$ & $\begin{array}{l}\text { Publicidade e promoção de } \\
\text { vendas }\end{array}$ \\
- Estrutura de distribuição & Venda pessoal \\
- Governo & - Conjuntura econômica & \\
- Outros centros de lucro marketing e custos não & pertencentes à área de marketing \\
- Empresa & \\
\hline Tecnologia existente & \\
\hline
\end{tabular}
Fonte: Adaptado de Denser (1979)

Percebe-se que obter as informações apenas não é suficiente. É necessário sistematizar o processo de coleta, analisando a procedência e a fonte para alimentar o sistema. De acordo com suas necessidades, considerando o processo de transmissão, é um elemento importante na elaboração do projeto documentar os procedimentos e tomar um grande cuidado com os softwares e hardwares utilizados no sistema.

Shaw, Stone (1993) recomendam que é preciso verificar se os equipamentos estão dimensionados de acordo com a demanda gerada pelo sistema, se a capacidade de armazenagem de dados permite uma recuperação rápida e fácil e se os softwares são compativeis com os outros já instalados, facilitando a comunicação e a migração de dados. Recomendam que sejam feitos testes e amostras estatísticas para verificar o desempenho e criar mecanismos de controle para gerenciar o sistema. 
Barrizzelli (1995) lembra que para reunir informações, são desenvolvidas atividades, como pesquisa de marketing para uma busca especifica, recuperação das informações arquivadas e monitoramento de jornais, revistas e relatórios especiais que constituem a inteligência de marketing.

Acrescenta ainda que para o processamento de transformar dados em informações, deve-se:

- Avaliar as informação quanto à confiabilidade e à utilidade;

- Sintetizar as informações em relatórios resumidos;

- Indexar, permitindo que a armazenagem e a recuperação da informação sejam rápidas;

- Disseminar informações para os usuários através de relatórios, terminais de computadores, periódicos, etc,

- Armazenar seletivamente conforme o tempo necessário que cada informação requer para ficar disponível para o usuário.

Percebe-se que os autores têm uma preocupação com o sistema de inteligência de marketing, principalmente com sua concorrência. Porter (1991) enfatiza o foco da função de um sistema de inteligência sobre o concorrente, recomendando atenção nos passos de coleta, compilação e catalogação dos dados de campo e os publicados, bem como a análise e a comunicação ao estrategista. 
Para a construção de um banco de dados de clientes, Vavra (1993) propõe quatro etapas, conforme seguem:

1. "Antecipar as principais necessidades de informações;

2. Planejar cuidadosamente os componentes de um banco de dados, mas mantê-lo aberto para permitir mudanças futuras.

3. Não atrasar a elaboração de um banco de dados, tentando definir sua estrutura final: elaborar e utilizar um banco de dados menor, menos grandioso de início, em vez de querer avaliar seu valor para o negócio antecipadamente. Ou seja, começar o quanto antes possivel.

4. Envolver o maior número possivel de departamentos e individuos."

O autor ressalta ainda que a elaboração de um banco de dados pode tomar duas dimensões, e como deve ser elaborado interna e externamente, lembrando ainda que deve haver um responsável pelo banco de dados e pela alimentação das informações recebidas, o que será incluído, e como deve ser o tratamento das informaçōes.

Por outro lado, Kotler (1998) comenta que na longa história das empresas, a atenção da administração esteve voltada para a administração de dinheiro, máquinas, pessoas, materiais, ressaltando a importância dos sistemas de informações, e define: "Um sistema de 
informações de marketing consiste de pessoas, equipamentos e procedimentos para reunir, classificar, analisar, avaliar e distribuir as informações necessárias, oportunas e precisas para os tomadores de decisð̃es de marketing."

$\mathrm{Na}$ abordagem do autor, ele comenta que o sistema de informações tem o papel de avaliar as necessidades de informações para desenvolver as mais úteis e distribuí-las de forma adequada no momento certo. Lembrando que estamos na era da informação, e que o sistema de informações é um recurso que deve ser muito bem cuidado por parte das empresas, para poder subsidiar e auxiliar nas tomadas de decisões.

Kotler (1998) recomenda que seja criado um comitê interno de sistema de informações de marketing, relacionando o que os administradores pensam que necessitam com o que realmente necessitam e que seja economicamente viável.

Em seu modelo, Kotler (1998) propõe que o sistema seja desenvolvido através de registros internos da empresa e que as atividades de inteligência de marketing e a pesquisa de apoio às decisões sejam ágeis e rápidas para poder antecipar açōes, conforme segue na figura 5. 
SISTEMA DE INFORMAÇOES DE MARKETING

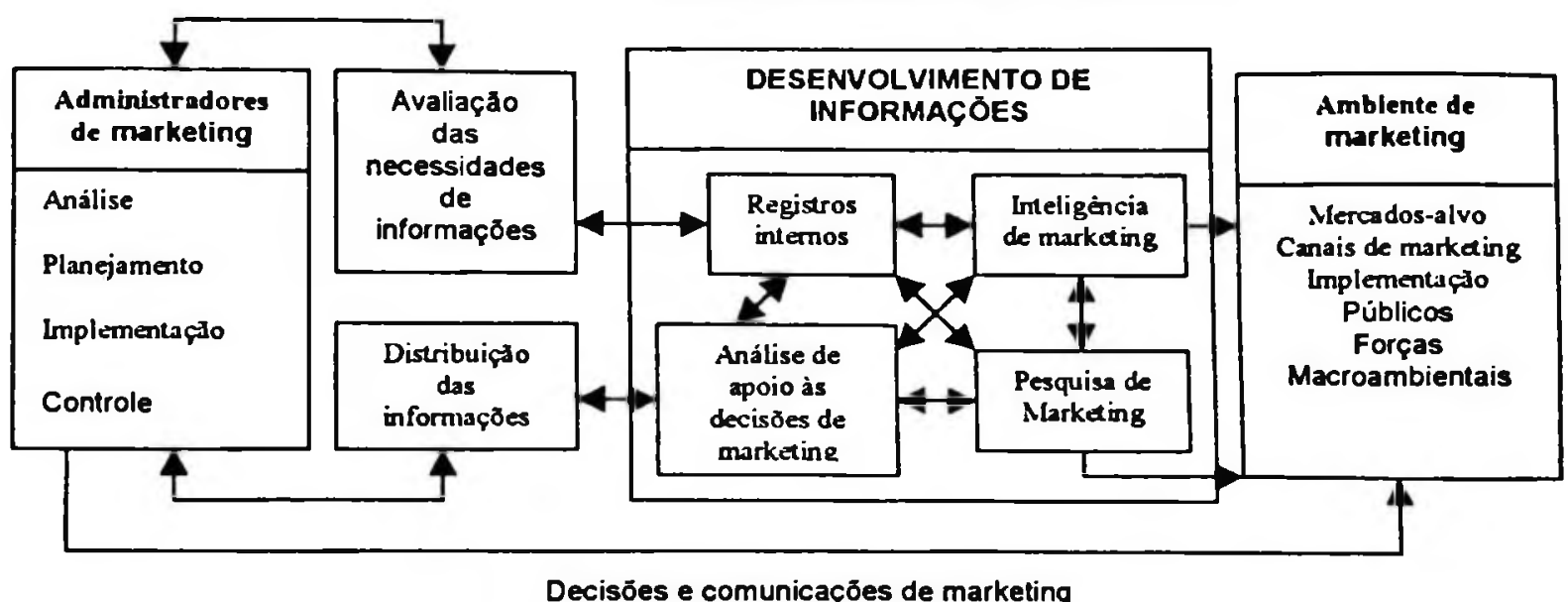

FIGURA 5: Sistema de informaçōes de marketing

Fonte: $\quad$ Adaptado de Kotler (1998, p.112)

O modelo apresentado pelo autor é complexo e fundamentado nos registros internos, demonstrando muito mais um gerenciamento contábil e análise de relatórios de vendas, do que um sistema de informações propriamente dito. As informações externas são pesquisadas nos canais de distribuição e com pesquisas efetuadas junto aos clientes.

As análises internas propostas por Kotler são úteis, mas talvez seja insuficiente para constituir e subsidiar todo um processo de decisāo de marketing, ficando, de certa forma, muito limitadas e restritas, pois conforme o próprio autor cita em seu modelo, estamos na era da informação. O consumidor, bem como os concorrentes, está cada vez mais informado sobre tudo, tendo acesso a qualquer tipo de informação.

Observa-se que na proposta do autor, ele não contempla os cenários alternativos, bem como tendências e mudanças de padrões que 
vêm ocorrendo na sociedade, e que as forças do macroambiente exercem grande influência sobre o conjunto, tornando o modelo inviável de ser aplicado, embora didaticamente seja ilustrativo, não parte das necessidades do cliente interno.

McCarthy; Perreault (1997) enfatizam que as decisões tomadas pelos gerentes de marketing, geralmente, sāo baseadas em julgamento próprio e com poucos dados confiáveis e que, em mercados dinâmicos, a simples análise de rotina dos dados, apesar de ser valiosa, deve utilizar pesquisas para suplementar os dados já disponiveis, apresentando um sistema de informações, conforme segue na figura 6. 


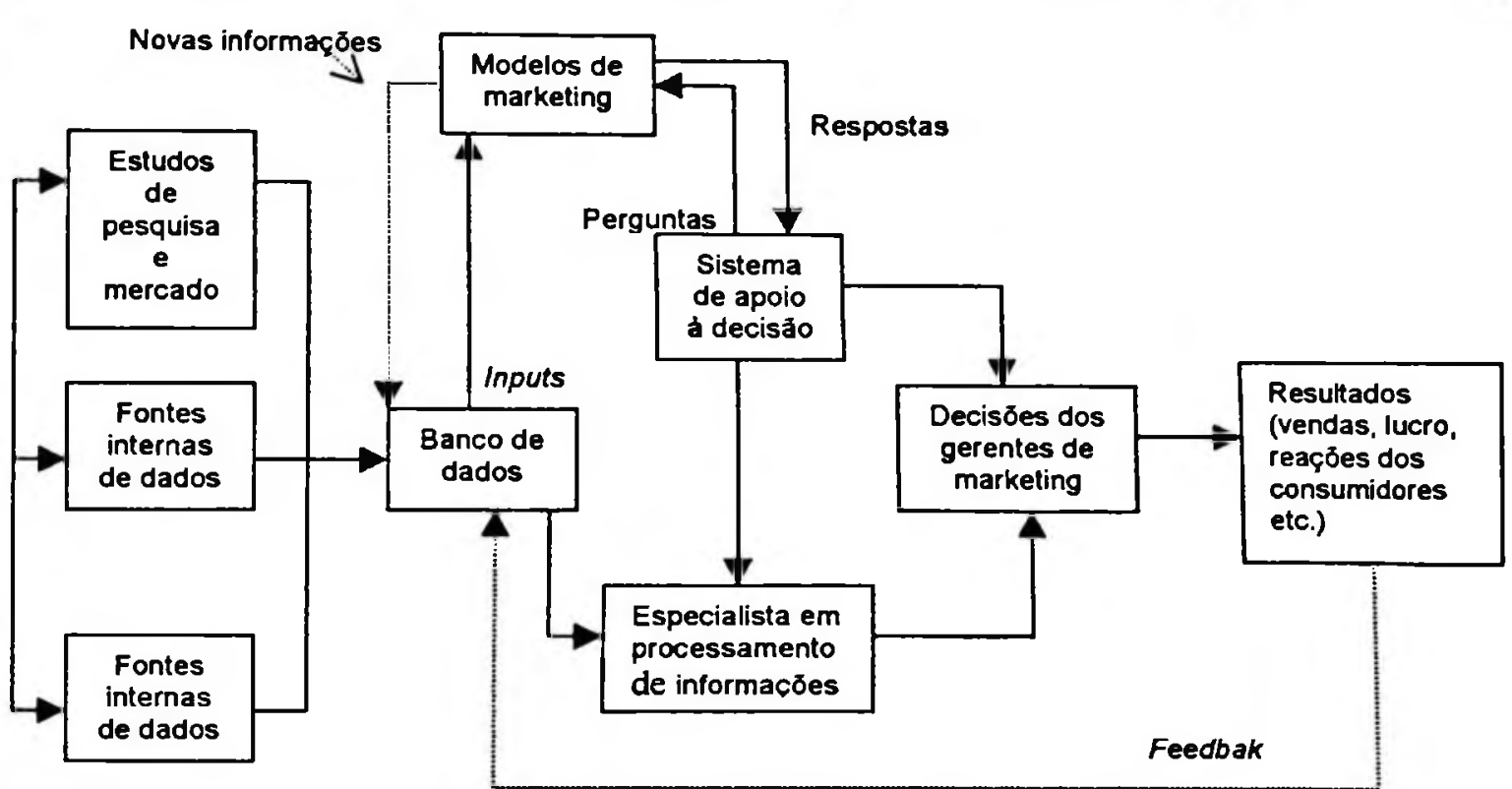

FIGURA 6: Elementos de um sistema de informações de marketing completo

Fonte: $\quad$ Adaptado de McCarthy: Perreault (1997, p.100).

No modelo apresentado por McCarthy; Perreault (1997), os autores fazem um comentário sobre a importância do sistema de informaçōes, que sua utilizaçāo torna os gerentes mais ávidos por informações, e que muitas empresas não utilizam o sistema de informações por não possuírem um. Com os avanços da informática, os gerentes poderão acessar instantaneamente as informaçōes, e os autores alertam que um gerente de vendas pode obter uma informação que acessou e que não necessitava.

McCarthy; Perreault (1997), contemplam um feedback entre os bancos de dados e os resultados das vendas/lucros e reação dos consumidores, porém enfatizam que uma pesquisa de marketing se faz 
necessário e que as informações externas podem ser obtidas por estudos de pesquisas de mercado, fontes internas de dados e fontes externas, utilizando um especialista em processamento de informações.

Os autores visualizam os sistemas informatizados, e com o advento da informática, nem sempre o que há disponivel é o que os gerentes necessitam, portanto, criando uma diferença entre dado e informação.

\subsection{O PROCESSO DE COMUNICAÇÃO}

Na visão de Cobra (1997), o processo de comunicação “...é persuasivo, à medida que atinge o público-alvo", e as empresas alocam recursos em seu orçamento na expectativa de persuadir seus consumidores atuais e potenciais a adquirir seus produtos e serviços.

Nota-se na literatura que os autores comentam sobre a importância de uma mensagem ser ouvida ou não, e para isso, é necessário entender o processo de comunicação, que basicamente é o mesmo apresentado por eles, porém com pequenas modificaçōes. O processo de comunicação, de forma simplificada, pode ser representado conforme segue na figura 7 . 


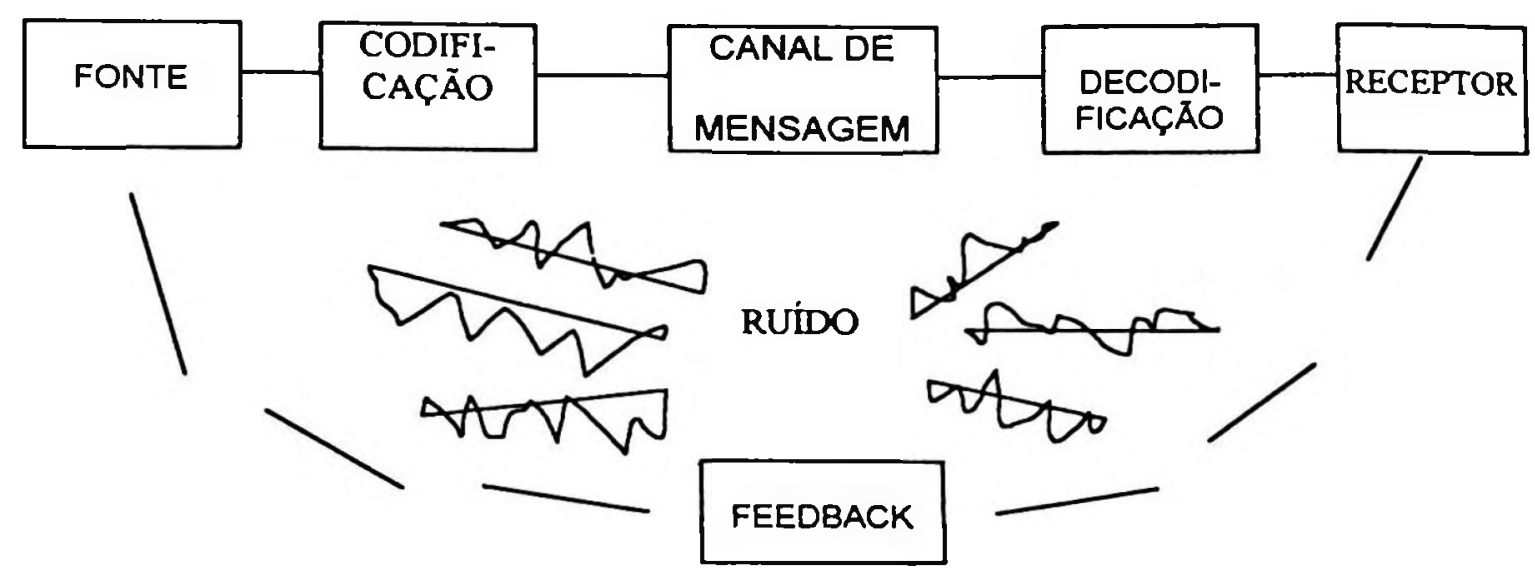

FIGURA 7: O processo de comunicação

Fonte: $\quad$ Adaptado de McCarthy; Perreault (1997, p. 233)

No esquema, nota-se parte de uma fonte onde o emissor de uma mensagem tenta transmitir a um receptor, ou seja, um consumidor potencial é retroalimentado por informações que podem vir de um vendedor. O ruído é qualquer distração que possa reduzir a eficácia do processo de comunicação, como conversas durante um anúncio de televisão. Os profissionais de propaganda planejam mensagens que devem reconhecer que muitas distrações são possiveis ou, seja, ruidos podem interferir nas comunicações.

$\mathrm{Na}$ abordagem de Calazans (1992), ele alerta para a propaganda subliminar multimidia, na qual somos bombardeados por mensagens e informações, sem percebermos que fazem parte do nosso cotidiano, como vitrines de lojas, bancas de jornais, outdoors, grafites e tantos outros meios. 
Dessa forma, Kotler (1998) ressalta e delineia os fatores que moderam o efeito de uma comunicação, como:

1. "Quanto maior o monopólio da fonte de comunicação sobre o receptor, maior será a mudança ou efeito sobre o receptor em favor da fonte.

2. Os efeitos da comunicação são maiores quando a mensagem coincide com as opiniōes, crenças $e$ disposição do receptor.

3. A comunicação pode produzir mudanças mais eficazes sobre assuntos não familiares, pouco sensiveis e periféricos, que não estejam situados no centro do sistema de valores do receptor.

4. É mais provável que a comunicação seja eficaz quando se acredita que a fonte possui experiência, alto status, objetividade ou simpatia, mas principalmente quando a fonte tem poder e pode identificar-se com ela.

5. O contexto social, grupo ou grupo de referência mediará a comunicação e exercerá influência, quer ela seja ou não aceita."

As etapas para o desenvolvimento de um programa de comunicação e promoção global devem ser abordadas pelos especialistas em marketing, ou seja, identificar a audiência-alvo, determinar os objetivos da comunicação, preparar a mensagem, selecionar os canais de 
comunicação, decidir sobre o composto de comunicação, mensurar resultados da promoção e administrar e coordenar o processo global de comunicação de marketing, sem esquecer o ciclo de vida do produto, pois os consumidores agem e reagem diferente em cada estágio do ciclo.

\subsection{A COMUNICAÇÃO NO COMPOSTO PROMOCIONAL}

Segundo Schewe; Smith (1982), a palavra comunicação baseia-se no latim "commom", em que o objetivo da comunicação é o de partilhar alguma coisa em comum, e para que isso aconteça, o significado a ser transmitido tem de ser propriamente codificado e decodificado, isto é, envolve uma fonte e um receptor.

Na visão de Santos J R (1992), comunicação "é o mecanismo através do qual existem e se desenvolvem as relações humanas". Em sua abordagem faz uma retrospectiva na busca do significado do que é a palavra comunicação e penetra nas raizes da história dos homens, e verifica que "...tudo o que é vida é comunicação, porque implica necessariamente no transporte de idéias e objetos de um ponto para o outro. O sangue transporta oxigênio para as células e, ao fazê-lo, está a comunicar." 
Em sua obra, o autor relata como foi construído o conceito de comunicação e cita uma história de 1935, quando um filósofo americano ao tentar escrever um livro que se chamava "Tratado sobre comunicaçāo", foi proibido, pois os editores pensavam que se tratava de uma obra sobre linhas de telefone.

Assim, Santos J R (1992) observa que a palavra comunicação, embora esteja ainda associada ao transporte de objetos físicos, é entendida em geral como sendo "..o transporte de idéias e emoções expressas através de um código. Ou seja, comunicar significa essencialmente transmitir sentidos, casuais ou intencionais, de um ponto para o outro."

Conforme observa Schewe; Smith (1982), seriam feitas poucas trocas sem a comunicação, e nāo adianta ter um produto em disponibilidade se não for comunicado ao mercado. A comunicação provê informações, diz ao mercado e a seus consumidores que existe um produto que satisfaz suas necessidades e desejos.

Os autores evidenciam que comunicação é informar e persuadir, naturalmente em um fluxo de duas mãos de direção, e que algumas categorias de produtos solicitam muito pouca persuasão por parte dos especialistas em marketing. 
Mas como os especialistas em marketing se comunicam com o seu mercado? Em geral, é através das atividades promocionais de propaganda, venda pessoal e promoção de vendas. Embora estas sejam as principais ferramentas da comunicação utilizadas para encorajar a troca, não são os únicos meios para se comunicar.

O composto de marketing inteiro atua no processo de comunicação. Ou seja, tudo o que é feito, como cada atividade percebida pelo mercado, comunica alguma coisa sobre o que é oferecido. Como o produto, que comunica sua utilidade pela forma, função, finalidade e pela satisfaçāo simbólica que transmite.

A marca nominal de um produto assegura ao consumidor qualidade constante, e o produto atua conforme o esperado. A embalagem de um produto também comunica, identificando o produto, a marca e suas caracteristicas.

Ainda segundo Schewe; Smith (1982), as garantias também são outra forma de se comunicar, pois garantem satisfação ao consumidor que espera que o produto funcione conforme foi divulgado.

O preço também comunica, pois diz aos consumidores o que os especialistas em marketing acreditam que o produto vale em uma troca, ou seja, se um produto custa mais caro, comunica alta qualidade, mesmo que em alguns casos não exista status, sensação de exclusividade; ao 
passo que um preço mais baixo pode passar a impressão de qualidade inferior. As variações de preços e descontos também transmitem significados, dando a impressão de danos, validade vencida e liquidação.

Por fim, o próprio sistema de distribuição, no qual a escolha do canal e a movimentação do produto também se comunicam. Dependendo do ponto em que o produto é ofertado, pode-se comunicar a qualidade e o valor do produto, que o consumidor percebe como sendo de alta ou baixa qualidade.

McCarthy; Perreault (1997) comentam que o objetivo de informar é muito importante. Durante o estágio inicial do ciclo de vida de um produto, quando o conceito é realmente novo, a promoção tem a função de informar e educar os consumidores para construir uma idéia geral do produto e não apenas a marca da própria empresa.

Ainda segundo os autores, para a promoção de uma empresa ser eficaz, seus objetivos de promoção devem estar claramente definidos, porque o composto promocional para ser realizado corretamente depende do que a empresa deseja realizar.

Observam que na promoção, deve-se considerar três objetivos básicos, que são informar, persuadir e lembrar os consumidoresalvo sobre o composto de marketing e a empresa. Ressaltando que a empresa tem como um objetivo de persuasāo tentar desenvolver um 
conjunto favorável de atitudes para que os consumidores adquiram seu produto.

Tanto McCarthy; Perreault (1997) como Kotler (1998) comentam que a propaganda é uma das ferramentas mais comuns utilizadas pelas empresas para dirigir comunicação persuasiva ao seu público-alvo, e concordam quanto à importância da definição e clareza de objetivos.

Kotler (1998) indica vários métodos de promoção que estāo disponiveis e define a propaganda como "...qualquer forma paga de apresentação impessoal e de promoção de ldéias ou seniços por um patrocinador identificado."

O autor apresenta três tipos de propaganda, a informativa, que é utilizada intensamente no estágio pioneiro de uma categoria de produtos; a persuasiva, que é muito importante em um estágio competitivo, sendo o objetivo da empresa seletivo para promover um marca especifica e, por fim, a propaganda de lembrança, que é muito importante no estágio de maturidade do produto, servindo de reforço procurando assegurar os consumidores conquistados.

Cobra (1997) observa que o sucesso da mensagem de propaganda repousa mais na definição clara dos objetivos de marketing do que nos objetivos exclusivamente da comunicação. 
É importante lembrar que a publicidade conceituada por McCarthy; Perreault (1997) é "...qualquer forma gratuita de apresentação impessoal de idéias, bens ou serviços.•

Os autores abordam a comunicação como sendo a informação entre vendedor e comprador potencial ou outros integrantes do canal para influenciar atitude e comportamento. Os especialistas de marketing comunicam as mensagens dependendo da composiçăo dos vários métodos promocionais escolhidos. De acordo com o que se quer comunicar sobre determinada necessidade e atitudes dos consumidores.

Assim, a venda pessoal envolve um feedback e uma comunicação oral direta entre os vendedores e os consumidores potenciais. A venda de massa é outra atividade que envolve comunicação com grande número de consumidores, $\dot{E}$ interessante observar que na literatura os diversos autores, de formas diferentes, abordam os mesmos temas.

Além disso, pode-se também citar a promoção de vendas, que tem grande importância em incentivos de curto prazo, e as atividades de relaçōes públicas para promover ou proteger a imagem de uma empresa. 


\section{CAPÍTULO 3 - PLANEJAMENTO DA PESQUISA}

Conforme apresentado no capítulo anterior, partindo dos conceitos e atividades formulados de marketing, analisou-se o conceito de marketing social e comunicação persuasiva.

Optou-se pelo delineamento do estudo de caso visando confrontar os conceitos discutidos na esfera teórica com a realidade empirica das organizaçōes, analisando a realidade com a teoria. Por se tratar de um tema pouco explorado na literatura, essa interação pode gerar novos insights para a área da administração.

\subsection{METODOLOGIA DA PESQUISA}

De acordo com Mattar (1994), há diferentes classificaçōes dos tipos de pesquisas adotadas por diversos autores da área. Consistindo em três métodos de pesquisa que o próprio autor classifica em exploratórias e conclusivas, podendo ser esta última descritiva ou causal, conforme segue figura 8. 


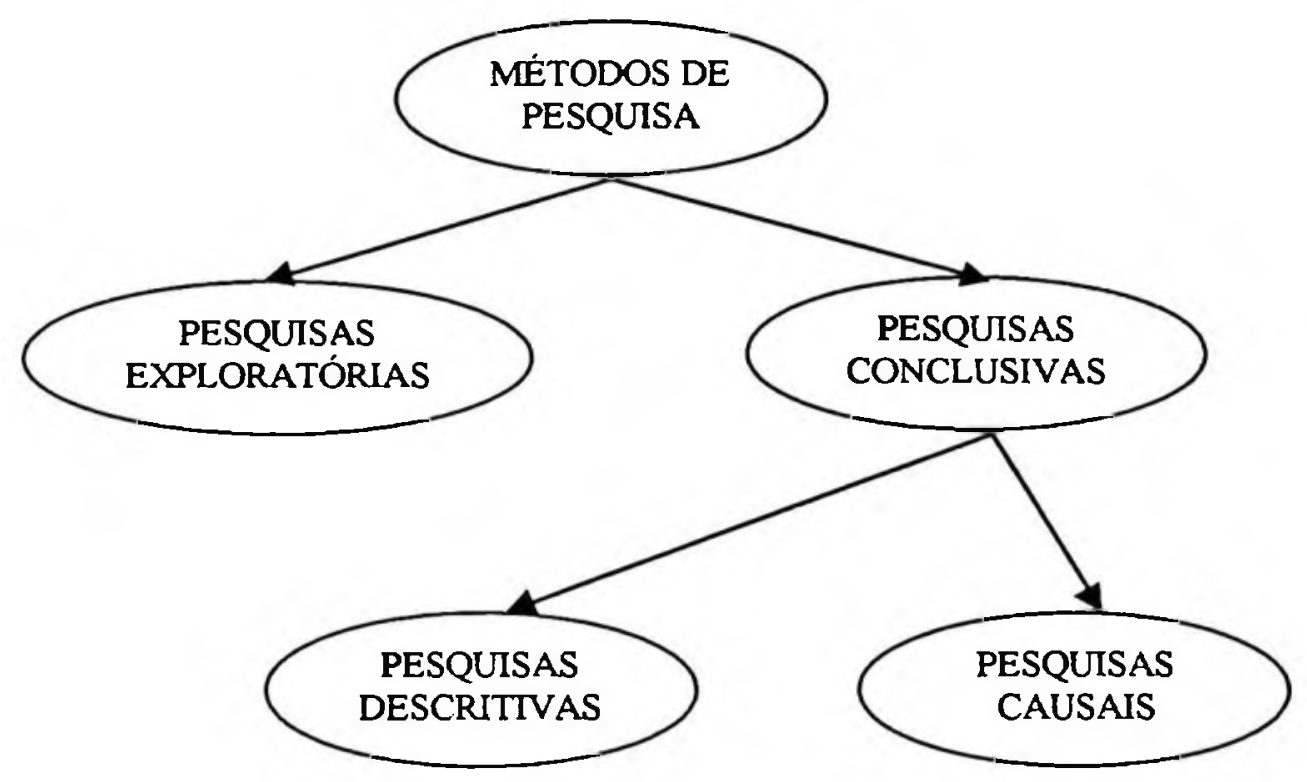

FIGURA 8: Métodos de Pesquisa

Fonte: $\quad$ Adaptada de Mattar (1994, p.79)

Mattar (1994), por simplificação didática, considera a classificação das pesquisas em exploratórias, descritivas e causais, sendo que a pesquisa exploratória permite descobertas para novas idéias; já a descritiva determina a freqüência com que algo ocorre ou o relacionamento entre duas variáveis, e a pesquisa causal procura determinar as relaçōes de causa-efeito de fenômenos determinados.

Ainda segundo Mattar (1994), "a pesquisa exploratória visa prover o pesquisador de um maior conhecimento sobre o tema ou problema de pesquisa em perspectiva. Por isso, é apropriado para os primeiros estágios da investigação, quando a familiaridade, o conhecimento e a compreensão do fenómeno do pesquisador são, geralmente, insuficientes ou inexistentes." Esse tipo de trabalho também é utilizado para iniciar um processo contínuo de pesquisa, e utiliza normalmente, como estratégias de pesquisa, o estudo de caso e a pesquisa bibliográfica. 
Na visão de Selltiz et al. (1975), cada pesquisa varia de acordo com o objetivo da pesquisa, e a principal característica é referente à descoberta de intuições e idéias em estudos exploratórios, e portanto..."o planejamento da pesquisa precisa ser suficientemente flexível, de modo a permitir a consideração de muitos aspectos diferentes de um fenómeno".

Observando que para Gil (1991) “embora o planejamento da pesquisa exploratória seja bastante flexível, na maioria dos casos assume a forma de pesquisa bibliográfica ou de estudo de caso".

Na maioria das vezes, a pesquisa exploratória é constituida dos seguintes passos: pesquisa bibliográfica, entrevistas com indivíduos que tiveram experiências empíricas com a realidade, que interessa ao pesquisador, observando que grande parte dos conhecimentos e experiências adquiridos não está escrita, e por fim, análise dos dados que possibilite esclarecer a situação da pesquisa.

É importante lembrar que a escolha do método é de suma importância, porém é um instrumento de auxílio e de validação científica do trabalho do pesquisador, deixando a criatividade do mesmo para analisar cada situação.

Convém observar ainda que esses métodos constituem um processo contínuo, em que o pesquisador não conhece ainda o problema e vale-se de uma pesquisa exploratória para ter um conhecimento maior e 
formular hipóteses sobre o comportamento do fenômeno, e em outra fase, testa as hipóteses utilizando-se de uma amostra probabilistica que permita a inferência sobre as relações entre as variáveis em estudo com a população.

Nessa fase, o estudo descritivo busca uma validação dos dados coletados, através da estatística, para que seja possivel comparar a extrapolação de resultados da amostra para a população analisada. E por fim, como uma última fase, busca-se o estabelecimento de relaçōes de causa-efeito entre as variáveis em estudo, que possibilitem a previsibilidade de seu comportamento, como as pesquisas causais.

Considerando que na visão de Mattar (1994), "as pesquisas conclusivas são caracterizadas por possuirem objetivos bem definidos, procedimentos formais, serem bem estruturadas e dirigidas para a solução de problemas ou avaliação de alternativas de cursos de ação." O autor ainda diz que as pesquisas conclusivas podem ser descritivas e causais.

Sob a denominaçāo de pesquisa descritiva, é agrupada uma série de pesquisas cujos processos apresentam características importantes em comum e uma necessidade de conhecer exatamente o que 0 pesquisador quer saber ou pretende com a pesquisa e $\circ$ profundo conhecimento do problema a ser estudado e a necessidade rigorosa do planejamento da pesquisa. 
Complementando, para Selltiz et al. (1975), o planejamento é necessário visando reduzir o viés e ampliar a precisão da prova obtida, que sendo precisa, pode-se afirmar com confiança que se obtenham resultados semelhantes ao repetir a coleta das provas, por isso considera como fundamental a exatidāo. Assim, a pesquisa descritiva é muito utilizada para verificar ou descobrir se existe relação entre variáveis, não sendo do tipo causa-efeito, mas simplesmente relações, descrever características de grupos, e estimar proporçōes de elementos em uma determinada população que tenha comportamentos e caracteristicas especificas.

Quanto às pesquisas causais ou experimentais, a autora considera que os estudos que verificam hipóteses causais exigem processos que não apenas reduzem o viés e aumentam a precisão, mas que também permitem inferências a respeito da causalidade.

Ou seja, visa estabelecer evidências sobre relacionamentos entre variáveis que sugerem relaçōes de causa e efeito. Através da utilização de um experimento, é comum para medir o efeito ou efeitos ocorridos sobre uma ou mais variáveis dependentes, a manipulação consciente de uma ou mais variáveis independentes.

Basicamente a diferença que existe entre as pesquisas descritiva e causal consiste em seus objetivos. A pesquisa descritiva visa responder aos seguintes questionamentos: o quê, quanto, quando e onde, enquanto que a pesquisa causal tem como centro da questão a ser 
respondida o porquê. De acordo com Mattar (1994), "..a pesquisa descritiva tem o objetivo de expor o fenômeno em estudo, enquanto a pesquisa causal procura verificar relações entre variáveis que expliquem o fenômeno em estudo." E geralmente, "..uma pesquisa apresenta uma parte inicial exploratória que ajudará no delineamento da parte conclusiva."

Porém, Mattar(1994) recomenda que ao classificar as pesquisas quanto ao "... objetivo e grau em que o problema de pesquisa está cristalizado - A diferença básica entre a pesquisa exploratória e a conclusiva está no grau de estruturação da pesquisa e em seu objetivo imediato" .

Concordando e comentando, Selltiz et al. (1975) têm a opinião de que cada estudo tem seu objetivo específico, entendendo que este pode ser classificado em quatro amplos agrupamentos:

“1) familiarizar-se com o fenômeno ou conseguir nova compreensão deste, freqüentemente para poder formular um problema mais preciso de pesquisa ou criar novas hipóteses; 2) apresentar precisamente as características de uma situação, um grupo ou um individuo especifico (com ou sem hipóteses especificas iniciais a respeito da natureza de tais características);

3) verificar a freqüência com que algo ocorre ou com que está ligado a alguma outra coisa (geralmente, mas não sempre, com uma hipótese inicial especifica);

4) verificar uma hipótese de relação causal entre variáveis." 
$\mathrm{Na}$ prática, a distinção entre método de pesquisa nem sempre é muito clara, Selltiz et al. (1975) afirmam que "na prática, esses diferentes tipos de estudo nem sempre são nitidamente separáveis. Qualquer pesquisa considerada pode conter elementos de duas ou mais funções descritas como características de diferentes estudos." e "...embora não sejam bem definidas as distinções entre diferentes tipos de estudo, de modo geral é possivel fazer tais distinções; é útil fazê-las, para discutir os planejamentos adequados de pesquisa."

Embora existam elementos de uma ou duas funções comuns em qualquer pesquisa considerada, geralmente existe uma acentuação de apenas uma das funções que levam a pensar que a classificação do estudo na categoria correspondente é a sua principal função.

Convém observar que no processo há uma seqüência lógica entre os métodos de estudo, onde primeiramente é realizada uma pesquisa exploratória para conhecer a realidade, e na seqüência testa-se as hipóteses levantadas, e por fim, busca-se estabelecer uma relação de causalidade entre variáveis, ressaltando que essa seqüência lógica pode ser quebrada, dependendo do problema e a da criatividade do pesquisador, que são determinantes na escolha do método.

Nesta dissertação, o objetivo do trabalho é analisar conceitos e teorias das atividades de comunicação persuasiva de marketing social, baseados em possibilidades reais de verificação em uma situação 
empirica, no caso da "Operação Rodízio da SMANCETESB", que relaciona a questão ambiental na administração pública, visando a melhoria da qualidade do ar, envolvendo a mudança de comportamento e conscientização da população, ressaltando que não há outro caso registrado dessa experiência no Brasil.

Assim, pode-se afirmar que este trabalho enquadra-se na abordagem exploratória, entendendo que o próprio encaixa-se no primeiro objetivo destacado por Selltiz et al. (1975), ou seja, o de familiarizar-se com o fenômeno.

A autora ainda em seus comentários sobre objetivos do estudo exploratório, além da formulação de problemas para investigação mais exata ou para criação de hipóteses, cita várias indicações para a classificação adotada neste trabalho, como:

- Aumentar o conhecimento do pesquisador acerca do fenômeno que deseja investigar em estudo posterior ou de uma situação em que se pretende realizar tal estudo de forma mais estruturada;

- Estabelecimento de prioridades para futuras pesquisas;

- Esclarecimento de conceitos;

- A obtenção de informação sobre possibilidades práticas de realização de pesquisas em situações de vida real. 
Portanto, nesta dissertação, acredita-se que estes objetivos estão contidos no trabalho contribuindo para o aumento de informaçōes sobre o tema proposto, o esclarecimento de conceitos quanto à filosofia do marketing social e comunicação persuasiva e sua aplicabilidade em uma situação empírica, bem como a realização de pesquisas em situações reais, investigando um fenômeno dentro de um contexto real, especificamente da Operação Rodízio, na qual visa-se a mudança de comportamento, e portanto, necessitando de análises mais profundas e intensivas, o que confirma o método de trabalho da pesquisa como sendo a abordagem exploratória.

\subsection{A ESCOLHA DO ESTUdO DE CASO COMO ESTRATÉGIA DE PESQUISA}

Apesar de se pretender conduzir uma pesquisa exploratória, é necessário identificar qual será a estratégia de pesquisa mais adequada a ser utilizada, considerando os objetivos da pesquisa. Campomar (1991) ressalta a importància do método científico como forma para legitimar um conhecimento adquirido empiricamente. Por esse método, qualquer outro pesquisador que repita a investigação nas mesmas circunstâncias e tome os mesmos cuidados obterá o mesmo resultado. Lembrando ainda que " .... 
método cientifico de pesquisa é um conjunto de passos especificos e claramente determinados para obtenção de um conhecimento."

Ainda segundo Campomar(1991), "Quando se fala em estudo de casos, vem logo à mente a idéia do uso de casos como tentativa de reprodução da realidade para o ensino, o que é chamado método do caso."

Em sua análise, Campomar(1991) aborda o "estudo de casos como método de pesquisa social empírica", acrescentando ".... que é completamente diferente. É preciso lembrar, ainda, a existência na literatura da pesquisa no método do caso: pesquisa sobre os resultados de uso do método do caso no processo de ensino. Esta diversidade no uso de palavras iguais para apresentar atividades diferentes tem confundido muitos estudiosos, tanto quando se usa a literatura brasileira, como quando utiliza a literatura estrangeira, traduzida ou não.".

O autor comenta ainda que há muito preconceito quanto à utilização do uso de estudo de casos em pesquisas e aponta duas razões, sendo que a primeira é considerada um método pouco estruturado, fácil e pouco acadêmico, e a segunda, por um grupo que acredita que só o que é quantificável é verdadeiro. 
Campomar (1991) lembra que tanto os métodos quantitativos quanto os qualitativos possuem limitações e que as mesmas devem ser claramente mencionadas.

Bonoma (1985) defende que na escolha do método, idealmente, todos os pesquisadores e as pesquisas buscam altos niveis de integridade dos dados e de seu uso, considerando elos causais da interferência de variáveis externas ao fenômeno e a aceitaçāo ou prevalência dos resultados, estas duas dimensões são consideradas desejáveis e essenciais, portanto, "Uma restrição de ordem prática na execução força o pesquisador a trocar algum elo causal (integridade dos dados) por um grau moderado de prevalência dos resultados devido à própria escolha do problema de pesquisa e do método."

Na visão de Bonoma (1985), há vários métodos de pesquisa empírica relacionados com a solução de compromisso considerada inevitável, conforme segue na figura 9. 


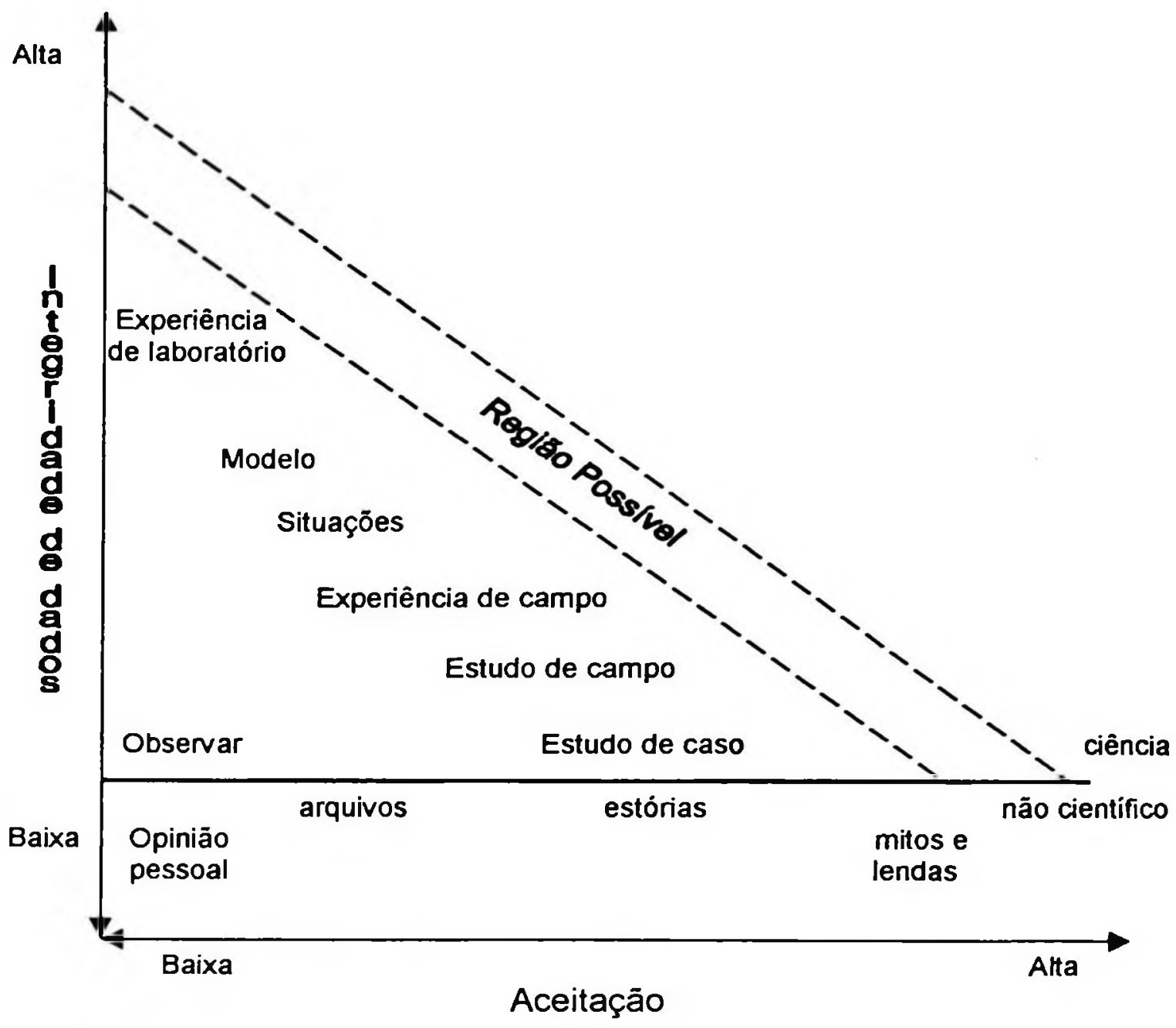

FIGURA 9: Métodos de pesquisa empírica Fonte: $\quad$ Bonoma (1985, p.200)

Quanto às características do problema sob investigação, o autor recomenda que para a escolha do método de pesquisa devem ser considerado, para estabelecer uma relação de compromisso, o propósito da pesquisa e o fenômeno de interesse, vistos por dois ângulos, sendo:

- "O propósito da pesquisa

Uma lista de pontos ao longo do continuum de pesquisa comumente aceita é: descrição, classificação, comparação, 
medição/estimativa, estabelecimento de associações $e$ determinação de causa-efeito. .....Desta forma, estudos voltados para a extrema 'descrição' do continnum podem ser associados mais freqüentemente com a construção teórica, enquanto aqueles próximos ao extremo 'causa-efeito' são usualmente mais usados para validar/invalidar uma teoria." Bonoma (1985)

- O fenômeno de interesse

Primeiro, se o fenômeno pode ser estudado fora de seu contexto natural. Segundo, se ele é passivel de quantificação." Bonoma (1985)

Bonoma (1985) defende a aplicação de métodos e técnicas qualitativas na pesquisa de fenômenos de marketing, dando pouca ênfase na integridade dos dados, pois muitos dos fenômenos de marketing apresentam poucas condições de construção teórica e uma alta complexidade de observação.

Yin (1989) critica que a forma tradicional de avaliação metodológica quanto ao tipo de técnica utilizada, seja ela qualitativa ou quantitativa, para se obter evidências não é fator de diferenciação entre os vários métodos de pesquisa científica, e complementa dizendo que "fomos ensinados a acreditar que estudos de caso eram apropriados para a fase exploratória da investigação, que Surveys e histórias apropriadas para a fase 
descritiva e que experimentos eram a única forma de investigação exploratória ou causal. Esta visão hierárquica é incorreta."

Segundo Yin (1989), quando existe a compreensão de fenômenos sociais complexos, o estudo de caso traz uma importante contribuição ao desenvolvimento do conhecimento nas ciências sociais, observando, dessa forma, que é possivel efetuar uma investigaçāo em que são preservadas as características holísticas e significativas de uma situação real.

O autor define "O estudo de casos é uma forma de se fazer pesquisa social empírica ao investigar-se um fenômeno atual dentro do seu contexto de vida real, onde as fronteiras entre o fenômeno e o contexto não são claramente definidas e na situação em que múltiplas fontes de evidências são usadas" Yin (1989).

A vantagem prática da aplicação do estudo de caso, segundo Gil (1987), se dá na realizaçāo por um único investigador ou por um grupo pequeno, ao contrário de outras técnicas de levantamento que necessitam de grandes volumes de dados coletados, o que propicia uma relativa economia e simplicidade.

Como principal limitação a esse tipo de estratégia de pesquisa, o autor aponta a impossibilidade de generalizaçāo dos resultados obtidos no estudo do fenômeno. 
Segundo Yin (1989), o autor parte da tese de que deve-se utilizar o método ou estratégia de pesquisa a partir da especificação de três condições, definidas pelos seguintes critérios:

1) a forma das questōes de pesquisa proposta;

2) o grau de controle que o pesquisador tem sobre eventos comportamentais;

3) o foco em eventos contemporâneos ou históricos.

Em sua visão, o autor aponta cinco estratégias de pesquisa, bem como situações relevantes para sua escolha, conforme segue na tabela 3. 
TABELA 3: Situações relevantes para estratégias de pesquisa

\begin{tabular}{llcc}
\hline \multicolumn{1}{c}{$\begin{array}{c}\text { ESTRATEGIA DE } \\
\text { PESQUISA }\end{array}$} & $\begin{array}{c}\text { FORMA DO } \\
\text { PROBLEMA DE } \\
\text { INVESTIGAÇÃO }\end{array}$ & $\begin{array}{c}\text { REQUER CONTROLE } \\
\text { SOBRE EVENTOS } \\
\text { COMPORTAMENTAIS? }\end{array}$ & $\begin{array}{c}\text { FOCO EM EVENTOS } \\
\text { CONTEMPORANEOS }\end{array}$ \\
\hline Experimento & Como, Por quê? & Sim & Sim \\
$\begin{array}{l}\text { Levantamento } \\
\text { (Survey) }\end{array}$ & $\begin{array}{l}\text { Quem, O que, } \\
\text { Onde, Quanto? }\end{array}$ & Não & Sim \\
$\begin{array}{ll}\text { Análise documental } \\
\text { Quem, O que, } \\
\text { Onde, Quanto? }\end{array}$ & Não & Sim/Não \\
História & Como, Por quê? & Não & Não \\
Estudo de Caso & Como, Por quê? & Não & Sim \\
\hline
\end{tabular}

Fonte: YIN, R. K. Case Study Research; design and methods, Sage Publications, v.5, Sage Publications, London New Delghy 1989, p. 17.

Observando essa tabela, nota-se que cada uma das estratégias, em relação a cada um dos critérios, possui determinadas características. No estudo de caso, há três critérios onde o primeiro fixa as questões "como" e "por quê", sendo mais genérica, pois o propósito primordial nessa estratégia é a investigação com maior amplitude, não se preocupando com a freqüência de ocorrência do fenômeno.

O segundo critério no estudo de caso, embora haja uma análise histórica que é apenas contextual, evidencia uma preferência pela análise de eventos contemporâneos.

Quanto ao terceiro critério, não existe manipulação do comportamento humano, porém, pode ocorrer a manipulação informal, pois uma das técnicas utilizadas no estudo de caso é a observação participante. 
Assim, partindo das três condiçōes de definição de estratégias no estudo de caso delineadas por Yin (1989) como um modelo de pré-condições para utilização das principais técnicas disponiveis na realização de pesquisas em ciências sociais, as questões básicas são como? e por quê?

O estudo de caso pode ser entendido como uma investigação que analisa fenômenos contemporâneos dentro de seu contexto real, onde o fenômeno e este não são claramente evidenciados.

Dessa forma, as questões a ser respondidas "como" e "por quê" neste estudo são apresentadas da seguinte forma: Como a agência ambiental do Estado de São Paulo estrutura e desenvolve as atividades de marketing e comunicação influenciando o comportamento da sociedade?

Quanto à segunda questão relativa ao grau de controle que o pesquisador tem sobre eventos comportamentais, a resposta é não, uma vez que na estratégia de estudo de casos não é contemplada a manipulação do comportamento dos indivíduos que estão tomando decisōes de marketing num contexto real da empresa.

Em relação à terceira questão sobre o foco em eventos contemporâneos ou históricos, a resposta é sim, pois embora o foco do estudo de caso esteja voltado para eventos contemporâneos que para ser 
compreendidos, necessitam ser contextualizados pela leitura que os agentes em ação fazem do passado.

Em pesquisas exploratórias, Seltiz et al. (1975) recomendam três estratégias: "(1) uma resenha da ciência social afim e de outras partes pertinentes de literatura; (2) um levantamento de pessoas que tiverem experiência prática com o problema a ser estudado; (3) uma análise de exemplos que 'estimulem a compreensão'. Quase todos os estudos exploratórios utilizam uma ou várias dessas abordagens."

Lembrando que algumas críticas se fazem necessárias quanto ao uso do estudo de caso, que apontam vantagens e desvantagens de acordo com a visão dos autores pesquisados em relação a sua utilização.

\section{VANTAGENS:}

- Simplicidade e economia, podendo ser realizado por um único investigador;

- Estímulo a novas descobertas, análise exaustiva de um determinado fenômeno;

- Énfase na totalidade analisando o fenômeno em profundidade e sob uma perspectiva abrangente, proporcionando uma capacidade mais consistente de compreensão da realidade;

- Simplicidade de procedimentos (coleta e análise de dados), observando que não se deve confundir simplicidade com falta de rigor cientifico; 
- Geração de idẻias que visam encontrar variáveis mais relevantes ou idéias sobre o fenômeno para ser usadas em pesquisa mais ampla.

\section{DESVANTAGENS}

- Críticas em sua utilização considerando principalmente a falta de rigor metodológico;

- Dificuldades de generalizar resultados;

- Gera massa grande de documentos sem conteúdo.

As limitações do estudo de caso podem ser contornadas, contanto que o pesquisador utilize de forma correta e respeite as limitações do método. É imprescindivel preparar um protocolo de pesquisa contendo os procedimentos a ser seguidos, relacionando as atividades a ser realizadas, visando documentar e orientar o trabalho de forma correta.

O estudo de caso, conforme autores pesquisados, constituise em uma estratégia de pesquisa que trata a realidade a partir de uma visāo holística, de forma profunda e exaustiva com a preocupação de delinear um planejamento de pesquisa que obtenha validade e confiabilidade, que são caracteristicas intrinsecas à pesquisa, possibilitando, dessa forma, verificar todos os inter-relacionamentos que ocorrem entre os fatores estruturais e comportamentais do fenômeno estudado.

Assim, segundo os critérios defendidos por Yin (1989), e as orientações dos autores pesquisados, entende-se que o estudo de caso 
constitui-se na técnica mais adequada para o pesquisador utilizar nesse trabalho, por melhor se aplicar à natureza e aos objetivos da pesquisa, pois possibilita um estudo aprofundado e detalhado da realidade social, uma vez que há poucos estudos teórico-empíricos conhecidos na literatura sobre o tema aqui tratado.

A relação comparando o compromisso entre a integridade dos dados e a aceitação dos resultados direciona mais uma vez para o método de estudo de caso como o mais adequado para a pesquisa empírica.

Outra razão da escolha do estudo de caso é o fato da "Operação Rodízio da CETESB" ser o único caso real encontrado pelo autor que relaciona o marketing social e a questão ambiental na administração pública, o que dessa forma direciona o método de pesquisa para o estudo de caso, de acordo com Campomar (1991).

"O estudo de casos envolve a análise intensiva de um número relativamente pequeno de situações e, às vezes, o número de casos reduz-se a um... estudo intensivo de um caso permite a descoberta de relações que não seriam encontradas de outra forma, sendo as análises e as inferências em estudos de casos feitas por analogia de situações, respondendo principalmente às questões por quê? e como?" 
Por essas razões, o autor optou por escolher o estudo de caso como método de pesquisa.

\subsection{ESTUDO DE CASO - DESIGN DA PESQUISA}

Para a eficácia de um estudo da realidade, é necessário compreender o que está sendo estudado, porém na maioria das vezes, a intenção do pesquisador é partir logo para a coleta de dados, sem perceber a importância do papel da construção teórica que deve servir como um guia para a coleta de dados.

Yin (1989) ressalta que para o delineamento da pesquisa é necessário uma série de passos metodológicos na preparação e na condução de estudo de caso, sendo que o primeiro passo é o de elaborar um projeto de pesquisa, depois a coleta e a análise das evidências e, por fim, a composição de um relatório de estudo de caso.

Na visão do autor, o projeto deve conter cinco componentes no delineamento da pesquisa:

1- As questões de estudo;

2- As proposições de estudo, se houver alguma; 
3- Sua(s) unidade(s) de análise;

4- A lógica ligando os dados e as proposiçōes; e

5- Os critérios para interpretar os resultados.

Cada estratégia de pesquisa possui formas próprias de formular questões, conforme visto anteriormente na escolha do estudo de caso. Como estratégia de pesquisa, as questōes mais apropriadas são como e por quê. Neste estudo, a questão é:

Como o Estado de São Paulo, através da sua agência ambiental, estrutura e desenvolve as atividades de marketing e comunicação influenciando o comportamento da sociedade?

Na visão de Yin (1989), a segunda etapa é derivada da primeira (questões de pesquisa). $O$ autor entende que as proposições do estudo, a partir da abordagem teórica, é que vão estabelecer a direção do estudo e a racionalidade que explica o fenômeno, refletindo a resposta esperada à pergunta da pesquisa.

Lembrando que em estudos de natureza exploratória não há hipóteses, então os objetivos e os propósitos do estudo de caso devem ser claramente definidos, assim como os critérios pelos quais serão julgados os resultados. Visando ajudar a alcançar os objetivos da dissertação, considerou-se a capacidade do próprio caso como critério de julgamento. 
A terceira etapa constitui a definição da(s) unidade(s) de análise, definida(s) em decorrência das questōes iniciais da pesquisa, que deverāo decidir se o estudo será um único ou múltiplos casos. A unidade pode ser um ou diversos individuos como um estudo de múltiplos casos, sendo de natureza global (holistic), abrangendo como um todo os elementos do caso ou de natureza encaixada (Embedded), ou seja, dentro do caso abrangendo vários niveis. $O$ caso pode ser realizado em uma entidade, como decisões, programas, processos de implementação ou mudanças organizacionais.

No caso estudado, visando responder às questões do estudo, foram feitos recortes, como:

- Organização de marketing

- Os executivos responsáveis pelas decisões de marketing

- Processo de comunicação das açōes da Operação Rodízio

A ligação dos dados e proposições de estudo pode ser feita de várias maneiras, ressaltando que o pesquisador precisa estabelecer um encadeamento lógico do problema de pesquisa até as conclusões do trabalho. Yin (1989) ressalta a idéia do modelo de correspondência (patternmatching), onde várias partes de informações de um mesmo caso podem se relacionar utilizando algumas proposições teóricas. 
A quinta etapa sobre os critérios de interpretação dos resultados é estabelecida partindo de técnicas específicas, e o pesquisador estrutura as informações sistematizando e analisando os dados primários e secundários, objetivando responder as perguntas que orientam $\circ$ trabalho. A técnica de análise de dados será discutida adiante.

\section{TIPOS DE DESIGN}

Partindo de uma matriz $2 \times 2$ desenvolvida por Yin (1989), pode-se identificar quatro tipos de designs de estudos de caso combinando caso único ou múltiplo, e nestes dois tipos, holístico ou fixado, características da unidade de análise, conforme segue na figura 10.

\begin{tabular}{|c|c|c|}
\hline & $\begin{array}{c}\text { DESIGN } \\
\text { DE CASO ÚNICO }\end{array}$ & $\begin{array}{l}\text { DESIGN DE } \\
\text { MÚLTIPLOS CASOS }\end{array}$ \\
\hline $\begin{array}{c}\text { HOLÍSTICO } \\
\text { (Unidade de Análise } \\
\text { Simples) }\end{array}$ & TIPO 1 & TIPO 3 \\
\hline $\begin{array}{c}\text { FIXADO } \\
\text { (Unidade de Análise } \\
\text { Múltipla) }\end{array}$ & TIPO 2 & TIPO 4 \\
\hline
\end{tabular}

FIGURA 10: Tipos básicos de design para estudo de casos Fonte: $\quad$ Yin (1989)

Observando a matriz desenvolvida por Yin(1989), pode-se verificar que as estratégias podem ser delineadas em único caso holístico, único caso fixado, múltiplos casos holísticos e múltiplos casos fixados. $O$ 
delineamento chamado de fixado ocorre quando o foco de pesquisa analisa os subsistemas que integram um fenômeno, enquanto que o holistico analisa de forma global, ao contrário do anterior.

Convém observar que cada caso individual pode ser holístico ou fixado, tanto no desenho de único caso como no de múltiplos casos, porém a análise do delineamento de múltiplos casos holístico é feita de forma agregada, partindo dos resultados de todos os dados originários das subunidades. A análise dos resultados do delineamento de múltiplos casos fixado ocorre por subunidades dos casos.

A escolha do design em único caso pode ser utilizada em três situações em que o caso representa um caso crítico, reunindo condições que permitam ao pesquisador testar certa teoria; caso extremo ou único, onde acontece uma situaçāo extremamente rara. E sua descoberta torna-se digna de análise, utilizada em situações psicológicas. O caso revelatório é muito usado quando o pesquisador, que faz parte do fenômeno, observa e analisa um fenômeno inacessivel à investigação científica.

Podemos ilustrar o delineamento do estudo de único caso conforme segue figura 11. 


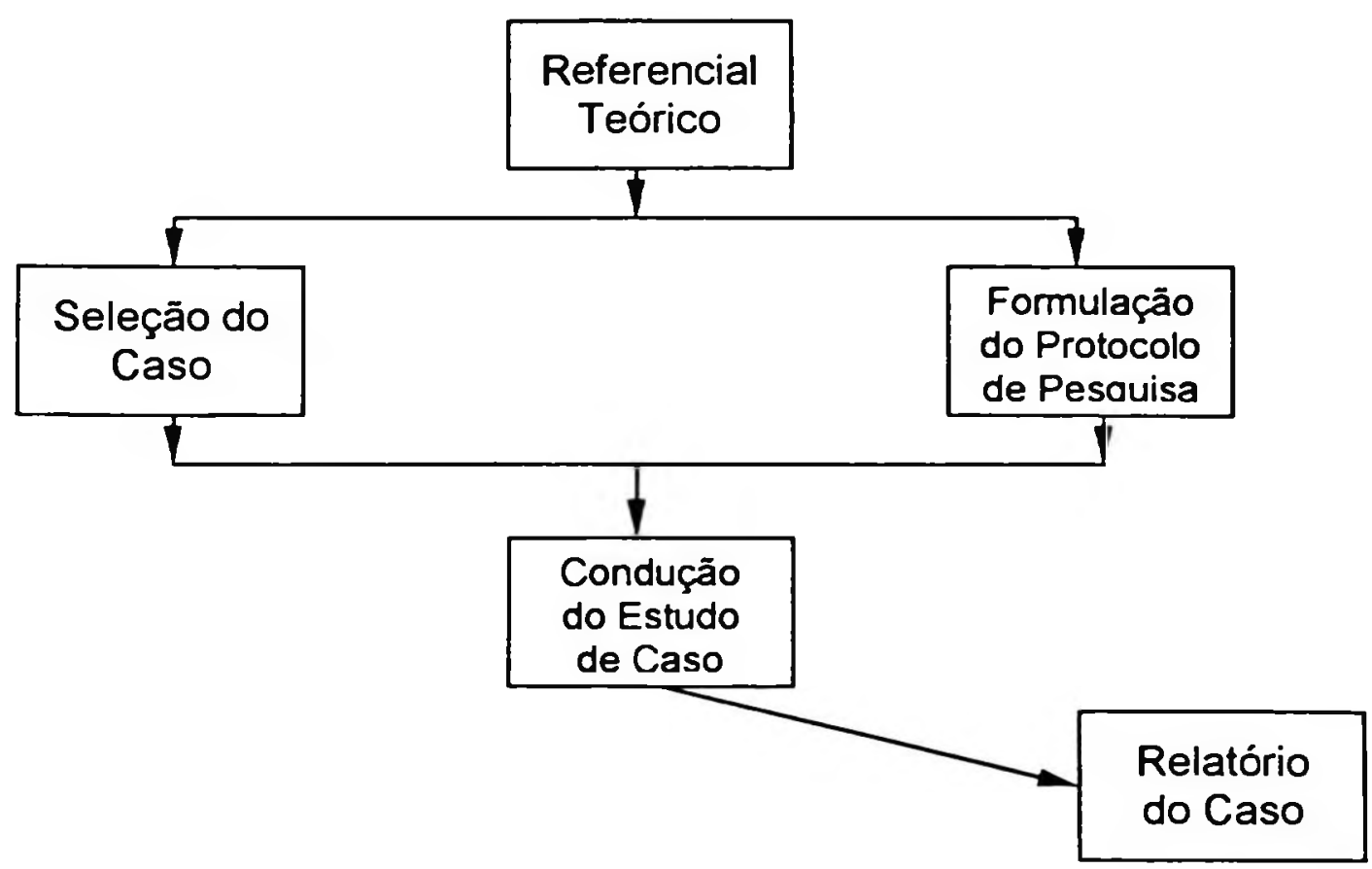

FIGURA 11: Delineamento de estudo de único caso

Fonte: $\quad$ Adaptada de Yin $(1989, \mathrm{p} 56)$

Observando a figura 11 , nota-se que o estudo inicia com o desenvolvimento de um referencial teórico, relatando as teorias existentes na área de estudo e os estudos teóricos anteriores, partindo das questōes de pesquisa.

Feita essa etapa, as ações são desenvolvidas em dois niveis nos quais seleciona-se o caso, justificando a razão da escolha para aquele tipo de estudo, e formula-se o protocolo de pesquisa onde o pesquisador define como será a operacionalização do processo.

A condução do estudo de caso é relativa à coleta e análise dos dados, realizando análise documental, observaçōes e aplicação de 
entrevistas, que por fim termina com a elaboração de um relatório de pesquisa, lembrando que no desenvolvimento dessas etapas, o pesquisador utiliza técnicas específicas.

Quando um mesmo estudo contém mais do que um caso, a escolha do design do estudo é chamada de múltiplos casos. Utilizado quando há possibilidade ou necessidade de se empregar mais de um caso no design da pesquisa, podendo também ser aplicado como experimento em situações em que ocorram testes da teoria e eventos que testem teorias contrárias (replicação literal e teórica).

Para desenvolver esta dissertação, o design selecionado foi o de único caso com uma única unidade de análise (holística), considerando ser a Operação Rodizio da SMAVETESB como proteção ambiental o único caso encontrado no Brasil abordando esse processo, e haver poucos casos relatados e literatura relacionando a aplicação do marketing social com a questão ambiental na administração pública, focando a comunicação persuasiva. 


\subsection{DESENVOLVIMENTO DO PROTOCOLO DO ESTUDO DE CASO}

Segundo Yin (1989), "o protocolo do estudo de caso é mais que um instrumento. O protocolo contém o instrumento mas também contém - procedimento e regras gerais que devem ser seguidas no uso do instrumento". Na visão do autor, o protocolo visa solucionar a lógica de ligação entre as proposições e os dados, e os critérios para interpretar os achados, aumentar a confiabilidade e validade do trabalho do pesquisador, devendo conter preferencialmente as seguintes seçōes:

- "Visão geral do projeto de estudo de caso;

- Procedimentos de campo (vias de acesso aos locais do estudo, fontes gerais de informações sobre o caso $e$ procedimentos previstos de coleta de dados);

- Questões do estudo de caso (questões especificas apresentadas no instrumento de coleta de dados, tabelas para arranjos de dados, e fontes potenciais de informação para resposta de cada questão);

- Guia para o relatório do estudo de caso (resumo, formato para a narrativa, e especificação de alguma informação bibliográfica e outra documentação)" Yin (1989).

Em estudos de natureza exploratória, deve-se ter um cuidado constante ao coletar evidências de forma planejada, lembrando que 
as entrevistas são menos estruturadas, e o investigador se envolve em situaçōes diferentes. $O$ entrevistado pode desconhecer alguns detaihes do caso e abster-se de responder as questões. O investigador deve estar atento observando os fatos e deles extrair informações que complementem ou acresçam seu estudo.

Portanto, é necessária a elaboração de um guia bem planejado e explícito para orientar as atividades de campo, sendo suficientemente flexivel para lidar com as situaçōes inesperadas e sofrer ajustes de acordo com o seu desenvolvimento.

Objetivando estabelecer critérios para julgar a qualidade de projetos de pesquisa que englobam validade e confiabilidade em estudos de casos, Yin (1989) sugere algumas táticas, como utilizar fontes múltiplas de evidência, estimulando durante a coleta de dados linhas convergentes de investigação, estabelecendo uma rede de evidências; e solicitar aos informantes-chave que revisem o rascunho do relatório de estudo.

Yin (1989) ressalta alguns tópicos como procedimentos de campo do protocolo, como:

- Estabelecer acesso às organizaçōes-chave ou entrevistados;

- Manter recursos suficientes enquanto estiver no trabalho de campo, incluindo lápis, papel e um lugar adequado para as entrevistas; 
- Desenvolver procedimentos que permitam solicitar auxilio e orientação, se necessário, de outros especialistas ou colegas em estudo de casos;

- Estabelecer uma lista precisa de atividades de coleta de dados com tempo previsto;

- Preparar-se para eventos não previstos incluindo mudanças de horários, humor e motivação dos entrevistados.

O relatório do estudo de caso normalmente é uma parte negligenciada pelo pesquisador que prefere pensar nessa etapa no final, após a coleta de dados. Convém observar que não existe um formato padrão para o relatório do estudo de caso, uma vez que seu formato tem como conseqüência a adequação determinada pelo veículo de publicação, por isso é importante que o pesquisador, durante a conduçāo do estudo, tenha em mente a forma final que terá o relatório.

Porém, a maioria dos experimentos segue uma estrutura similar contendo a descrição do design da pesquisa, instrumentos e procedimentos de coleta, apresentação dos dados coletados e a discussão dos resultados e conclusões do estudo, lembrando que uma das principais vantagens da estratégia de estudo de caso é a flexibilidade que o pesquisador pode ter a partir da coleta inicial de dados, para considerar novos aspectos e insights. Portanto, é fundamental que o formato do relatório esteja explícito no protocolo e que facilite a coleta de dados relevantes, visando minimizar possiveis retornos à instituição para novas entrevistas. 
O protocolo foi desenvolvido antes do trabalho de campo, de maneira mais operacional e clara possivel, sofrendo ajustes de acordo com o seu transcorrer, conforme o suporte teórico permitiu.

\subsection{COLETA DE DADOS}

Em estudos de casos, grande parte dos autores atribui à coleta de dados uma das mais importantes etapas do estudo. Na visão de Castro (1977), para realizar um estudo exploratório, pode-se através, da revisão existente da literatura sobre o tema, consultar a opinião de especialistas e, através de estudo de exemplos, despertar a compreensão do fenômeno.

O pesquisador deve coletar os dados de forma planejada em sua abordagem da realidade, explicitando qual a melhor forma de obtê-los de acordo com a sua necessidade visando responder ao problema da pesquisa, conforme sua indagação, objetivos e estratégia de pesquisa adotada.

Na visão de Mattar (1994) existem quatro fontes básicas de dados diferentes, sendo: 
a) "pesquisado - através de sua própria declaração, verbalmente ou por escrito, ou através de sua observação;

b) pessoas que tenham informações sobre o pesquisado quando ocorre de o pesquisado ser inacessivel.

c) situações similares e

d) dados disponiveis."

Os dados em estratégia de estudo de caso podem ser obtidos de duas fontes classificadas em dois grandes grupos, as secundárias e as primárias.

Segundo Mattar, (1994), os dados primários "são aqueles que não foram antes coletados, estando ainda em posse dos pesquisados, e que são coletados com o propósito de atender às necessidades especificas da pesquisa em andamento", e os dados secundários "...são aqueles que já foram coletados, tabulados, ordenados e, às vezes, até analisados, com propósitos outros ao de atender às necessidades da pesquisa em andamento, e que estão catalogados à disposição dos interessados."

Assim, as fontes primárias são relativas a opiniões, atitudes, comportamentos e valores dos individuos e, portanto, requerem levantamentos que possam revelar com clareza o comportamento e explicar razões desse comportamento, já a secundária são informaçōes nas quais os individuos revelam sua natureza através de documentos. 


\section{A. Dados secundários}

Coletou-se informaçōes através de análise documental, como arquivos através de documentos, cartas, memorandos e outras comunicações, folders, minutas ou outros documentos escritos sobre os eventos, bem como documentos administrativos, propostas de relatórios e outros documentos internos, reportagens e artigos divulgados na mídia.

Levantou-se também a documentação sobre o assunto, como o plano estratégico da CETESB, relatórios de planejamento operacional, pesquisas de mercado realizadas, campanhas desenvolvidas relativas ao ar, reportagem e artigos na mídia, memorandos, atas de reuniōes, material de divulgação produzido e relatórios de atividades realizadas.

\section{B. Dados primários}

Em estudo de caso, alguns autores atribuem como principal técnica de coleta de dados a entrevista em profundidade e a observação participante onde o pesquisador faz parte do estudo de caso, desempenhando papéis e participando do evento que está sendo estudado.

Na visão de Campomar (1991), “O método científico da pesquisa social empírica permite que se faça levantamento, observação e experimento, fornecendo conhecimento sobre opiniōes, atitudes, crenças e 
percepções dos individuos, sejam eles agentes ou pacientes de um processo".

Dessa forma, "O estudo intensivo de um caso permite a descoberta de relações que não seriam encontradas de outra forma, sendo as análises e inferências em estudo de casos feitas por analogia de situações, respondendo principalmente às questões por quê? e como?.(Campomar 1991)

Neste trabalho, as entrevistas foram realizadas em profundidade, do tipo semi-estruturada, com o ex-secretário de Estado do Meio Ambiente, responsável pela coordenação da campanha e membros da equipe técnica de pesquisa e coordenação da divulgação da "Operação Rodizio".

\subsection{FONTES DE INFORMAÇÃO}

Mattar (1994) aponta como fontes básicas de dados primários: o pesquisado, pessoas que tenham informações sobre o pesquisado e situaçōes similares, e em dados secundários: a própria empresa, publicaçōes, governos, instituições não governamentais. 
Seltis et al. (1975) complementam que existem outras fontes, além de registros estatísticos e documentos autobiográficos, como as matérias destinadas à comunicação de massa, e dizem.

"Esse material pode aparecer sob a forma de criações literárias, jornais, revistas ou, mais recentemente, como fitas de cinema ou programas de rádio e televisão.

Os documentos de comunicação de massa não são criados para o pesquisador, e sob esse aspecto (embora não sob outros) estão livres da influência de seu viés teórico ou pessoal......os documentos de comunicação de massa refletem aspectos amplos do clima social em que foram criados."

Segundo Yin (1989), as fontes de dados podem ser originadas de seis principais fontes, como documentação, registros em arquivos, entrevistas, observação direta, observação participante e artefatos físicos.

Conforme recomendações dos autores pesquisados, nesta dissertação, os dados foram coletados da seguinte forma:

- Dados Primários: foram realizadas entrevistas de forma semi-estruturada e não disfarçada, focalizadas, pessoais e individuais com o secretário de 
Estado do Meio Ambiente da gestão 1995 a 1998 e com outros profissionais diretamente ligados à "Operação Rodizio";

- Dados Secundários: coletados por meio de diversas fontes internas e externas, como documentos, arquivos, registros da SMACETESB, livros e outras publicaçōes ligadas direta ou indiretamente ao tema abordado, como:

1. Documentos: memorandos, cartas e outras comunicaçōes

- Documentos administrativos, relatórios, propostas, atas de reuniōes, circulares, enfim, documentos internos;

- Folders e outras peças de divulgação utilizadas;

- Reportagens, clipping e outros artigos divulgados na mídia;.

- Release enviado aos veículos de comunicação;

- Relatórios (técnicos e administrativos), como planejamento estratégico e operacional, pesquisas de mercado.

2. Arquivos: Podem ser informatizados ou físicos, através de:

- Registros de serviços, como o atendimento à população, como exemplo, foi criada uma unidade especifica para prestar esclarecimentos e atender reclamaçōes da comunidade e um serviço de telemarketing específico para a "Operação Rodízio";

- Mapas e quadros de determinadas regiöes com caracteristicas geográficas, populacionais, etc;

- Cadastros e listas contendo outras informaçōes; 
- Levantamentos com registros e dados previamente coletados.

3. Artefatos Físicos: é uma fonte não muito usual em estudos administrativos, que podem ser equipamentos tecnológicos, objetos, obra de arte, etc.

Neste trabalho de dissertação, utilizou-se, na coleta de dados primários, entrevistas focadas de forma semi-estruturada e não disfarçada e não participante, com o executivo responsável e outros profissionais ligados à "Operaçăo Rodizio", visando verificar opiniōes e atitudes dos indivíduos em relação às atividades de marketing desenvolvidas no processo.

Os dados secundários foram coletados por meio de levantamento em fontes internas e externas, basicamente analisando-se documentos e arquivos, como registros e relatórios, artigos, livros, release e resenhas publicadas na mídia impressa em geral e outras publicações de organizações ligadas direta ou indiretamente ao processo da "Operação Rodizio". 


\subsection{ANÁLISE DOS DADOS}

Em estudo de caso com natureza exploratória, não há hipóteses, e portanto Yin (1989) observa que devido ao fato de não haver fórmulas ou receitas para realizá-lo, a exemplo das análises estatísticas, a análise de dados é um dos aspectos menos desenvolvidos e o de mais difícil operacionalização.

Assim, as análises devem ser feitas por analogias, contendo comparações com teorias, modelos e outros casos, que segundo Campomar (1991), "as conclusões deverão ser especificas com possiveis inferências (não estatísticas) e explicações permitindo que as generalizações sejam usadas como base para novas teorias e modelos."

Yin (1989) identifica duas estratégias genéricas de análise em estudo de caso que auxiliam o pesquisador na escolha de diferentes técnicas, sendo as estratégias a de proposições teóricas e a de descrição do caso. $\mathrm{O}$ autor formula ainda três técnicas principais analiticas; o encaixe de um padrão ou modelo de correspondência, construção de explicação e análise de séries temporais que podem ser utilizadas como parte de uma das duas estratégias genéricas.

Segundo o autor, em estudos de caso, a Estratégia das Proposições Teóricas é a mais utilizada. Partindo das proposiçōes teóricas, 
espelha as questões de pesquisa, revisão da literatura e novos insights de pesquisa. As proposições orientam e guiam a coleta e análise de dados, contribuindo também para o aperfeiçoamento da realidade que é considerada como a maior riqueza do estudo de caso por permitir um aprofundamento a partir de um referencial teórico.

Ainda segundo o autor, na técnica analítica de Encaixe em um Padrão ou Modelo de Correspondência, o pesquisador compara um modelo empirico com um modelo teórico. Se o estudo de caso for do tipo exploratório, pode-se relacionar o modelo com as variáveis dependentes e/ou independentes, mas se o estudo caracterizar-se como descritivo, então o padrão pode ser estabelecido apenas para a variável independente.

Nesta dissertação, a análise dos dados foi realizada com base na estratégia das proposiçōes teóricas e na técnica analítica de encaixe de um padrão.

\subsection{RELATÓRIO DE PESQUISA DO ESTUDO DE CASO}

Segundo Selltiz et al. (1975), antes da apresentação escrita do relatório, a tarefa da pesquisa não se completa, e lembra que durante a redação, o mais importante em sua função é que "...o objetivo de um relatório não é a comunicação consigo mesmo, mas com o público". 
A autora enfatiza que a comunicação com o público exige um conhecimento sobre a que tipo de leitor se destina o relatório, e independente do tipo de público, se específico ou geral, duas questōes devem ser consideradas: o que o público deseja ou precisa saber a respeito do estudo e qual a melhor forma de apresentar essa informação.

Tanto Yin (1989) como Selltiz et al. (1975) recomenda que o pesquisador antecipadamente pense na forma como o relatório deve ser escrito, baseado nas caracteristicas do público a ser direcionado. Outra questão apresentada na literatura é a do pesquisador pensar antecipadamente em qual forma terá o relatório, ao mesmo tempo permitindo e reconhecendo que essa tarefa mais depende do conhecimento adquirido no próprio estudo do que da proposta inicial de formatação do relatório, ou seja, a forma do relatório que mais faça sentido após o conhecimento dos resultados.

Selltiz et al. (1975) justificam argumentando, "um estudo não está totalmente cristalizado quando se formula o problema de pesquisa. Durante a pesquisa, pode criar-se uma apresentação mais adequada do problema, novas hipóteses podem surgir, relaçōes não previstas podem aparecer. Por isso, embora a formulação original apresente o aspecto básico de referência para o relatório, deve também haver lugar para a inclusão de desenvolvimentos posteriores". 
Resumindo, năo importa o formato do relatório, apesar de ele ser uma condição de sua qualidade, mas sim o conteúdo de suas informações e a capacidade contida nele de transmitir conhecimento sobre 0 problema em estudo para o público destinado.

Uma procedimento para aumentar a qualidade do trabalho, partindo de documentos e depoimentos, é o pesquisador apresentar aos informantes e participantes do trabalho uma versāo do relatório para que possam confirmar, criticar, comentar e até discordar de conclusōes e fatos apresentando novas versōes e evidências relatadas pelo pesquisador, possibilitando que o trabalho seja ampliado.

Na visão de Selltiz et al. (1975), um relatório de pesquisa deve abranger os seguintes aspectos:

1. "Apresentação do problema a que se refere o estudo;

2. Os processos da pesquisa; o planejamento do estudo, o método de controle da variável independente, no caso de o estudo ter a forma de um experimento, a natureza da amostra, as técnicas de coleta de dados, o método de análise estatística;

3. Os resultados;

4. As conseqüências dos resultados." 
Quanto à estrutura de relatórios de pesquisa, Yin (1989) ressalta que depende do propósito do estudo (exploratório, descritivo ou causal) para definir qual a melhor estrutura a ser utilizada pelo pesquisador, e apresenta seis estruturas que permitem que capitulos, seçōes, subtópicos e outros componentes sejam ordenados de forma lógica, conforme segue no quadro 3.

\begin{tabular}{|l|c|c|c|}
\hline \multirow{2}{*}{\multicolumn{1}{|c|}{$\begin{array}{c}\text { Tipos de } \\
\text { Estrutura }\end{array}$}} & \multicolumn{3}{|c|}{$\begin{array}{c}\text { Propósito do Estudo de Caso } \\
\text { (simples ou múltiplos casos) }\end{array}$} \\
\cline { 2 - 4 } & Causal & Descritiva & Exploratória \\
\hline Analítico-Linear & $\mathrm{X}$ & $\mathrm{X}$ & $\mathrm{X}$ \\
Comparativa & $\mathrm{X}$ & $\mathrm{X}$ & $\mathrm{X}$ \\
Cronológica & $\mathrm{X}$ & $\mathrm{X}$ & $\mathrm{X}$ \\
Construção de Teoria & $\mathrm{X}$ & & $\mathrm{X}$ \\
Suspense & $\mathrm{X}$ & & $\mathrm{X}$ \\
Nāo Seqüencial & & & \\
\hline
\end{tabular}

QUADRO 3: Tipos de estrutura de relatórios de estudo de casos Fonte: $\quad$ Yin $(1989$, p.137)

Nesta dissertaçāo, para apresentação do relatório de pesquisa, utilizou-se a estrutura analitico-linear comparando as estruturas apresentadas por Yin, considerada uma abordagem-padrāo para a composição de relatórios de pesquisa, que permite ser utilizada em estudos de caso exploratórios, descritivos ou causais, e sua metodologia de 
apresentação de resultados torna mais clara e lógica a apresentação e o desenvolvimento dos argumentos do pesquisador.

A seqüencia de tópicos consiste em apresentação da questão que está sendo investigada, o método utilizado, os resultados da coleta e análise dos dados e as conclusōes e recomendações do estudo. No trabalho de campo, as visōes dos entrevistados foram comparadas com as do pesquisador, sendo apresentadas de forma resumida no relatório de estudo do caso.

O protocolo detalhado contendo todos os procedimentos encontra-se no próximo capítulo desta dissertação. 


\section{CAPÍTULO 4 - PROCEDIMENTOS - ESTUDO DO CASO "OPERAÇÃo RODÍZIO"}

No capitulo anterior, discutimos os principais aspectos do planejamento formal que orientou a pesquisa de campo a ser apresentada neste capítulo: a forma como foram conduzidos os procedimentos na Operação Rodizio.

Na execução dessa tarefa, é necessário que o estudo possua um protocolo, instrumento metodologicamente confiável contendo a forma e o conteúdo das atividades planejadas para esse fim, e que através da reprodução de suas etapas, possibilite a quem quiser realizar o mesmo estudo chegar a resultados semelhantes.

Em complemento a este capítulo, são apresentadas as razōes que justificaram a escolha da SMACETESB como alvo inicial do estudo. E, em complemento, a Operação Rodizio como o caso contemplado para o estudo. Por fim, é realizada a análise dos dados coletados.

Ressalta-se que o foco da pesquisa, conforme mencionado anteriormente no problema de pesquisa, visa estudar o processo de comunicação da Operação Rodizio, ou seja, as atividades de comunicação 
persuasiva desempenhadas nessa unidade de análise e não nas empresas como um todo. É importante observar que é impossivel separar a unidade de processo do conjunto organizacional.

Outro aspecto que merece destaque é o instrumento de coleta de dados primários, isto é, o roteiro de entrevistas que foi elaborado de forma a buscar, sempre que possivel, uma resposta precisa sobre o fato em estudo, visando evitar um possivel viés analítico decorrente da interpretação do pesquisador em relação ao conteúdo das questões abertas, que normalmente são abrangentes. Enfim, permitindo observaçōes e complementações pertinentes ao assunto por parte do pesquisador e do pesquisado.

Nesta dissertação, o protocolo foi constituido de quatro seções:

- visão geral do estudo de caso,

- procedimentos de campo,

- análise dos dados e

- relatório do estudo de caso.

O capítulo 5 aborda a análise dos dados junto ao relatório do estudo de caso. Segue PROTOCOLO da "OPERAÇĀO RODIZZIO". 


\subsection{PROTOCOLO DE PESQUISA DA OPERAÇÃO RODIZIO}

\subsubsection{VISÃo GERAL dO ESTUdO dE CASO}

- TEMA: Uso da comunicação persuasiva no marketing social em instituições não lucrativas abordando a conscientização das questões ambientais na sociedade.

- TítUlo: Aspectos do uso da comunicação persuasiva no marketing social: O caso da Operação Rodízio para proteção ambiental.

- PRESSUPOSTO: De forma geral, o marketing social é um conceito pouco utilizado no Brasil, principalmente pelas empresas públicas que nem sempre utilizam a comunicação persuasiva como recomenda a teoria, objetivando atender às necessidades $e$ aos desejos da comunidade de forma plena, conscientizando e assegurando uma melhor qualidade de vida da coletividade sobre questōes da proteção ambiental.

- PRoblema de PESquisa

Qual a situação das atividades de marketing e de comunicação na Agência Ambiental do Estado de São Paulo (SMACETESB)? Como estas atividades influenciam o relacionamento com 
a sociedade? E como é feito o processo de comunicação, especificamente no caso da "Operação Rodízio"?

- OBJETIVO do ESTUdO

Partindo desse problema de pesquisa, o objetivo a ser alcançado é analisar o conceito e as atividades de comunicação persuasiva de marketing social e sua aplicabilidade em uma realidade empirica, identificando quais são as atividades desenvolvidas pela agência ambiental do Estado de São Paulo (SMACETESB) no processo de comunicação e, especificamente, no caso da Operação Rodízio.

- PERGUNTAS DA PESQUISA:

Visando atender ao propósito central deste trabalho, formulou-se as seguintes perguntas:

- Qual o conceito de marketing social e comunicação persuasiva?

- Quais são as atividades do marketing social?

- Como é estruturado o marketing social na SMAVCETESB na Operação Rodizio?

- As atividades de comunicação da SMAVETESB no caso especifico da Operação Rodizio estão de acordo com a teoria de marketing social? 


\section{- PROPOSIÇÕES TEÓRICAS:}

Nesta dissertação, procurou-se analisar a utilização das principais dimensões conceituais do marketing social, enfatizando a comunicação persuasiva no processo de um programa de Governo voltado para a conscientização pública quanto à proteção ambiental. $O$ enfoque teórico foi dividido em revisão dos conceitos de marketing e do marketing social e comunicação persuasiva.

\section{- estrutura do trabalho}

- Introdução:

- Capítulo 1: Justificativa e descrição do problema de pesquisa.

- Capítulo 2: Revisão bibliográfica do tema marketing social e comunicação persuasiva.

- Capítulo 3: Planejamento da pesquisa.

- Capítulo 4: Procedimentos - Estudo do caso "Operação Rodízio".

- Capítulo 5: Caso do programa de restrição à circulação de veículos automotores na região metropolitana - "Operação Rodízio 1995 a $1998^{\prime \prime}$

- Capítulo 6: Conclusões, recomendaçōes e limitações.

- Bibliografia.

- Anexos. 
- PESSOAL ENVOLVIDO

- Pesquisador $\quad$ : Ricardo Marcelo Giacon

- Professora Orientadora: Profa. Dra. Ana Akemi Ikeda

- ORGANIZAÇÕES ENVOLVIDAS

- Patrocinadora : Universidade de São Paulo

- Empresas do caso: SMA - Secretaria do Estado do Meio Ambiente (Estado de São Paulo) e CETESB - Companhia de Tecnologia de Saneamento Ambiental

\subsubsection{PROCEDIMENTOS NO TRABALHO DE CAMPO}

- ASPECTOS METOdOlógicos: A pesquisa foi caracterizada como exploratória optando-se pela estratégia do estudo de caso, cujo tipo de estudo selecionado foi o de único caso com uma única unidade de análise (holística).

- EMPRESAS DO CASO: As empresas escolhidas para o estudo de caso foram a Secretaria Estadual do Meio Ambiente e a Companhia de Tecnologia de Saneamento Ambiental 
- UNIDADE DE ANÁLISE: Foi selecionado o Programa de Restrição à Circulação de Veículos Automotores na Região Metropolitana ("Operação Rodízio 1995 a $1998^{\prime \prime}$ ), único programa encontrado no Brasil para atender ao objetivo de pesquisa de campo. O programa é um dos poucos casos relacionados à aplicação do marketing social e à questão ambiental na administração pública, focando a comunicação persuasiva como proteção ambiental.

- COLETA DE DADOS: Foi efetuada de duas formas utilizando-se fontes primárias e secundárias.

\section{$\checkmark$ FONTES DE DADOS:}

- PRIMÁRIAS: Foi o estudo das situações de como as empresas do caso organizavam as atividades de marketing social e operavam a comunicação persuasiva. A forma de conhecer essa situação foi por meio do estudo de único caso com uma única unidade de análise (holistica).

- SECUNDÁRIAS: Os dados foram coletados a partir dos seguintes instrumentos:

- Internos: Documentos, relatórios, publicações, arquivos e registros internos, material impresso, clipping, folder e outros materiais produzidos para divulgação. 
- Externos: Livros, artigos e outras publicações produzidas por organizações ligadas direta ou indiretamente à unidade de análise, bem como resenhas publicadas na midia especializada e impressa em geral.

\section{- INSTRUMENTOS DE COLETA DE DADOS:}

- PRIMÁRIAS: A coleta de dados foi realizada por meio da aplicação de uma entrevista focada, pessoal e individual com o exsecretário do Estado do Meio Ambiente, responsável pela coordenação da campanha no período de 1995 a 1998, e com outros profissionais membros da equipe técnica de pesquisa e coordenação da divulgação da "Operação Rodízio" no periodo analisado.

- Entrevistados:

- Sr. Fabio Feldmann - Ex-Secretário do Meio Ambiente.

- Sra. Eli Serenza - Assessora de Comunicação do Rodízio

- Sra. Vera Lúcia Sanchez Cezaretto - membro da equipe de Coordenaçāo Executiva da pesquisa do infrator do rodizio.

Elaborou-se o roteiro de entrevista com o intuito de levantar e verificar dados primários e opinião dos entrevistados sobre o desenvolvimento do conceito das atividades de marketing desenvolvidas na Operação Rodízio, que não puderam ser analisadas através das diversas 
fontes secundárias (internas e externas) utilizadas, como relatórios, documentos e outros. O roteiro aplicado de entrevistas na Operação Rodízio encontra-se no anexo.

\subsubsection{AS QUESTÕES DO ESTUDO DE CASO :}

As questões respondidas pelo estudo foram as seguintes:

- PROBlema de PESQUISA

Qual a situação das atividades de marketing e de comunicação na Agência Ambiental do Estado de São Paulo (SMAVCETESB), e como estas atividades influenciam o relacionamento com a sociedade e como é feito o processo de comunicação, especificamente no caso da "Operação Rodízio".

- PERGUNTAS DA PESQUISA:

1. Qual o conceito de marketing social e comunicação persuasiva?

2. Quais são as atividades do marketing social?

3. Como é estruturado o marketing social na SMACETESB na Operação Rodízio? 
4. As atividades de comunicação da SMAVCETESB no caso especifico da Operaçāo Rodízio estão de acordo com a teoria de marketing social?

O trabalho de campo visou buscar respostas para as questões 3 e 4 baseadas nas dimensões teórico-operacionais.

\subsubsection{ANÁLISE DOS DADOS}

Análise de dados foi desenvolvida comparando-se a teoria e uma situação real, com base na estratégia das proposições teóricas e na técnica analítica de encaixe de um padrāo.

Essa técnica é baseada na comparaçāo de um padrão conceitual definido anteriormente ou de vários padröes alternativos comparados com um padrão obtido na realidade.

$\mathrm{Na}$ presente dissertaçāo, foram inseridas as principais dimensões teórico-conceituais sobre o marketing social e a comunicação persuasiva, ambos analisados de que forma foram utilizados na Operação Rodizio. 


\subsubsection{RELATÓRIO DO ESTUdO DE CASO}

Nesta dissertação, para apresentação do relatório de pesquisa, considerando que a audiência-alvo é constituída de pesquisadores e/ou banca de dissertação/mestrado, utilizou-se a estrutura analítico-linear considerada a abordagem-padrão para a composição de relatórios de pesquisa.

A seqüência de tópicos utilizada nesta dissertação foi a seguinte: apresentação do problema de pesquisa, fundamentação teórica sobre marketing social e comunicação persuasiva, planejamento da pesquisa (metodologia do trabalho), protocolo da pesquisa de campo, apresentação e análise do caso e, finalmente, as conclusões do trabalho. 


\section{CAPÍtUlO 5 - CASO dO PROGRAMA DE RESTRIÇÃO À CIRCULAÇÃo dE VEÍCuLOS AUTOMOTORES NA REGIÃo METROPOLITANA - "OPERAÇÃO RODÍZIO 1995 A 1998”}

Conforme apresentado nos capitulos anteriores, partindo dos conceitos e atividades formulados de marketing, analisou-se o conceito de marketing social e comunicação persuasiva.

Optou-se pelo delineamento do estudo de caso visando confrontar os conceitos discutidos na esfera teórica com a realidade empírica das organizaçōes e analisando a realidade com a teoria. Por se tratar de um tema pouco explorado na literatura, essa interação pode gerar novos insights para a área da administraçāo.

5.1. UM BREVE PANORAMA - GLOBALIZAÇÃO E CONSCIÊNCIA ECOLÓGICA

A idéia de que a natureza existia somente para satisfazer às necessidades e aos desejos humanos prevaleceu por séculos sem 
questionar os limites dos recursos naturais, baseados no consumismo e no desperdício.

Na visão de Leis (1997), criamos um mundo cheio de fronteiras entre homens, povos e espécies, de forma subjetiva, demarcando todo o planeta. Essa visão de fronteira inventada e artificial, não é intransponivel ou definitiva. Através do amor, que o autor afirma existir, as fronteiras são afirmadas e derrubadas permanentemente. $E$ a vida que os humanos compartilham com uma infinita quantidade de outras espécies não pode ser codificada apenas em termos económicos ou políticos.

Vivemos em um mundo cada vez mais globalizado, onde a cidadania vem assumindo uma responsabilidade planetária, conscientizando as pessoas de que a realidade regional é parte integrante de um processo mundial de transformações.

Conforme publicação da SMA, Quem somos e o que fazemos (SMA, 1998), "As expressões 'desenvolvimento ambientalmente sustentável' ou 'desenvolvimento sustentável' não são apenas uma construção de palavras. Significam que o desenvolvimento não pode ser feito a qualquer preço e, muito menos, comprometendo o espaço das cidades ou dos campos. Nossas ações de hoje estão comprometidas com as gerações futuras." 
Rattner (1995) alerta para as políticas adotadas por alguns paises de rápido crescimento econômico, cuja meta do desenvolvimento tem produzido custos sociais e ambientais ocultos e transferidos ou externalizados, comprometendo a qualidade de vida da sociedade.

Este século foi marcado pelo período de maior desenvolvimento tecnológico e econômico da história da humanidade, mas também o que teve a maior degradação ambiental, com impactos negativos na qualidade de vida das populações e da produção econômica. Por isso, as questões ambientais têm permeado o cenário socioeconômico despertando interesse e atenção crescente de empresas, governos e cidadãos.

A Agenda 21 (1997), convocada pela Assembléia Geral das Naçōes Unidas, foi realizada visando elaborar estratégias que permitissem interromper e reverter os efeitos da degradação ambiental e da deterioraçāo do sistema que sustenta a vida do planeta, recomendando aos governos e a vários segmentos da sociedade a prática na qual a atividade humana incide de forma prejudicial ao meio ambiente.

A educação ambiental e a questão da conscientização pública foram abordadas no capítulo 36 da Agenda 21 (1997) enfatizando a importância do ensino formal e informal para modificar as atitudes das pessoas em consonância com o desenvolvimento sustentável, integrando todas as disciplinas e empregando métodos formais e informais, bem como meios efetivos de comunicação. E o capitulo 28 abordou a iniciativa das 
autoridades no processo de estabelecer políticas e regulamentações ambientais locais.

Como base para ação, o capitulo 36 apontou a insuficiência e a inexatidão de informações, sendo necessário sensibilizar o público sobre os problemas ambientais, fazendo-o participar de suas soluções, ressaltando a participação da comunidade local, utilizando os meios de comunicação de massa que devem ser facilitados.

Visando melhorar a qualidade da vida humana dentro dos princípios de uma sociedade sustentável, respeitando e cuidando da comunidade dos seres vivos, através da modificação de atitudes e práticas pessoais, a publicação "Cuidando do Planeta Terra" (Humberg, 1992) ressalta o incentivo e o envolvimento de todos utilizando uma linguagem local, usando toda mídia disponivel e adequando ao público específico.

Assim, agindo em seu próprio espaço, deve administrar e propor soluções para sua realidade imediata, garantindo que órgãos governamentais, setores empresariais e sociedade civil participem da definição de políticas e diretrizes globais, setoriais ou regionais, assumindo a incorporação da dimensão ambiental no processo de tomada de decisões sobre o desenvolvimento.

No processo dinâmico de globalização e modernização da sociedade, os meios de comunicação de massa se desenvolveram de forma 
rápida, tornando-se acessiveis e gerando uma grande demanda de informações aos seres humanos.

A concorrência internacional e a série de normas técnicas ISO 9.000 e 14.000 repercutiram diretamente nas empresas, alterando seu processo produtivo e afetando seus recursos humanos que passaram a adotar uma nova postura.

Nesse processo, os consumidores, mais informados e conscientes, passaram a exigir produtos com preços menores e maior qualidade sem agredir o meio ambiente, aumentando a conscientização sobre as causas ecológicas por parte da população.

Pesquisas têm indicado que o grau de conscientização sobre as causas ecológicas por parte da população tem aumentado e que a população atribui ao Governo a maior responsabilidade pela proteção e ações em relação à preservação ao meio ambiente, lembrando que o Governo tem grande importância e atuação na economia do País e em seu desenvolvimento.

Conforme Crespo (1997) em pesquisa desenvolvida sobre "O que o brasileiro pensa sobre o meio ambiente", que compara dados obtidos em 92 com os 97 , em seu resultado foram destacados alguns pontos relevantes, como: 
- Há significativa consciência ambiental, embora o brasileiro se considere pouco informado sobre questões relativas ao meio ambiente;

- O nivel de informação do brasileiro sobre problemas ambientais cresceu pouco, e 95\% alegam nunca ter ouvido falar da Agenda 21;

- $80 \%$ da população brasileira têm grande simpatia pelas organizações que atuam e trabalham na defesa do meio ambiente;

- Diminuição da responsabilidade atribuída à esfera federal e aumento da mesma aos municípios, com apoio à descentralização e valorização de ações locais;

- Os empresários receberam a pior avaliação da população, que devem reduzir a poluição industrial;

- Quanto às principais preocupações da população, foram apontadas desemprego, saúde, educação, segurança e moradia, e quanto à questāo ambiental, nas classes com renda e educação mais alta, ocupa o $7^{\circ}$ lugar, e nas de menor renda e escolaridade, cai para 110; e

- $95 \%$ dos brasileiros acreditam que a educação ambiental é a chave para a mudança, sendo favoráveis à obrigatoriedade do tema nas escolas.

Apesar de o meio ambiente não aparecer entre as principais preocupações dos brasileiros, como desemprego, saúde, educação, segurança e moradia, ocupa o $7^{\circ}$ lugar nas preocupações das pessoas com maior nivel educacional e renda, e nas pessoas com menor escolaridade e renda, esta posição cai para $11^{\circ}$ lugar. 
A pesquisa ainda mostra que o Governo Federal, seguido da conscientização de cada um de nós e das Prefeituras, e o Governo Estadual são apontados como os principais responsáveis pela solução de problemas ambientais. Tanto em 92 quanto em 97 , os empresários foram os vilões do meio ambiente. Eles constituem o grupo que recebeu a pior avaliaçāo da populaçāo.

Crespo (1997) ainda relata que para reduzir a poluiçāo de origem industrial, mais da metade dos brasileiros acredita que o Governo deve aumentar a fiscalização e que o Congresso deve votar leis mais rigorosas;. $35 \%$ são a favor de incentivos às indústrias, tais como descontos nos impostos, para que invistam em preservação do Meio Ambiente.

No Estado de São Paulo, o ritmo acelerado do crescimento industrial está associado a um estágio crítico que foi atingido no desenvolvimento econômico do Estado, que gerava à população grandes oportunidades de trabalho, porém proporcionava a essa mesma população aumentos expressivos nos niveis de poluição ambiental.

A falta de planejamento causou o processo de urbanização na cidade de São Paulo de forma desequilibrada. Essa desordem junto às politicas industriais e de desenvolvimento urbano baseadas em cenários de crescimento contínuo, cujo enfoque é apenas econômico, tem levado a questão da poluição do ar na Região metropolitana de São Paulo a atingir niveis críticos. 
O processo de crescimento nos grandes centros urbanos tem trazido a deterioração da qualidade do ar, evidenciando o risco iminente à saúde, e desde 0 início da década de 80 , constatou-se que os veículos automotores representavam a maior fonte de emissão de poluentes atmosféricos.

\section{2. estado de são paulo - QuAlidade do AR, POlUição ATMOSFÉRICA E REFLEXOS NA SAÚDE}

O Estado de São Paulo, hoje, apresenta sérios problemas, dentre os quais podemos citar os de eliminação de residuos sólidos (lixo), consumo de água, problemas de invasões de loteamentos em áreas de mananciais e o de poluição atmosférica, sendo que os padrōes de qualidade do ar considerados como satisfatórios freqüentemente são ultrapassados, repercutindo e impactando diretamente no meio ambiente.

Conforme descrito no "Documento de Discussão Pública Por um Transporte Sustentável" (CETESB, 1997), "considera-se poluente qualquer substância presente no ar e que pela sua concentração possa torná-lo impróprio, nocivo ou ofensivo à saúde, inconveniente ao bem-estar público, danoso aos materiais, à fauna e à flora ou prejudicial à segurança, ao uso e gozo da propriedade e às atividades normais da comunidade." 
Resumidos na tabela a seguir, os principais poluentes atmosféricos de origem veicular e seus efeitos na saúde.

TABELA 4: Principais poluentes, fontes e impactos à saúde e meio ambiente

\begin{tabular}{|c|c|c|}
\hline POLUENTES & FONTES & $\begin{array}{l}\text { IMPACTOS À SAÚDE E AO } \\
\text { MEIO AMBIENTE }\end{array}$ \\
\hline Dióxido de enxofre (SO2) & $\begin{array}{l}\text { Queima de combustíveis fósseis } \\
\text { (carråo, petróleo) }\end{array}$ & $\begin{array}{l}\text { Agrava as doenças respiratórias. } \\
\text { Aumenta a possibilidade de } \\
\text { doenças cardiovasculares. } \\
\text { Contribui para a acidificaçáo de } \\
\text { corpos d'água e do solo. }\end{array}$ \\
\hline $\begin{array}{l}\text { Oxidos Nitrogenados } \\
\text { (Nox,NO,NO2) }\end{array}$ & $\begin{array}{l}\text { Queima de combustiveis fósseis } \\
\text { (carvão, petróleo) }\end{array}$ & 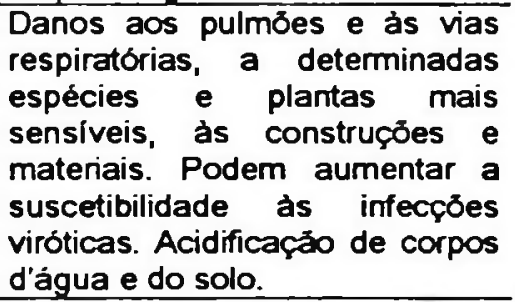 \\
\hline Monóxido de Carbono (CO) & $\begin{array}{l}\text { Veículos motorizados; } \\
\text { Processos de combustäo } \\
\text { industrial; } \\
\text { Queima de resíduos }\end{array}$ & $\begin{array}{l}\text { Debilita a capacidade sangūínea } \\
\text { de transportar o oxigênio para o } \\
\text { pulmåo; afeta os sistemas } \\
\text { cardiovascular, nervoso } r \\
\text { pulmonar. Contribui para a } \\
\text { formaça do ozônio na } \\
\text { atmosfera. }\end{array}$ \\
\hline $\begin{array}{l}\text { Compostos Orgânicos } \\
\text { (hidrocarbonetos } \\
\text { aldeidos) }\end{array}$ & $\begin{array}{l}\text { Veículos motorizados } \\
\text { (principalmente a álcool); } \\
\text { Indústrias }\end{array}$ & $\begin{array}{l}\text { Alguns compostos causam } \\
\text { mutaçós e cảncer. } \\
\text { Contribuem para a formaçăo do } \\
\text { ozónio. }\end{array}$ \\
\hline $\begin{array}{l}\text { Ozônio - nocivo quando se } \\
\text { concentra na superficie da } \\
\text { Terra. Mas quando se concentra } \\
\text { a cerca de } 20 \mathrm{Km} \text { da superficie, } \\
\text { protege-a contra os raios } \\
\text { ultravioletas. }\end{array}$ & \begin{tabular}{|l} 
E um poluente secundário, \\
resultante da reação química \\
entre. NOx e compostos \\
orgânicos na presença de luz \\
solar.
\end{tabular} & $\begin{array}{l}\text { Irritaçáa dos olhos; congestão } \\
\text { nasal, reduçāo das funçōes do } \\
\text { pulmáo; diminuiçāo da } \\
\text { resisténcia à infecçóes; } \\
\text { envelhecimento precoce. É o } \\
\text { principal componente da névoa } \\
\text { densa. } \\
\text { Danifica a vegetaçăo. }\end{array}$ \\
\hline Material Particulado & $\begin{array}{ll}\text { Queima incompleta de } \\
\text { combustiveis e de seus aditivos } \\
\text { no processo industrial; } \\
\text { Veiculos (principalmente a } \\
\text { diesel); } \\
\text { Poeira do solo }\end{array}$ & 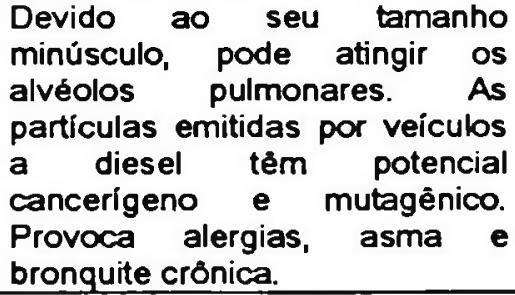 \\
\hline
\end{tabular}

Fonte: Adaptado de JACOBI, Pedro (coord.), Poluiçāo do ar em Sāo Paulo e resposta da ação pública. São Paulo, CEDEC/SEI - Centro de Estudos de Cultura Contemporânea/Stockholm Environment Institute. 1997. Cad. Cedec n60. 78P. p. 15 
No combate à poluição atmosférica, a CETESB desenvolve um conjunto de medidas que podem ser resumidas como:

- CAÇA-FUMAÇA - Combate à poluição excessiva de fumaça preta gerada por veículos a diesel, através de fiscalização de rua.

- PROCONVE - Programa de Controle da Poluição do Ar por Veículos Automotores - desenvolveu a base técnica da resolução 18/86 do CONAMA - Conselho Nacional do Meio Ambiente que fixa limites de poluição provocada por veículos novos.

- QUALIDADE DOS COMBUSTíveIS - Entendimento com setor energético, especialmente com a PETROBRÁS, para melhorar a qualidade dos combustiveis.

- MONITORAMENTO DA QUALIDADE DO AR - Além de várias atividades de controle, existem redes de monitoramento de qualidade do ar da Grande São Paulo e do Interior do Estado, que verificam o grau de exposição da população a agentes agressivos `a saúde humana e ao meio ambiente.

- OPERAÇÃO INVERNO - Ações de controle da poluição do ar na região metropolitana de São Paulo e de Cubatão, de caráter preventivo, para reduzir os niveis de poluição do ar, evitando a ocorrência de episódios críticos, e enfatizar a fiscalização de fontes de poluição; industrial, veículos automotores, fiscalizaçāo da fumaça, campanhas para regulagem dos motores dos veículos e Operação Rodizio.

- POLUIÇÃO INDUSTRIAL - Programas de controle implantados pela CETESB em indústrias para redução de poluentes. 
- I/M - Programa de Inspeção e Manutenção de Veículos em Uso desenvolveu a base técnica para Resolução7/93 do CONAMA, para controlar os veículos com motores desregulados e com emissão excessiva de poluentes.

O relatório CETESB sobre a Operação Rodizio 1998 (CETESB, 1999) diz que "A Região Metropolitana de São Paulo (RMSP), a maior da América do Sul, tem população aproximada de 16 milhões de habitantes e sua frota de veículos automotores, com cerca de 5 milhões de veículos licenciados, representa $25 \%$ da frota total do País, "verificando que a ocupação da frota é baixa com uma média de 1,5 passageiro/veículos, provocada pela carência de transporte público e uma tendência acentuada pelo transporte individual.

A Região Metropolitana de São Paulo (RMSP) tem sofrido episódios agudos de poluição do ar, principalmente no periodo de inverno, quando ocorre a inversão térmica dificultando a dispersão de poluentes, provocando um aumento das concentraçōes na atmosfera e caracterizando um episódio crítico. Pois conforme os niveis atingidos, os poluentes provocam efeitos nocivos à saúde da população, segundo o relatório da CETESB sobre os Efeitos da Operação Rodizio/98 na qualidade do ar na regiāo metropolitana de São Paulo (CETESB, 1998), provocando irritação nos olhos, agravando problemas de saúde da população, que é portadora ou suscetivel a problemas e doenças do aparelho respiratório e cardiovascular, principalmente crianças e idosos. 
Segundo Jacobi et al. (1997),. estudos da Universidade de São Paulo demonstram que a poluição do ar é responsável pelo aumento de $12 \%$ da mortalidade entre a população de crianças com menos de 5 anos e idosos, em conseqüência de doenças respiratórias relacionadas aos agravos da poluição.

Conforme estabelecidas na Constituição Estadual, a preservação e melhoria do meio ambiente e a manutenção da saúde pública são responsabilidade do Estado. A Secretaria do Meio Ambiente, com participação da sociedade, desenvolveu a Operação Rodizio que inicialmente surgiu como uma ação voluntária e de treinamento, durante uma semana em 1995. E a partir de 1996, transformou-se em lei.

Inicialmente, pretendia-se retirar $50 \%$ da frota, proibindo de circular os veiculos divididos em placas ímpares e pares, em todos os dias úteis da semana e com aplicação de multa. No ano de 1995, a imprensa já nos primeiros meses do ano noticiava a intenção da SMA de implantar essa ação durante todos os dias de inverno.

Porém, os técnicos da SMAVCETESB, órgãos responsáveis pela execução da Operação, ao analisarem a sua operacionalização, como fiscalização, estrutura de transporte público, infra-estrutura interna, etc, optaram pela implantação do modelo adotado no Chile que restringe $20 \%$ da circulação diária, mas para vincular a restrição à multa, seria necessário 
enviar e aprovar um projeto de lei na Assembléia Legislativa do Estado, e não houve tempo hábil para elaborar um projeto.

Optou-se por implantar um rodizio voluntário durante uma semana abrangendo toda a RMSP e com fiscalizaçāo restrita à área central, visando provocar na sociedade uma reflexāo sobre a necessidade de se equacionar urgentemente uma série de problemas estruturais, como falta de um sistema de transporte público adequado, congestionamento crônico, política de uso de combustíveis "limpos", e outros problemas que resultam em poluição. Os objetivos básicos da Operação foram dois, conforme descritos no relatório da Operação Rodízio Relatório de avaliaçāo (CETESB, 1995):

1. "Realizar um exercício de defesa civil envolvendo a populaçāo da Regiāo Metropolitana de São Paulo, visto que a legislação ambiental do Estado prevê que em casos de ocorrência de episódios críticos de poluição do ar, quando houver a decretação do estado de Alerta ou Emergência, é necessário restringir a circulaçăo de veículos na intensidade e tempo necessários até que os niveis de poluição retornem aos padrões aceitáveis;

2. Testar a resposta da sociedade à prática da restrição da circulação de veículos, que possa ser implementada anualmente, durante o período de inverno, quando as condiçōes de dispersão de poluentes são desfavoráveis." 
Assim, inserida na campanha "Ajude São Paulo a sair do sufocon que estimulou a utilização do transporte coletivo e da carona através da distribuição de vários materiais impressos, a Operação Rodizio foi realizada de forma voluntária, visando avaliar o grau de adesão da população e colher subsidios para estruturar o sistema de rodízio anual, durante o inverno, e subsidiar a elaboração de um anteprojeto para ser encaminhado à Assembléia Legislativa revendo, inclusive, a aplicaçāo de multa.

A Operaçāo Rodizio é uma medida drástica de intervenção urbana que tem experiência em outros países como França/Paris, Chile/Santiago do Chile, Malásia/Singapura, Itália/Milão, México/Cidade do México, Grécia/Atenas, onde a relação entre poluição e doenças respiratórias foi utilizada. Basicamente a operação consiste na restrição da circulação de veículos em determinados meses do ano, dias da semana e horários, através de uma escala de rodizio.

Na visão de Jacobi et al. (1997), a SMA investiu maciçamente na questão da saúde, visando reforçar a necessidade desta medida, sendo chamada de "medida de defesa civil pela saúde pública", visando convencer a população de que o rodizio embora desagradável, era extremamente necessário diante do significativo aumento de doenças respiratórias durante o inverno, o que foi um argumento visto com simpatia por uma parcela da populaçāo sensível aos problemas sociais. 
Podemos observar que nos objetivos relatados, na natureza em que a Operação foi criada e na missão da SMAVCETESB em implantar a Agenda 21 no Estado, está claro o envolvimento de uma mudança de comportamento da população quanto à utilização do rodizio como proteção ambiental.

\subsection{O SISTEMA ESTADUAL DO MEIO AMBIENTE - SISEMA}

\subsubsection{ESTRUTURA ADMINISTRATIVA}

A Secretaria do Meio Ambiente foi criada pelo Decreto $n^{\circ}$ 24.923 em 24 de março de 1986 e regulamentada pelo Decreto 30.555 de 3 de outubro de 1989, conforme relatado no Perfil Ambiental e Estratégias (SÃO PAULO, 1992), com o objetivo de promover a preservaçāo, a melhoria e a recuperação da qualidade ambiental, coordenar e integrar as atividades ligadas à defesa do meio ambiente, promover a elaboração e o aperfeiçoamento das normas de proteção ao meio ambiente, incentivar o desenvolvimento de pesquisas e processos tecnológicos destinados a reduzir a degradação da qualidade ambiental e estimular atividades educativas e a participação da comunidade no processo de preservação do meio ambiente. 
Para a correção e a prevenção da degradação ambiental, a Secretaria conta com a integração de diferentes instrumentos, realizada através de processos de parcerias entre o Estado, as Prefeituras, as Organizaçōes Não Governamentais (ONG's), os Institutos de Pesquisa, as Entidades Educacionais e a Sociedade Civil em geral, visando convocar a população e os setores produtivos a realizar a tarefa de criar ou reconstruir uma qualidade de vida para todos.

Trabalhando com o conceito de que as questões ambientais devem permear todos os diferentes setores do Governo, estabelecendo uma nova relação com o setor produtivo e com a sociedade civil , tornando-os coresponsáveis pelas diretrizes, decisões e ações na área ambiental, num grande exercicio de cidadania. São Paulo é um dos poucos Estados a adotar os preceitos da Agenda 21.

Convém observar que a Secretaria de Estado do Meio Ambiente - SMA, visando criar uma reflexão sobre as questōes ambientais e contribuir para ampliar a consciência pública e formação profissional, possui um Programa Estadual de Educação Ambiental vinculado à Agenda 21, que teve presença marcante nas ações do rodizio nos diversos materiais de apoio e divulgação, em atividades nas escolas e em consulta popular realizada com alunos e professores.

Após sua criação, conforme dados do relatório Parcerias para uma melhor qualidade de vida (SMA, 1997), a Secretaria incorporou o 
Conselho Estadual do Meio Ambiente (Consema) e outros órgãos já existentes em outras secretarias. Estes órgãos reunidos formam o Sistema Estadual do Meio Ambiente (SISEMA). Em seu quadro de funcionários, conta com cerca de 5.000 pessoas, sendo integrada por quatro coordenadorias:

- CPRN - Licenciamento Ambiental e Proteção de Recursos Naturais; integrado por:

- DAIA - Departamento de Avaliação de Impacto Ambiental;

- DUSM - Departamento de Uso do Solo Metropolitano e

- DEPRN - Departamento Estadual de Proteção de Recursos Naturais.

- CPLA - Planejamento Ambiental

- CEAM - Educação Ambiental

- CINP - Informações Técnicas, Documentação e Pesquisa Ambiental que coordena três institutos de pesquisa:

- IBT - Instituto de Botânica;

- IF - Instituto Florestal e

- IG - Instituto Geológico.

Ainda em sua estrutura, estão vinculados:

- CONSEMA - Conselho Estadual do Meio Ambiente;

- CETESB - Companhia de Tecnologia de Saneamento Ambiental Agência Ambiental do Estado de São Paulo e 
- Fundação para a Conservação e a Produção Florestal do Estado de São Paulo.

Para atender as duas administrações, direta e indireta, a Coordenadoria de Comunicação (CCO) está ligada diretamente à Secretaria do Meio Ambiente.

Essa estrutura visa administrar a realidade ambiental do Estado de São Paulo, sendo que para cada questão ambiental, a SMA busca mecanismos de interação com a realidade específica.

Esta estrutura pode ser melhor visualizada na figura a seguir.

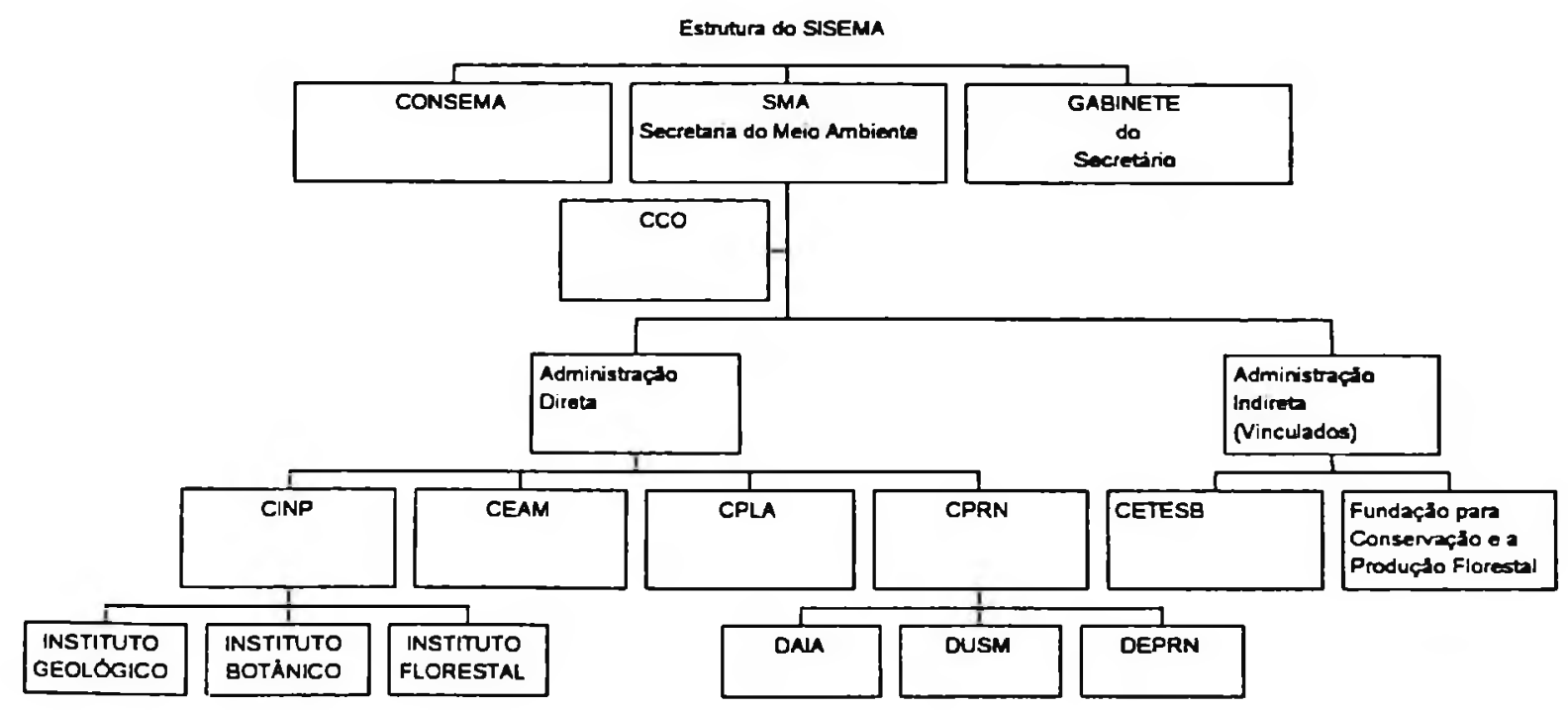

FIGURA 12: Estrutura do SISEMA

Fonte: Adaptada da SMA - Parcerias para uma melhor ..., (1997,.p.6). 


\subsubsection{A CETESB}

Destaca-se nessa estrutura a CETESB, que é a agência paulista responsável pelo desenvolvimento de açōes voltadas para promoção, proteção e recuperação da qualidade do ar, águas e solo, e voltadas para controle, licenciamento, fiscalização e monitoramento das atividades potencialmente poluidoras.

O Governo do Estado de Sāo Paulo é seu principal acionista, mas a companhia está organizada nos moldes de empresa privada, gozando de flexibilidade e autonomia administrativa própria deste tipo de organização, ou seja, seus empregados não sāo considerados servidores públicos e estão sujeitos ao regime das leis trabalhistas que regem os funcionários das empresas privadas.

Os recursos financeiros são provenientes de verbas orçamentárias do Tesouro do Estado e verbas obtidas com prestação de serviços (recursos próprios).

Esta estrutura tem como área de atuação basicamente o Estado de São Paulo, o mais desenvolvido do Pais, mas também o que apresenta os mais graves problemas ambientais. $O$ polo industrial de Cubatão, chamado "Vale da Morte" Brunacci, (1994), é um exemplo tipico. 
Atualmente a CETESB é um centro difusor da tecnologia de saneamento ambiental com prestígio internacional, incluída como um dos centros de referência da ONU - Organização das Nações Unidas para questōes ambientais. Tem um quadro de técnicos de nivel médio e superior, altamente especializados, atuando efetivamente em todas as áreas de preservação e recuperação ambiental, contribuindo para a melhoria da qualidade de vida dos habitantes do Estado de São Paulo.

Dentro deste contexto, além da "Operação Rodízio", a empresa desenvolve programas de tecnologia e controle da poluição do ar, água e solo, treinamento e transferência de tecnologia, planejamento ambiental, assistência aos municipios e cooperação institucional com outras entidades, seja no plano nacional ou internacional.

A gama de serviços prestados é bastante ampla, abrangendo, por exemplo, análises físico-químicas e microbiológicas, assistência técnica, licenciamento e reclamações, uso do solo (planejamento), publicações, acidentes e riscos ambientais, fiscalização, oceanografia e hidrologia, treinamento de mão de obra, etc.

Entre seus consumidores, além da população como um todo, estão órgãos governamentais, companhias de saneamento, firmas de engenharia e consultoria, prefeituras municipais, centros de tecnologia e pesquisa, indústrias, empresas de economia mista e entidades de classe, em todo o território nacional e no exterior. 
A CETESB, possui cinco diretorias em sua estrutura organizacional, e seu nível hierárquico está dividido em quatro escalões: o Diretor, ○ Gerente de Departamento, ○ Gerente de Divisão e o Gerente de Setor. Composta por aproximadamente 166 unidades, distribuidas entre 5 Diretorias, 27 Departamentos, 47 Divisões e 87 Setores, incluindo unidades regionais no Estado de São Paulo.

\subsection{ASPECTOS JURÍDICOS E CONTESTAÇÕES}

As ações de restrição à circulação de veículos automotores, caracterizadas como Operação Rodizio, foram previstas nos seguintes textos:

- 1995 - Decreto Estadual n40.280, de 18 de agosto de 1995;

- 1996 - Decreto Estadual $n^{\circ} 41.049$, de 26 de julho de 1996, que regulamentou a Lei $n^{\circ} 9.358$ de 13 de junho de 1996, que autorizou o Poder Executivo a implantar o Programa de Restrição à Circulação de Veículos Automotores na Regiāo Metropolitana de Sāo Paulo.

Em cumprimento ao artigo 10 da Lei $n^{\circ}$. 9.690, a SMAVETESB realizou uma consulta popular nas escolas, com alunos de $5^{\mathrm{a}}$ a $8^{\mathrm{a}}$ séries do primeiro grau e da $1^{*}$ a $3^{*}$ séries do segundo grau, incluindo os professores. 
- 1997 e 1998 - Lei $n^{\circ}$ 9.690, de 2 de junho de 1997, que autorizou a implantação do Programa de restrição à Circulação de Veículos Automotores na Região Metropolitana da Grande São Paulo nos anos de 1997 e 1998. Sendo regulamentada pelo Decreto $n^{\circ} 41.858$ de 12 de junho de 1997 e posteriormente alterada pelo Decreto $n^{\circ} 43.029$ de 9 de abril de 1998.

Para aprovação e sustentação do projeto de lei, visando legitimar a proposta, foram feitas referências a estudos acadêmicos desenvolvidos no Laboratório de Poluição Atmosférica da Faculdade de Medicina da USP sobre os efeitos da poluição na saúde e pesquisa desenvolvida pelo Cedec (Jacobi, 1994) sobre percepção de problemas ambientais urbanos, nos quais as fontes de poluição de veículos são um dos itens mais destacados. Referências também ao Decreto $8.468 / 76$ que prevê - Plano de Emergência para Episódios Críticos de Poluição do Ar.

Apesar dos argumentos sobre os altos indices de poluição e seus reflexos na saúde pública, a aprovação do projeto enfrentou uma série de dificuldades e críticas na Assembléia Legislativa, da Comissão de Meio Ambiente e Educação, quanto a sua legalidade e eficácia alegando que o rodízio deveria ter um caráter mais educativo que punitivo, referindo-se à polêmica questão da multa e evidenciando a existência do transporte público de baixa qualidade e insuficiente. 
O projeto foi aprovado recebendo várias emendas, como redução no valor proposto inicialmente no projeto e a criação de um fundo, determinando que os recursos gerados pela arrecadação das multas deveriam ser destinados aos programas de saneamento ambiental. A Operação deveria ainda ter um custo zero para o Estado, cabendo à SMA efetivar contratos publicitários.

A SMA compôs um comitê interdisciplinar chamado de "Comitê Consultivo de Controle da Poluição do Sistema de Transporte do Estado de São Paulo, visando articular os setores envolvidos e formular propostas para reverter o quadro de riscos que comprometem a qualidade de vida da população e envolvendo vários setores do Governo e da sociedade civil, representada pelo CEDEC e pelo Greenpeace.

O comitê fez parte do Programa Operativo de Controle da Poluição do Sistema de Transporte do Estado de São Paulo, criado por Decreto em 6 de março de 1996, apresentando um projeto de açōes integradas, em âmbito federal, estadual e municipal, de transporte, energia, uso e ocupação do solo e controle da poluição, com reuniōes semanais, integrando as seguintes entidades, conforme Jacobi (1997) relata: MMA, MICT, Ibama, INMETRO, ST, STM, SEE, SES, SCTDE, SE, SSP, SMA, SEF, Cetesb, Metrô, DER, DERSA, CEDEC, Cedec, PMSP, SVMA, SMT, CET, EMTU, CPTM, FEPASA, USP, ANTP, IE e Greenpeace. 
É importante lembrar que logo no início da implantação do rodizio, houve um embate entre Prefeitura e Estado, em função do convênio firmado para o Programa do I/M, sendo apontada irregularidade no processo de licitação realizado pela Prefeitura para escolha das empresas que executariam o Programa.

A Prefeitura nāo apoiou o rodizio, e paralelamente surgiram questionamentos técnicos sobre a validade ou nāo e debates questionando a constitucionalidade do rodízio, com alegaçōes de que o rodizio impede o direito de ir e vir e fere o direito de propriedade, pois o pagamento do IPVA garante 0 direito de circular livremente com o carro, porém o Tribunal de Justiça do Estado de São Paulo julgou o recurso encaminhado, negando as solicitações sob alegação de que o direito coletivo não se sobrepõe ao individual.

Entidades, como a OAB, alegando que o Estado estaria invadindo competência federal supostamente ao legislar sobre matéria de trânsito, e outras associaçōes de profissionais também se posicionaram brigando na justiça pelo direito de circular sem ser multadas, como médicos, advogados criminalistas, locadoras de automóveis. Algumas empresas preferiram pagar multa a deixar de trabalhar, gerando várias açōes e mandados de segurança contra a Operação Rodízio.

A SMA enfrentou ainda uma resistência cultural dos técnicos que tiveram de ir para as ruas e uma oposição do Conselho de 
Representantes dos Funcionários (CRF) da CETESB que apontou como negativa a priorização da Operação Rodizio, pois paralisou outras atividades igualmente importantes para a qualidade ambiental no Estado de São Paulo, e também se deparou com uma greve no primeiro dia do rodizio obrigatório.

Embora tivesse recebido diversos apoios e parcerias com a iniciativa privada, outros Órgãos do Estado e ONG's ficaram divididos. A maioria levantou críticas a respeito da falta de transporte público melhor e mais adequado, estimulando a troca de transporte dos usuários de automóveis e questionando a não inclusão dos caminhōes. Jacobi et al. (1997) relatam que "Segundo Feldmann, as ONGs não têm tradição de relacionamento com o Governo."

Porém, algumas ONG's, como sos Mata Atlàntica, em apoio ao projeto "Respira São Paulo", visando criar uma campanha de mobilizaçāo para melhoria e recuperaçāo da qualidade do ar da RMSP e promover um canal de participação, vendeu kits contendo um lençol que ficava exposto por um mês em diversos locais, como prédios, árvores, etc., visando monitorar a qualidade do ar através da cor do tecido, indicando o indice de poluição, e um cartão que era devolvido para a entidade. As ações desenvolvidas foram baseadas em outras entidades ambientalistas internacionais.

A imprensa também ficou dividida, embora alguns jornais tivessem se posicionado abertamente contra a medida, ressalta-se que os 
meios de comunicação são formadores de opinião e que indiretamente podem criar uma indisposiçāo da população contra o Rodizio.

\subsection{O RODIZIO DA PREFEITURA}

O Rodizio da Prefeitura foi desenvolvido como medida prática e como alternativa de otimização da utilização do espaço viário disponivel no município de São Paulo, coordenado pela Secretaria Municipal de Transporte e de seus órgãos gerenciadores de trânsito - DSV e CET.

Conforme Relatório de Avaliação sobre a Operação Horário de Pico (SÃO PAULO, 1998), chamada de Rodízio Municipal, foi instituída pela Lei $n^{\circ} 12.490$, devidamente regulamentada pelo Decreto $n^{\circ} 37.085$ publicado no Diário Oficial do Município de 04 de outubro de 1997.

A Operação Horário de Pico, conforme apontada no referido relatório, tem aprovação de $73 \%$ da população, apresentando fluidez no trânsito, no chamado Centro Expandido, e com redução da lentidão no pico da manhã, igual a $37 \%$, e no pico da tarde, $26 \%$.

O Rodízio Municipal tem o objetivo de melhorar o trânsito e consiste em um programa de restrição de circulação de veículos, 
exclusivamente em horários e locais mais críticos, por meio de um escalonamento na utilização dos veículos. Em sua divulgação, considera a conscientização da população, a alteração de horários de circulação, a operação de veículos de carga, as informaçōes à população sobre os melhores horários para utilização do sistema viário, entre outras diretrizes.

Portanto, o rodízio municipal não será abordado neste estudo pois é voltado para melhorar o trânsito, sendo diferente do rodizio estadual que objetiva melhorar a qualidade do ar e é voltado para a saúde pública, foco desta dissertação.

\subsection{IMPLANTAÇĀO E ESTRUTURA DA OPERAÇÃO RODIZIO}

Para operacionalizar o Programa de Restrição à Circulação de Veículos, atingir $\circ$ objetivo de reduzir as emissōes de poluentes atmosféricos e garantir o cumprimento da lei, um conjunto de ações deram suporte ao rodizio fazendo parte da campanha "Respira São Paulo".

Foi estabelecida uma coordenação geral, responsável por todos os procedimentos operacionais, e formado um grupo de trabalho composto por vários profissionais da CETESB e SMA. O grupo era responsável pelas diversas etapas e tarefas ligadas ao trabalho, como 
fiscalização de rotina, mutirões de fiscalização, triagem e conferência de multas, recepção e análise de recursos, informação da população através do telefone e de um balcão de atendimento, panfletagem e contagem de carros, contrataçāo de pessoal temporário e demais atividades administrativas. A estrutura da Operação Rodízio pode ser melhor visualizada na figura adaptada do relatório da Operação Rodízio 1998.

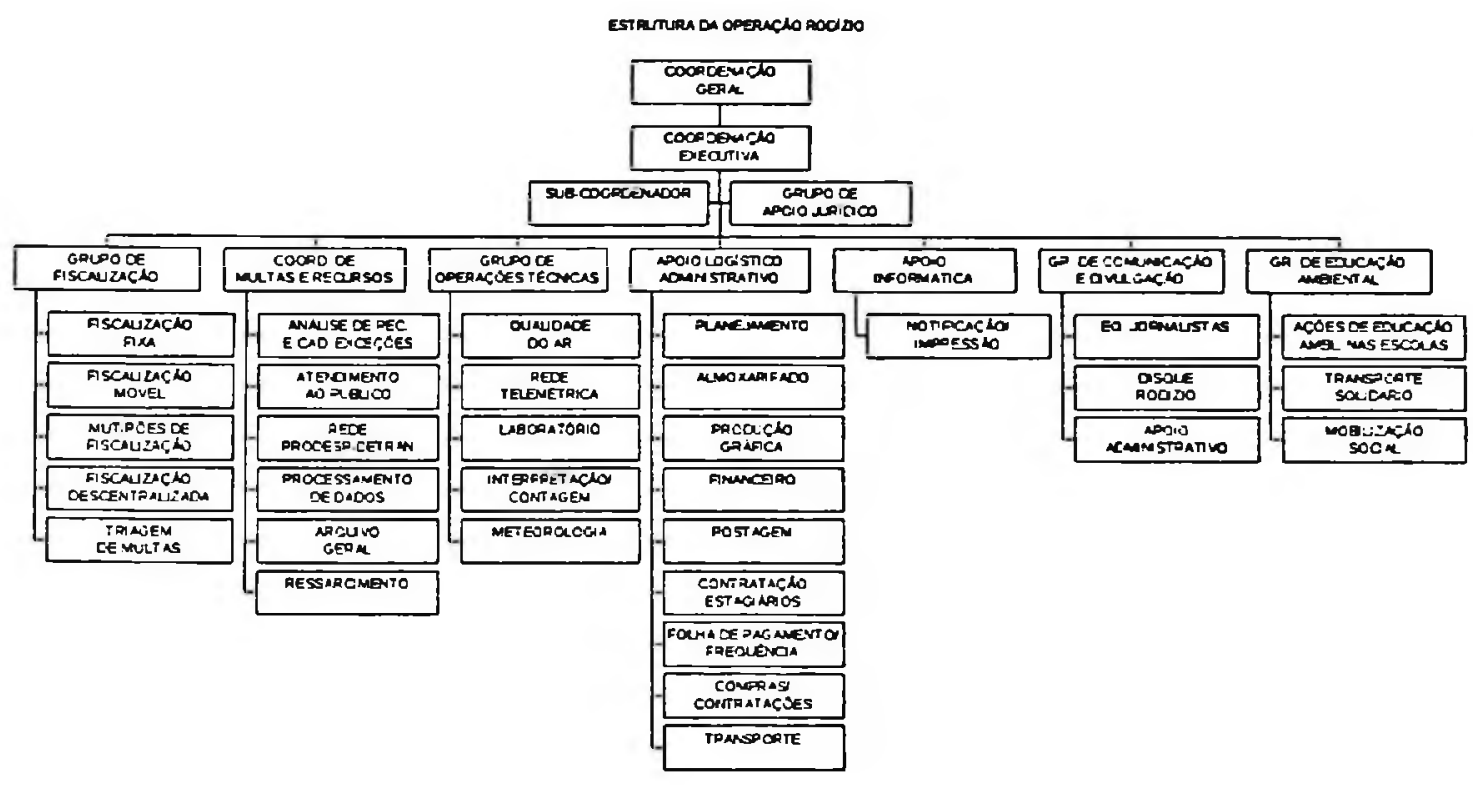

FIGURA 13: Estrutura da operação rodizio

Fonte: $\quad$ CETESB - Relatório, Operação Rodízio 1998 (1999)

Na campanha "Respira São Paulo", visando promover a carona, foi desenvolvido um software para escolas e empresas chamado Transporte Solidário. Foi incluida ainda a estratégia de telemarketing com mensagens gravadas por personalidades do mundo artístico como forma de sensibilização da população e ação de divulgação da Operação Rodízio junto às escolas estaduais, municipais e particulares, com kits e material informativo impresso. 


\subsection{A CAMPANHA 1995 a 1998}

Conhecido como "Operação Rodizio", o Programa de Restrição à Circulação de Veículos Automotores na Região Metropolitana foi implantado tendo como principal objetivo a melhoria da qualidade do ar, e como objetivos secundários educar o cidadão conscientizando-o sobre os efeitos da poluição na saúde humana, identificar as principais fontes emissoras de poluentes e provocar mudanças de hábitos que se estendem além do periodo de vigência do Rodízio, conforme apontado na Pesquisa do Perfil do Infrator, (CETESB, 1997).

A campanha da SMAVETESB iniciou em 1995, sendo desenvolvida para obter a adesão voluntária da população, motivando as pessoas a deixar seus veículos em casa uma vez por semana, a adotar outras alternativas de transporte, como ônibus e outros coletivos, táxis, carona (solidário) e/ou a mudar seus horários de deslocamento.

O rodízio foi implantado de 28 de agosto a $1^{\bullet}$ de setembro, no horário das $7 \mathrm{~h} 30$ às $17 \mathrm{~h} 30$, conforme final da placa, sendo excluidos, táxis, motocicletas, ônibus, caminhões e veículos de transporte de pereciveis, essenciais e de emergência, conforme Operação Rodizio Relatório de Avaliação (CETESB. 1995). 
A implantação do rodizio nos anos seguintes, após aprovação jurídica, ocorreu nos mesmos moldes da operação de 1995, com uma redução de $20 \%$ da frota diária e por um periodo mais longo, inclusive com alteração nos horários de vigẽncia, iniciando às $7 \mathrm{~h}$ e terminando às 20h. Posteriormente foi adotado o "rodízio do rodizio" que mudava os finais de placas de acordo com o dia da semana.

O Governo, após aprovação, decidiu restringir o programa atingindo 10 municípios da Região Metropolitana: São Paulo, Guarulhos, Osasco, Santo André, São Bernardo do Campo, São Caetano do Sul, Diadema, Mauá, Ferraz de Vasconcelos e Taboão da Serra. Os demais municipios pertencentes a RMSP com frotas pouco significativas não foram atingidos.

A partir de 1996, o rodizio passou a ser obrigatório, e a SMANCETESB, com base nos resultados da experiência anterior de 1995, estudou novas estratégias de divulgação e incorporou a multa como um poderoso instrumento coercitivo, definindo como metas:

- "Reduzir em até $30 \%$ as emissões de CO na região de abrangência da Operação;

- Prevenir a ocorréncia de episódios críticos de poluição do ar causados pelo $C O$ e reduzir as freqüentes ultrapassagens do padrão legal do referido poluente; 
- Conscientizar a população sobre a gravidade do problema da poluição em São Paulo;

- Educar o cidadão para a identificação das principais fontes emissoras de poluentes;

- Conscientizar o cidadão sobre os efeitos da poluição sobre a saúde humana, que se fazem sentir a curto e longo prazos;

- Provocar a discussão sobre os aspectos cruciais da cidade, ressaltando a importância do planejamento, uso do solo, energia, transporte, saúde e meio ambiente;

- Preparar a sociedade para eventuais casos de emergência;

- Melhorar o trânsito da cidade e, conseqüentemente, reduzir a poluição atmosférica e sonora;

- Provocar mudanças de hábito que se estendam para além do período de vigência do rodizio;

- Contribuir para a formulação de politicas públicas que tragam resultados da melhoria da qualidade do ar (Governo do Estado de São Paulo, 1997b.p.8)." Jacobi, et al. (1997)

Segundo Jacobi et al. (1997), com essas metas, ficou caracterizada a intenção da SMANCETESB de diminuir o volume de automóveis, independentemente das contribuições de cada fonte, gerando questionamentos sobre o tratamento indiscriminado com veículos a álcool, 
com catalisador ou injeção eletrônica, carros velhos que são mais poluentes, caminhões e ônibus.

Surgiram questionamentos quanto à validade do rodizio para os veículos leves, uma vez que a poluição gerada pelos veículos pesados (fumaça preta) era mais perceptivel aos olhos da população, e a redução do monóxido de carbono e gás incolor e inodoro, que era o alvo principal da Operaçāo Rodízio, não era percebida pela população.

Os técnicos da CETESB eram contrários à inclusão dos caminhōes, pois já havia a operação caça-fumaça e havia dúvidas quanto à constitucionalidade de uma dupla autuação.

A multa era considerada ambiental, no valor de $R \$ 100,00$ (cem reais) por dia de utilização irregular do veículo, e em caso de reincidência na infração, no mesmo período do ano, a multa ambiental tinha o seu valor dobrado, e cada vez que tivesse reincidência da reincidência, a multa tinha o seu valor acrescido do dobro do seu valor inicial, ou seja, R\$ 200,00 (duzentos reais).

Porém, havia pressão dos sindicatos das empresas transportadoras de carga, que firmaram acordo com a SMA assegurando que passariam a regular os motores dos caminhōes para nāo ser incluídos no rodizio, sendo que a SMACETESB intensificou a fiscalização da operação caça-fumaça. Quanto aos ônibus, não havia muitos 
questionamentos, por constituirem o principal meio de transporte coletivo da Regiāo Metropolitana de São Paulo.

No ano de 1997, a SMA cadastrou junto a entidades representativas, os motoristas deficientes físicos e instituiçōes, como APAE e a AACD, deixando-os fora do rodízio. Em 1996, os veículos que transportavam deficientes nāo foram isentos porque nāo havia um cadastro confiável, porém os médicos e outras categorias de profissionais foram incluidos no rodízio, e os veículos de outros municípios em trânsito poderiam ser multados.

A CEAM intensificou a distribuição de material didático e acrescentou novos materiais de apoio, atuando em parcerias com as escolas, através de um convênio firmado entre a Secretaria do Meio Ambiente e a Secretaria de Educação, visando divulgar o Rodízio e impulsionar a campanha nas escolas. Em pesquisas realizadas pela CEAM, identificou-se a necessidade de orientar os educadores quanto à utilização do material fornecido.

Em 1998, dando continuidade à operação, como as ações anteriores, a fiscalização em 1996 e 1997 foi intensificada, e foi criado o Grupo de Açōes de Apoio à Operaçāo Rodízio, com as atribuiçōes de cadastramento de veículos, análise de recursos, processamento de dados, atendimento ao público, aprimoramento de sistemas junto ao PRODESP, etc, centralizando ainda as açōes operacionais e administrativas que 
facilitam a logística envolvida, como movimentação de veículos, material destinado à operação, triagem de multas, controle de agentes de campo e outras atividades.

A SMA coordenou os trabalhos com o Comitê Consultivo de Controle da Poluição do Sistema de Transportes do Estado de Sāo Paulo, elaborando um projeto de lei (publicado no Diário Oficial do Estado de 14 de abril de 1998) "Por um Transporte Sustentável" em atendimento aos objetivos estabelecidos no Decreto Estadual 40.700, de 6 de março de 1996, enfatizando a variável ambiental nas políticas públicas estaduais, federais e municipais de planejamento urbano: trânsito, transporte público, controle da poluição do ar, sonora e saúde, adequação da matriz energética, visando reduzir a poluição veicular, conforme Relatório da Operaçāo Rodízio 1998, (CETESB, 1999).

\subsection{RECURSOS E DIVULGAÇĀO}

Dois meses antes da operação, foram feitos contatos para encontrar empresas que bancassem toda a campanha. Porém em funçāo do baixo retorno, foram feitos "pacotes" de patrocínio que englobavam várias ações, como o fornecimento de papel para confecção de material para distribuição, confecção de camisetas, faixas, adesivos impressão e outros. 
A falta de uma campanha institucional com recursos próprios ocasionou alguns imprevistos, e "a campanha só obteve certa unidade de linguagem por interferência da Coordenadoria de Comunicação do Palácio do Governo que conseguiu a adesão de uma agência de publicidade para desenvolver toda a proposta das peças utilizadas. A partir dai, os contatos realizados na busca de patrocínio foram feitos com base em necessidades concretas e com estimativas de custos definidos." Conforme relatório da Operação Rodízio de avaliação (CETESB, 1995).

O material impresso produzido foi elaborado e padronizado com a mensagem "Ajude a Tirar São Paulo do sufoco" e tinha as cores azul, branca e preta associadas ao rodízio, conseguindo de certa forma marcar a campanha.

Foram utilizados vários recursos para a divulgação da campanha, e na busca de apoio e parceiros, a assessoria do Palácio conseguiu garantir a veiculação de spots em rádios, exposição de outdoor e publicação gratuita de anúncios em jornais, e a SMAVCETESB ficou incumbida de negociar com outras instituiçōes, como:

- Secretaria de Estado da Educação

- Dersa

- Representantes da iniciativa privada - shopping centers, sindicato dos zeladores, postos de gasolina, locadoras de veiculos, hipermercados, SIMP e FIESP 
- Promoveu campanhas nas ruas com a participação de todos os funcionários da SMA

- Apoio da Defesa Civil e do Grupo de Escoteiros do Estado.

O material gráfico foi distribuído em datas e lugares selecionados visando atingir maior número de pessoas. E em alguns pontos, além de panfletagem, também eram promovidas outras atividades, como início ou final de passeios ciclísticos e coletivas de imprensa.

Havia também outros pontos e locais que receberam apoio para a distribuição de impressos, como vários shopping centers, DERSA, Metrô, Sindicato de Clubes do Estado de São Paulo, Sindicato de Bens Imóveis e Condomínios de São Paulo e escolas.

Na relação de parcerias obtidas, empresas relacionavam o rodizio com seus produtos e serviços em suas campanhas publicitárias, como uma contribuição para reforçar a participação da população na Operação, como o Banco Real e Arisco, através de filmes para a TV e cinema, o Pão de Açúcar Delivery e a Aia Motors, em outdoor que desestimulou o uso do carro e estimulou a carona.

Conforme apontado no relatório da Operação Rodizio, do Exercício à Cidadania (CETESB, 1996), o material distribuido foi bem aceito pela população, não sendo encontrados impressos jogados no chão e das 
imediações dos pontos de panfletagem, e produzido em quantidade adequada, sem sobra significativa que indicasse desperdicio.

De acordo com o relatório Operação Rodizio 1997 - Respira São Paulo (CETESB, 1997), na atividade de fiscalização, foi desenvolvida toda uma estrutura de logística para suprimento de material, escalas de trabalho, relatórios e informaçōes para grupo sobre atividades, treinamentos, formação de equipes e revezamento na fiscalização, supervisão das equipes, refeiçāo, transporte, etc. Em pontos fixos, havia coordenadores que também executavam a fiscalização móvel autuando em percursos e rotas previamente definidas.

Quanto à atividade de controle e fiscalizaçāo, foram realizadas reuniōes com diversos sindicatos e prefeituras, e foi intensificada a fiscalização de fumaça preta em veículos a diesel, sendo oferecidos treinamentos e vistorias, e firmados acordos com IBAMA, Polícia Rodoviária Federal, SETCESP, TRANSURB e SINDICAM e um protocolo com a CocaCola. Em 1996, iniciaram-se os mutirões de "caça-fumaça", sendo que em 1997, a operação foi ampliada para todas as regiōes do Estado.

Na divulgação da Operação Rodizio, foram desenvolvidos diversos materiais, como publicações, panfletos, cartazes, fitas de vídeo, (houve uma produção feita pela própria SMA) e veiculados graciosamente na televisão, e um outro video patrocinado e apresentado nos cinemas da capital. 
Como recursos de comunicação utilizados na Operação Rodízio, foram também aproveitados fitas cassetes, blocos de fiscalizaçāo, revistas, jornais, questionários de pesquisa, adesivos para carro e calendários, balōes, faixas de pano e de plástico, camisetas, bonés, moletons, coletes de fiscalização, outdoors, anúncios de rádio, painéis eletrônicos, tickets (vale-refeição), telemarketing, Disque Rodizio, produtos de informática (software, CD-rom, Internet, homepage, seminários).

Ainda como recursos de divulgação, o relatório Operação Rodízio 1995 do Exercicio à Cidadania. (CETESB, 1996) aponta que foi realizada uma série de eventos, como debates, seminários e encontros em 1995 e em 1996, quando se discutiu desde experiências de outros países no controle da poluição do ar até propostas de transporte público, reescalonamento de horários e outros temas, com destaque à palestra proferida pelo Prof. Paulo Hilário Saldiva, da Faculdade de Medicina da Universidade de São Paulo, visando enfatizar a questão da saúde com o tema Poluição Urbana e Saúde, que foi divulgada pela mídia.

Foi implantado ainda o Disque Rodízio, operado por funcionários da CETESB que prestavam informaçōes e recebiam queixas e sugestōes, e instalada uma sala destinada à imprensa com objetivo de realizar entrevistas coletivas para divulgar e informar o boletim de qualidade do ar, tendo duas edições diárias no periodo do Rodízio. 
O relatório aponta que para a atividade de panfletagem, contagem de placas e adesão da campanha, foram feitos treinamentos para capacitar os funcionários da SMANCETESB e equipe da Defesa Civil para o contato direto com a população, em três seminários abordando possiveis questōes levantadas pelo público, procedimentos a ser adotados, objetivos da campanha, distribuição de material impresso e como tratar as pessoas.

A campanha, conforme Jacobi et al.(1997), contou também com um telemarketing com mensagens gravadas por artistas famosos e personalidades dos meios empresarial, político, artistico e esportivo para sensibilizar a população, o que atingiu aproximadamente 3 milhões de paulistanos. Esse serviço foi financiado por empresas privadas.

\subsection{OS MEIOS DE COMUNICAÇÃO}

Convém ressaltar que os meios de comunicação colaboraram para a difusão temática no processo de discussão desencadeado com a Operação Rodizio que teve um acompanhamento intenso nos diversos temas abordados, como transporte, saúde, matriz energética, etc. levando ao público leigo informaçōes para analisar a realidade ambiental de sua cidade. 
A SMA designou uma equipe de jornalistas ligada à Coordenação Geral do Programa que cuidava do atendimento e encaminhamento de solicitaçōes feitas pela mídia, como entrevistas individuais e informaçōes. O grupo elaborava um boletim informativo semanal chamado de "Rodízio de Notícias", que passou a ser o veículo oficial da Operação em 1996, sendo retomado nos anos seguintes (1997 e 1998).

O boletim informativo era enviado a todos os meios de comunicação da Grande São Paulo e utilizado para manter os funcionários do sistema ambiental informados sobre o desdobramento da Operação, sendo afixados nos murais dos órgãos integrantes do SISEMA. Todas as atividades do rodizio foram transmitidas ou distribuídas durante as entrevistas coletivas no periodo de preparação e desenvolvimento do programa, visando assegurar transparência e livre e pleno acesso às informaçōes.

A equipe também elaborava releases, boletins e balanços que diariamente eram transmitidos ou distribuidos em entrevistas coletivas nos períodos de preparo do rodízio. A divulgação era muito enfatizada. Foi ministrado, com exclusividade, um curso para a imprensa abordando temas como meteorologia, fenômeno da inversão térmica, indice e padrão de qualidade do ar, monóxido de carbono e outros poluentes. 
Conforme apontado no relatório da Operação Rodizio No Caminho Certo (CETESB, 1996), a discussão foi levada a todas as camadas sociais. Jornais, revistas e emissoras de rádio e televisão mantiveram o assunto em pauta, com publicação nos principais jornais e revistas da Região Metropolitana, interior e nas principais capitais do País, gerando várias matérias com destaques de manchete, temas de artigos ou editoriais.

A SMACETESB fez um levantamento da cobertura da mídia, o qual pode ser observado no quadro que segue, apresentando um panorama da cobertura nos diversos veículos e observando que não foram feitos levantamentos em estaçōes de rádio, por não possuirem um sistema de escuta e seleção de arquivos, embora os técnicos tenham participado de vários programas de entrevistas e debates.

\begin{tabular}{|l|c|c|c|}
\hline \multirow{2}{*}{ TIPO } & \multicolumn{3}{c|}{ QUANTIDADE } \\
\cline { 2 - 4 } & 1996 & 1997 & 1998 \\
\hline Publicação de matérias em jornais e revistas & 1.264 & 1.610 & 625 \\
Foram Machete ou ocuparam a página principal & 96 & 554 & 66 \\
\hline Artigos assinados ou editoriais & 69 & 146 & 33 \\
\hline Cartas de leitores & - & 226 & \\
\hline Pesquisas de opinião real p/veiculos de divulgação & 17 & 5 & 9 \\
\hline Veiculação em programas jornalísticos de TV & $14 \mathrm{~h}$ & $27 \mathrm{~h}$ & $6 \mathrm{~h}$ \\
\hline
\end{tabular}

QUADRO 4: Espaço ocupado na Mídia

Fonte: $\quad$ Relatórios da Operação Rodizio 1996 a 1998

Convém observar que segundo Jacobi et al.(1997), "..um ponto a ser destacado na investigação da imprensa acerca da opinião da população sobre o rodízio, tanto em 1995 como em 1996, foi a ênfase maior 
na escolha da população de classe média e alta, fatia que detêm a maior frota de veículos. A população que utiliza o transporte público, mais representativa em termos numéricos, foi praticamente ignorada nas pesquisas."

O autor faz uma observação alertando para os resultados apresentados nas pesquisas de opinião realizadas pelos próprios veículos, relatando que uma pesquisa de 1995 revelou que $68,9 \%$ das pessoas consultadas consideravam o rodízio um fracasso e que se a outra parcela da populaçāo tivesse sido ouvida, o resultado poderia ser diferente.

A SMAVETESB realizou com recursos próprios duas pesquisas, a de "Usuários de automóveis sobre as alternativas de transporte utilizadas durante a Operação Rodízio 1996 " e outra sobre o "Perfil do Infrator" em 1997. E uma terceira em parceria com CEDEC e CEAM/SMA nas escolas, objetivando "conhecer a opinião de pais de alunos sobre as conseqüências da Operação Rodizio no seu cotidiano de vida."

O tema Operação Rodízio causou polêmica quanto à restrição de utilização de veículos, dividindo diversos segmentos e a própria mídia, sendo que alguns veículos se posicionaram favoráveis, e outros contrários, gerando diversas discussões sobre os problemas da cidade e evidenciando outras questōes como transporte urbano. 
Os relatórios da Operação revelam que nas argumentaçōes dos jornais prevaleceu uma conotação negativa sobre as positivas, porém no decorrer do rodízio, houve um decréscimo dessa posição, "...evidenciando um comportamento que tendia ao descrédito da operação ou mesmo à tentativa de inviabilizá-la, uma vez que a maioria dos artigos publicados baseava-se em argumentações de natureza especulativa desprovidas de dados objetivos que pudessem fundamentar essas opiniões a partir de uma experiência anterior nos mesmos moldes." Operaçāo Rodízio 1996 - No Caminho Certo (CETESB, 1997)

Os artigos que se posicionaram como favorável ao rodizio enfatizavam a atenção sobre os resultados e uma preocupação de situar a operação dentro de uma perspectiva de melhoria da qualidade de vida e de combate à poluição.

O posicionamento contraditório da imprensa evidenciou que alguns jornais adotaram uma linha de defesa do Programa I/M em detrimento da Operação Rodízio, que de acordo com as suas análises “...não passava de capricho do secretário Feldmann, que estaria mais preocupado com sua imagem política do que com a melhoria da qualidade do ar." Jacobi et al. (1997)

Jacobi et al. (1997) alertam sobre essa postura dizendo que a superexposição de uma medida tão polêmica como essa, apesar de promover politicamente o secretário, o expõe a um enorme risco por ser uma 
medida à primeira vista antipática à população, e que a questão não é discutir a visibilidade política, mas sim a visibilidade e a eficácia de uma medida que visa melhorar a qualidade de vida da população.

Em uma análise feita da cobertura jornalística por Medina (1998), a autora ressalta o papel desempenhado pelos veículos de comunicação como sendo o "Quarto Poder", alegando que:

"....os grandes jornais (no caso, paulistas) arrogam o papel já definido pelo liberalismo clássico de um quarto poder ou o poder fiscalizador dos desmandos dos três outros que compõem as democracias modernas. Mas além de um poder investido (nem sempre legitimado com total aprovação da sociedade) e auto-proclamando para se contrapor aos governos e demais instâncias institucionais, a imprensa, sob a alegação de defender os interesses sociais, avoca a si a formação das opiniões. Em primeiro lugar fala com os lideres de opinião, ouve-os constantemente num círculo vicioso - ou seja, dá espaço majoritariamente para os vocalizadores consagrados e que representam grupos organizados e também querem fiscalizar ou se contrapor ao governo (este, uma instância abstrata na maioria das vezes, da qual emana o Mal). Do círculo viciado se irradiam os sentidos formadores da opinião pública." 
Segundo Medina (1998), embora a Secretaria do Meio Ambiente tenha se empenhado em difundir dados e propostas, como a do transporte sustentável e aspectos de cidadania, a operação foi associada às facilidades do trânsito, em que "todo o raciocínio gira em torno do governo, não em torno da vida..........a única concepção latente de vida nas coberturas é a do serviço imediato; o acompanhamento incidental de comportamentos sociais quase sempre discordantes; a atenção constante às falhas de fiscalização e às liminares das multas; a vocalização dos prejuizos econômicos e a capacidade de dar um jeitinho, driblando a legislação."

Dessa forma, podemos notar que embora a populaçăo no decorrer da operação sinalizasse um apoio e uma aceitação diminuindo a resistência ao rodízio, a imprensa, em seu importante papel exercido na divulgação e disseminação de informaçōes, teria um efeito mais significativo se aprofundasse as questōes voltadas para a qualidade de vida.

\subsection{RESULTADOS DA CAMPANHA}

Um folheto de agradecimento à população foi entregue no encerramento da campanha nos principais pontos de panfletagem da cidade. Foi registrada, segundo Operação Rodízio Relatório de Avaliação (CETESB, 1995,), através de pesquisas de opinião pública, a manifestação favorável de 
$64 \%$ a $90 \%$ dos proprietários de veículos e uma adesão voluntária de $38,1 \%$, alcançando um pico de $45,1 \%$.

O desempenho da campanha de 1995 em relação aos seus objetivos foi fraco, pela pouca adesão da população na avaliação da Defesa Civil, que a achou válida pela repercussão da cobertura jornalística que teve.

Desde a implantação da Operaçāo Rodízio, ficou estabelecido na Lei de Aprovaçāo que a CETESB emitiria relatórios contendo análise e diversos aspectos meteorológicos relativos à qualidade do ar na RMSP, como poluentes e ações de controle de fontes veiculares desenvolvidas pela Agência Ambiental, estimativas de reduçāo de poluentes e índices de obediência à Operação Rodízio.

No ano de 1995, conforme Operação Rodizio Relatório de Avaliação (CETESB, 1995), quando o rodizio foi introduzido, a CETESB registrou uma porcentagem de adesão, lembrando que o rodízio era voluntário, com uma média de $38,1 \%$. A avaliação do grau de adesão dos proprietários de veículos era feita através de análise estatistica da contagem de veiculos por final de placa. Foram realizadas pesquisas pelos veículos de comunicação, que em seus resultados apresentaram um percentual de manifestação de intenção de participar do rodizio por parte dos proprietários de automóveis, de $64 \%$ a $90 \%$, revelando a abrangência da divulgação da campanha. 
Os relatórios da Operaçāo Rodízio demonstram que a partir de 1996, quando o rodízio passou a ser obrigatório e começou haver aplicação de multas, o indice de adesão médio foi de $\underline{95,2 \%}$ em $\underline{1996}$. publicado no Relatório Balanço da Operação Rodízio 1996 (CETESB, 1996); 96,3\% em 1997, publicado no relatório Operaçāo Rodízio1997 - Respira São Paulo (CETESB, 1997) e $\underline{96,7 \%}$ em 1998, publicado no Relatório Operação Rodízio 1998 (CETESB, 1999). Como benefícios sociais mensuráveis, apresentou:

- Aumento da velocidade média dos veículos leves;

- Aumento da velocidade média dos ônibus urbanos na RMSP;

- Aumento do número de viagens realizadas por ônibus urbanos no Município de São Paulo sem aumento da frota;

- Redução média de congestionamento;

- Reduçāo do tempo de viagem devido à melhoria no trânsito;

- Combustivel economizado;

- Reduçāo do número de acidentes sem vítimas;

- Redução do número de veículos quebrados nas vias do Município de São Paulo;

- Redução do tempo de viagem devido à melhoria no trânsito;

- Redução da emissão de poluentes (além da redução de monóxido de carbono, partículas inaláveis, óxido de enxofre, óxido de nitrogênio e hidrocarboneto). 
Conforme apontadas no relatório, as condiçōes meteorológicas foram as piores no ano de 1995, criando condições desfavoráveis para dispersão de poluentes, porém indicando que as concentrações de monóxido de carbono, típicas de veículos, foram menores. No período de 1996 a 1998, houve uma redução relativa de monóxido de carbono, com média de $19 \%$ nos índices, conforme pode-se observar na tabela a seguir:

TABELA 5: Reduçāo relativa de monóxido de carbono de acordo com as fontes

\begin{tabular}{|c|c|c|c|c|c|c|c|c|c|}
\hline Fonte & \multicolumn{3}{|c|}{$\begin{array}{c}1996 \\
(\%)\end{array}$} & \multicolumn{3}{|c|}{$\begin{array}{l}1997 \\
(\%)\end{array}$} & \multicolumn{3}{|c|}{$\begin{array}{c}1998 \\
(\%)\end{array}$} \\
\hline & $\begin{array}{l}\text { SEM } \\
\text { rodizio }\end{array}$ & $\begin{array}{c}\text { COM } \\
\text { rodizio }\end{array}$ & $\begin{array}{c}\text { differen } \\
\text { ça }\end{array}$ & $\begin{array}{l}\text { SEM } \\
\text { rodizio }\end{array}$ & $\begin{array}{c}\text { COM } \\
\text { rodizio }\end{array}$ & $\begin{array}{c}\text { diferen } \\
\text { ca }\end{array}$ & $\begin{array}{l}\text { SEM } \\
\text { rodizio }\end{array}$ & $\begin{array}{c}\text { COM } \\
\text { rodízio }\end{array}$ & $\begin{array}{c}\text { diferen } \\
\text { ca }\end{array}$ \\
\hline Indústrias & 3,4 & 3,4 & 0,0 & 2,0 & 2,0 & 0,0 & 3,6 & 3,6 & 0,0 \\
\hline Motos & 3,2 & 3,2 & 0,0 & 1,7 & 1,7 & 0,0 & 3,7 & 3,7 & 0,0 \\
\hline Táxis & 3,7 & 3,3 & 0,4 & 2,0 & 1,8 & 0,2 & 3,4 & 3,1 & 0,3 \\
\hline $\begin{array}{l}\text { Önibus/ } \\
\text { Caminhões }\end{array}$ & 15,8 & 13,4 & 2,4 & 21,3 & 19,2 & 2,1 & 17,0 & 14,4 & 2,6 \\
\hline $\begin{array}{l}\text { Caminhonetas } \\
\text { A diesel }\end{array}$ & 2,5 & 1,9 & 0,6 & 7,0 & 5,4 & 1,6 & 2,6 & 2,0 & 0,6 \\
\hline Automóveis & 71,4 & 55,0 & 16,4 & 66,0 & 50,8 & 15,2 & 69,7 & 54,2 & 15 \\
\hline TOTAL & 100 & 80,2 & 19,8 & 100 & 80,9 & 19,1 & 100 & 81,0 & 19,0 \\
\hline
\end{tabular}

Obs.: Não obtivemos dados relativos a 1995.

Fonte: Adaptada dos relatórios da Operaçāo Rodizio do periodo de 1995 a 1999.

A Operação Rodizio, apesar da polêmica gerada, teve uma grande repercussão na sociedade e nos meios de comunicação, pois vieram à tona diversas questões relacionadas ao trânsito: congestionamentos, transporte coletivo, ocupação desordenada do solo urbano, como principais 
causas da poluição atmosférica exercendo influência direta na qualidade de vida dos paulistas, lembrando que nas eleiçōes para prefeito em 1996, praticamente todos os candidatos apresentaram propostas com soluções para o transporte urbano.

\subsection{ANÁlise do CASO NA ÓTICA DO MARKETING SOCIAL E COMUNICAÇÃO PERSUASIVA.}

Nesse tópico, apresentam-se e analisam-se as atividades principais de marketing do caso Operação Rodízio, estabelecendo uma comparação entre o referencial teórico do marketing social e comunicação persuasiva com os dados coletados.

É importante observar que o rodízio de veículos, conforme analisado nos dados secundários e primários, aparece como uma ação emergencial que apenas ameniza os impactos provocados no meio ambiente, decorrentes do excesso de veículos na cidade, enquanto se buscam soluções para problemas estruturais, considerando a realidade de São Paulo que cresceu de forma desordenada, tornando-se imprescindivel um planejamento integrado consolidando várias soluções que reúnam diversos esforços de decisão, integrando govemo federal, estadual, municipal e a sociedade civil. 
A Operação Rodizio foi uma das atividades desenvolvidas pela Secretaria do Meio Ambiente no combate à poluição, sendo focada como única alternativa de reduzir os problemas da poluição atmosférica na metrópole, visando buscar alternativas e uma iniciativa de mobilizar e agregar diversos setores da sociedade.

Lembrando que também existiram outras ações desenvolvidas como suporte e auxílio, como a operaçăo caça-fumaça, transporte solidário, etc., que resultaram na elaboração da proposta "Por um Transporte Sustentável" pelo Comitê Consultivo de Controle da Poluição de Transportes do Estado de São Paulo, visando integrar políticas públicas federais, estaduais e municipais de transporte, trânsito de veículos, energia, uso e ocupação do solo, saúde e meio ambiente.

É importante, assim, ressaltar o papel da administração pública e da Secretaria do Meio Ambiente na divulgação de campanhas públicas de informaçōes sobre os riscos ambientais que ameaçam os habitantes da metrópole, e não articular somente acordos e procedimentos sociopolíticos, criando mecanismos orientados para constituir um esforço comunitário, estimular e consolidar um processo eficiente de participação e conscientização.

As pesquisas de opinião nos documentos analisados mostraram que a população apóia o rodizio de carros mais pelo impacto provocado nas condições de trânsito da cidade do que pelos impactos 
ambientais, revelando que ainda não há uma consciência dos efeitos da poluição. De modo geral, a população não vê resultados no que se refere aos impactos ambientais, pois enquanto leigos, só entendem da poluição quando vêem fumaça, como as emitidas por ônibus, caminhōes e fábricas. A dos automóveis não é perceptivel, embora comprovadamente é um dos grandes responsáveis pela poluição urbana.

Também foi revelado nas pesquisas e nos documentos analisados que a Operação Rodízio constitui-se em um elemento de mudança de comportamento, pois iniciou um processo de discussão nas diversas camadas da sociedade sobre o meio ambiente. $O$ tema passou a ser incorporado no dia-a-dia mesmo daqueles que se posicionaram de forma contrária ao rodízio como solução para o problema ambiental, mostrando que a operação é uma prática que pode ser aplicada por outros órgãos governamentais em outras situaçōes, além da qualidade do ar, como na implantação da "Operação Horário de Pico" da PMSP como alternativa ou solução de trânsito.

Embora a Operação Rodízio tenha utilizado vastamente os recursos de comunicação e promoção, é importante ressaltar que para o sucesso de uma campanha dessa magnitude, os recursos devem estar inseridos em um direcionamento de marketing social, no qual a comunicação persuasiva esteja focada com os objetivos a ser alcançados no processo de mudança de comportamento, estimulando participação, conscientização e informação da população e ressaltando a importância do Governo no acesso 
à informação quanto aos riscos ambientais que ameaçam os habitantes, visando melhorar a qualidade de vida e saúde da população.

\subsection{O CONCEITO DE MARKETING SOCIAL DA OPERAÇĀO RODIZZIO}

Para a operacionalização da Operação Rodízio, foi constituído um grupo de trabalho multidisciplinar ligado diretamente ao gabinete do secretário que coordenava e articulava todas as ações do rodizio, que eram muito abrangentes pois englobavam toda a região metropolitana. O grupo foi constituido por decreto e integrado por jornalistas e técnicos de várias áreas de formação, porém não havia ninguém com treinamento ou da área de marketing, e se reuniam diariamente, inclusive aos sábados, quando eram distribuídas as tarefas para cada membro do grupo que ficava responsável por uma atividade.

Poucas ações públicas foram feitas como o rodízio que mobilizou toda a sociedade e foi realizado sem nenhum gasto para a SMAVCETESB, sendo realizadas várias articulaçōes com os diversos setores sociais, como taxistas, meios de comunicação, telemarketing, utilizando atores e personalidades públicas que aderiram voluntariamente sem receber alguma remuneração. 
Não havia uma estrutura formal de marketing, e o grupo traçava as estratégias de comunicação no sentido de persuasão do rodizio. A fiscalizaçāo e a multa tinham uma grande importância no processo para nāo desmoralizar a medida, pois a ausência de fiscalização desestimularia os que estavam cumprindo o rodizio, e as adesões eram grandes. O Grupo de trabalho, em conjunto com a sociedade civil, destinava os recursos para a área de meio ambiente, de acordo com as demandas, não havendo nenhum precedente no Brasil, e todas as informaçōes eram passadas para a imprensa, em total transparência.

Havia muitas situaçōes que nāo eram previstas, como os carros que vinham de outros Estados, trafegavam na região e eram multados, e a circulação de deficientes físicos e de seus acompanhantes. É importante ressaltar que não havia nenhuma experiência similar no Brasil.

A operação teve grande repercussāo junto à sociedade, nos meios de comunicação e nos diversos setores sociais, pois conseguiu despertar a conscientizaçāo sobre os problemas de poluição do ar que têm sérios efeitos na saúde humana, já que existem estudos comprovando que pessoas morrem em função do problema de poluição, e suscitar a discussão e o debate sobre os problemas e diversas questōes relacionadas ao trânsito, congestionamentos, transporte coletivo, ocupação desordenada do solo urbano, como principais causas da poluiçāo atmosférica, exercendo influência direta na qualidade de vida da populaçāo. 
Os entrevistados revelaram que a adoção do conceito de marketing social é imprescindivel e que ouvir o mercado para direcionar as ações é fundamental. Essa postura ficou evidenciada durante a operaçăo, na qual houve muito diálogo com os diversos agentes envolvidos em uma abertura de mão dupla. À medida que surgia um problema, os setores procuravam a SMA, que ouvindo os interessados e levando propostas aos mesmos, surgiam soluçōes criativas. A orientação dada pelo secretário era para que ninguém ficasse sem resposta, seja ela qual fosse.

Na direção do grupo, havia a preocupação com o marketing e que este deveria ser incorporado em suas ações, porém nāo houve um planejamento prévio, sendo recorrido ao que o sr secretário na entrevista chamou de "técnicas de guerrilhas", como as utilizadas pelas ONGs, nas quais o objetivo é gerar notícias e atrair a mídia, gerando notícia e o boca-aboca nas panfletagens, o que foi positivo por um lado, resultando em parcerias e criatividade.

Os entrevistados revelaram que houve a falta de uma campanha institucional mostrando os aspectos de saúde e melhoria da qualidade do ar após a operação, e que apesar de não haver nenhum assessor de marketing, à medida que a campanha ganhava visibilidade, a midia levantava questões e sugestōes que eram aceitas para melhorar o rodizio. 
A estratégia deu certo se analisada pelo fator de atenção e polêmica geradas. Porém, a SMA teve dificuldades em mostrar os benefícios do rodízio ambiental, que era uma medida provisória e emergencial e não definitiva, e que sem o rodízio, as condiçōes estariam piores, mas acabou evidenciando as questōes sobre os problemas urbanos, concentrando-se no tema transporte.

Apesar de haver uma preocupação com as informaçōes do mercado no desenvolvimento de estratégias promocionais e com açōes de marketing na comunicação persuasiva, se não houver uma integração no desenvolvimento do conceito de marketing de forma planejada, as atividades desenvolvidas serão ineficazes, $\circ$ que se pode constatar no comprometimento da disseminação do conceito da Operaçāo Rodízio.

\subsection{SISTEMA DE INFORMAÇŌES E PESQUISA}

As atividades de marketing existiam e estavam presentes, como a logística, a divulgação e outras, porém, não havia um sistema estruturado de informações e pesquisas. Muitas açōes foram feitas baseadas nas pesquisas de opinião que os jornais faziam e divulgavam, lembrando que havia um viés da imprensa. Embora houvesse a consciência 
de que o ideal era desenvolver as próprias pesquisas, com poucos recursos, a SMA ainda conseguiu desenvolver algumas pesquisas.

Os projetos da SMACETESB sofreram influência a partir de eventos ocorridos no meio ambiente, observando que um projeto como a Operação Rodízio envolve milhões de pessoas, impactando diretamente em seu cotidiano, embora o grupo interagisse com os setores sociais.

Para que a organização atinja seus objetivos, é necessário que ela estruture uma unidade de marketing com técnicos de diversas áreas de conhecimento e um sistema de informaçōes possibilitando conhecer as principais variáveis no meio ambiente em que ela opera, lembrando que a SMA/CETESB desenvolve outros projetos de cunho social que envolvem mudança de comportamento, e portanto, imprescindível para seu sucesso, a aplicação das ferramentas do marketing social.

O sistema deveria conhecer as mudanças que estāo ocorrendo nesse meio, identificando a capacidade e os segmentos escolhidos como alvo, e as adaptaçōes e ajustes que precisam ser feitas para manter um programa, bem como o desenvolvimento da comunicaçāo de forma mais focada para cada segmento adotado.

Conforme a literatura recomenda, o sistema de informações da SMAVCETESB poderia conter como subsistemas: 
- BANCO DE DADOS: Alimentado por informaçōes geradas pelo público interno em contatos feitos externamente. No caso da Operação Rodízio, com atendimento direto ao público (inclusive panfletagem), telemarketing; contatos com a imprensa, solicitação de entrevistas e pauta.

- Relatórios de participação de técnicos em congressos e seminários nacionais e internacionais.

- Discussões e informações sobre programas similares internacionais, apresentação de objetivos, entre outros.

- Informações sobre as diversas esferas de governo, monitorando sua evolução.

Lembrando que houve diversos seminários e discussões com os vários setores sociais, inclusive gerando o documento Por um Transporte Sustentável, notando-se que as informaçōes estavam descentralizadas, não apresentando um banco de dados unificado. Podendo conter, ainda nesse banco, um subsistema estatístico e de inteligência de marketing, com os levantamentos efetuados do grau de adesão, niveis de poluição, informações coletadas nos diversos grupos de trabalho gerados, contatos externos que foram feitos e a inclusão de conhecimento informal interno sobre as variáveis do mercado relacionadas ao combate à poluição e na defesa do qualidade do ar.

- PESQUISA DE MARKETING: Apesar de terem sido desenvolvidas algumas pesquisas, não se observou nenhuma direcionada para a imagem da organização visando verificar se suas açōes são bem 
comunicadas e percebidas pela sociedade como um todo. e se os serviços e produtos oferecidos estão de acordo com as suas necessidades e anseios. O que poderia auxiliar nas decisões e no planejamento de ações, focando os grupos de adotantes sobre os beneficios procurados na proteção ambiental.

A SMAVETESB comunica-se com diferentes segmentos e de diferentes formas, e a imagem de uma empresa é constituida de diferentes públicos com seus concorrentes/parceiros, analisando seus pontos fortes e fracos, que no caso estudado, concorre com outras empresas estatais por recursos orçamentários.

Assim, nesse contexto, um estudo sobre a imagem da SMAVCETESB é uma das principais ferramentas para entender o gap entre como ela almeja ser e é percebida. Dessa forma, permitir ajustes ou recomendações de suas estratégias de comunicação, notando que nas áreas de serviços, muitas vezes a imagem percebida é a única parte " tangivel " para seus clientes/usuários.

$\mathrm{Na}$ análise documental e nas entrevistas, não se constatou a existência de um planejamento e sistematização das informações sobre o ambiente de marketing e dos públicos envolvidos. Segundo os entrevistados, todos os setores sociais eram ouvidos, porém não se identificou o registro de informações em um banco de dados unificado. 
Porém na análise, notou-se que havia um esforço em obter e sistematizar as informações que pudessem auxiliar nas decisōes de marketing e de comunicação, como a utilização do telemarketing, Disque Rodizio, reuniões e contatos mantidos com os representantes de diversos setores. A Internet poderia ser melhor aproveitada na obtenção de informações criando uma sistematização das informações obtidas através de um canal direto, que embora existisse, não constituia um banco de dados.

\subsection{SEGMENTAÇÃO E POSICIONAMENTO DA OPERAÇÃO}

A segmentação de mercado consiste em uma abordagem que visa identificar e classificar grupos homogêneos baseados em um critério ou mais de variáveis que sejam comuns para todos os integrantes desse grupo. A finalidade da segmentação é possibilitar a organização e o desenvolvimento de um programa de ação para cada segmento, focando a comunicação e as necessidades desses grupos com características semelhantes.

$\mathrm{Na}$ análise documental e nas entrevistas, identificou-se que havia um critério informal de segmentação e que a comunicação era feita com esses grupos não de uma forma focada, pois à medida que surgiam problemas ou reivindicações de grupos e representantes de entidades, a 
SMA abria um canal de discussão, aceitando sugestōes, criticas e soluçōes, que eram muitas vezes obtidas conjuntamente.

Ou seja, os grupos especificos que tinham problemas com o rodízio procuravam a SMA, e o grupo do rodizio estabelecia a negociação, mas na maioria das vezes, a demanda partia dos próprios interessados, como as transportadoras que se sentiam prejudicadas, e as negociações eram sempre muito tensas (conforme relato de entrevistados). Quando a secretaria identificava uma necessidade, ela procurava o segmento para uma negociação.

Muitas açōes foram desenvolvidas como trabalho de conscientização para setores especificos, como postos de combustiveis, taxistas que tinham uma comunicaçāo diferenciada e também caminhoneiros, para os quais foi produzido um jornal em uma linguagem especifica. O grupo do rodizio conseguiu desenvolver muitas ações planejadas, como a distribuição de panfletos em associaçōes de supermercados, shopping centers, escolas, e diversos trabalhos focados incluindo a produção de uma revistinha infantil.

$\mathrm{Na}$ entrevista, foi relatado que houve o desenvolvimento de um trabalho com os donos de caminhões, e levantadas questões sobre os mesmos, pois a percepção da população aumentou em relação à "fumaça preta", que evidenciou um problema já existente e revoltava as pessoas que ficavam tolhidas de utilizar seu automóvel, enquanto que os caminhões 
podiam circular. Houve outros desdobramentos em relação aos caminhōes, e foi produzido um vídeo com a participação de uma cantora esclarecendo essa questão.

Observou-se que deveriam ser realizados estudos mais intensos visando determinar uma segmentação para a Operação Rodizio, o que possibilitaria estabelecer estratégias e objetivos de marketing diferenciados para atingir os diversos públicos adotantes da Operação Rodizio, ressaltando que a base para essa segmentação seria informaçōes geradas pelo Sistema de Informaçōes de Marketing - SIM.

Embora tenha ocorrido a segmentaçāo geográfica, com açōes junto aos postos, pedágios, etc., não foram açōes planejadas fundamentadas em um banco de dados com informaçōes que pudessem subsidiar a comunicação junto aos adotantes.

As açōes eram determinadas em reuniōes, conforme relato de entrevistados, notando-se que as decisões eram tomadas com o intuito de divulgar a operação em linguagem acessivel ao público escolhido, mas não eram associadas com o posicionamento do rodizio, até porque não havia especialistas ou pessoas integrantes da equipe treinadas em marketing. À medida que se ganhava visibilidade das questōes com a mídia, aceitava-se sugestōes da mesma. 
O critério de segmentação é uma etapa importante na elaboração de um programa de marketing, e no caso do produto "Operação Rodizio", é composto por profissionais liberais (médicos, advogados, entre outros), empresas, caminhoneiros, pessoas físicas com destino, rotas e rotina diversificados, como exemplo, levar/pegar filhos na escola, perueiros, taxistas, deficientes com automóveis, entre outros. O que poderia ser identificado em grandes grupos, como o empresarial e a população como um todo.

O produto "Rodizio" tem uma relaçāo estreita na maneira de identificar a finalidade com que 0 individuo ou organização trata o meio ambiente e a proteção ambiental, que pode ser útil para determinar os beneficios que $o$ indivíduo ou a organização obteria combatendo a poluição, contribuindo em deixar de rodar com seu veículo.

Percebeu-se um esforço da Operação em conhecer melhor seus segmentos de atuação e estabelecer ações voltadas para esses públicos-alvo, porém não se identificou como era decidida a prioridade de atuação no grupo do Rodízio. O que seria interessante, conduzir um estudo sobre as variáveis psicográficas e comportamentais, lembrando que nas pesquisas de opinião que foram efetuadas pelos próprios meios de comunicação, havia um viés nos resultados, e muitas ações foram baseadas nesses trabalhos, além das outras fontes, como os canais abertos de diálogo. 
Quanto ao posicionamento, a SMAVCETESB deveria mostrar sua capacitação técnica em solucionar problemas em questões ambientais, - que a habilita na condução de ações de mobilização social na liderança de açōes de controle da poluição do ar, demonstrando que é responsável pelos recursos que recebe e que seus valores são adequadamente utilizados, justificando a aplicação da multa.

No caso da Operação Rodízio, apesar de toda transparência sobre a destinação dos recursos, a SMACETESB é reconhecida por ser uma das maiores agências ambientais do mundo. Possui muitos dados e estudos que deveriam ser transformados em informações para ser transmitidas à população em linguagem clara e não técnica, contribuindo e demonstrando sua capacidade em solucionar problemas ambientais.

\subsection{COMPOSTO DO MARKETING SOCIAL}

\section{PRODUTO}

Conforme conceituado por Kotler (1998, p.383), "produto é algo que pode ser oferecido a um mercado para satisfazer a um desejo ou necessidade" e inclui..."bens físicos, serviços, pessoas, locais, organizações e idéias. "Nesta afirmação, nota-se que o autor em sua definição demonstra 
que o produto é algo que está sendo oferecido ao mercado, independente de como ele está sendo apresentado.

Partindo dessa definição do que seja produto, Kotler (1998), em sua visão, relata que ao planejar a oferta no mercado, uma organizaçāo deve considerar outros niveis de produto, sendo que cada um deles acrescenta um valor, e o conjunto constitui uma hierarquia para o consumidor.

Esses niveis partem do beneficio-núcleo que constitui o serviço ou o beneficio fundamental que o consumidor está realmente comprando. A empresa, então, transforma esse benefício em um produto básico e vai ampliando-o para os outros niveis do produto.

Da definição de benefício procurado pelo consumidor, 0 autor amplia o conceito de produto dividindo-o em produto tangivel, genérico e ampliado.

O produto genérico é reconhecido como a oferta ao mercado-alvo e consiste em objeto, serviço, pessoas, idéias, sendo caracterizado basicamente pelo nivel de qualidade, estilo, embalagem e marca.

Nas outras duas dimensões, é agregado um valor subjetivo ao produto tangível, que simplesmente é a embalagem de um produto 
genérico ou benefício. O produto genérico é relativo ao benefício ou utilidade essencial que está sendo procurado pelo comprador, como exemplo, uma mulher que compra um batom está adquirindo beleza, e não um conjunto de atributos químicos.

O produto ampliado é a totalidade dos benefícios que um indivíduo recebe, relativo ao total de serviços e custos agregados ao produto, objetivando atender às expectativas do mercado-alvo. 0 autor ressalta que a tarefa do especialista em marketing consiste em vender benefícios e não aparências, dessa forma, deve compreender os benefícios procurados partindo da ótica do consumidor.

Para Levitt (1995), produto é "... conseguir satisfazer clientes de modo total - é algo que pode ser administrado". Em sua visão, o autor demonstra que a aquisição de um produto pelas pessoas é motivada pelo desejo em resolver um problema e que o produto só tem valor pelo ponto de vista do comprador que percebe e atribui valor através dos benefícios que quer receber.

Segundo Levitt (1995), os produtos podem ser tangiveis e intangiveis, sendo que os tangiveis podem ser experimentados diretamente, vistos, tocados e testados, e isto pode ser feito antes da aquisição, enquanto que o intangivel é o inverso. $O$ autor ressalta que sua diferença é muito subjetiva, argumentando que os tangiveis podem ser experimentados e têm 
uma parte de intangibilidade. Lembrando, como exemplo, um computador que deve ser instalado como recomendam as instruçōes.

No mix de marketing desenvolvido pela SMAVCETESB na Operação Rodízio, convém observar que a redução da poluição atmosférica provocada por veículos é derivada de benefícios que impactam diretamente na qualidade de vida e saúde das pessoas e no meio ambiente, reduzindo o fluxo de trânsito e o consumo de combustiveis. No caso estudado, identificam-se também serviços prestados e instalaçōes de equipamentos, como estações medidoras.

É importante ressaltar que a SMACETESB atua com produtos intangiveis e necessita de um estruturação e implementação muito cuidadosa na estratégia de produtos. Assim, quanto ao produto genérico, a ênfase nas ações educacionais se mostrou presente na abordagem da Operação junto às escolas e à sociedade, visando provocar uma mudança de valores com ações voltadas para os jovens e as crianças, com a intenção de conscientizar sobre a importância de medidas no combate à poluição.

O desenvolvimento de novos produtos de conscietizaçāo da proteção ambiental poderia ser divulgado e disseminado na sociedade. 


\section{PREÇO}

Conforme observam Kotler; Roberto (1992), o preço desempenha diversas funçōes, e os administradores de marketing ao planejar uma campanha social devem considerá-las.

Os autores lembram que as funções podem ser de acessibilidade, posicionamento do produto e de reduçăo do marketing. $\mathrm{Na}$ função de acessibilidade, os preços interferem na aquisição do produto pois, se forem altos, dificultam a compra, e se forem baixos, ocorre o inverso.

A função de posicionamento do produto serve de símbolo ou indicador da qualidade do produto, observando que os preços também comunicam, pois se um grupo de adotantes tem dificuldades em julgar a qualidade do produto social, ele usa o preço como padrão. E, nesse caso, se for um valor alto, o grupo tende a acreditar que o produto é de alta qualidade ou tem muito prestígio, já em um produto de preço inferior ou gratuito, acredita-se que seja de má qualidade. Citando como exemplo, os serviços de saúde pública.

Na função de redução do marketing, os autores apontam que o preço desempenha o papel de reduzir a demanda quando ela é excessiva ou indesejável. Existe ainda a redução da demanda quando a demanda do programa social é maior do que a capacidade da oferta, e ressaltam que os quatro "Ps" são utilizados para conseguir essa redução. 
No caso da "Operação Rodízio", a aplicação de multas tinha o propósito de moralizar e reforçar a restrição de circulação de veículos e, através da utilização da promoção e divulgação, persuadir o motorista a utilizar meios alternativos de transporte. Quanto aos recursos das multas aplicadas, ficou estabelecido que o montante seria revertido em projetos ambientais.

Convém observar que a população não percebeu que reduzindo a circulação de veículos estaria contribuindo para melhorar o ar da cidade e que os recursos captados com a aplicação das multas seria revertido em beneficio da comunidade, uma vez que os mesmos deveriam ser alocados em projetos ambientais.

\section{DISTRIBUIÇÃO}

De acordo com Kotler; Roberto (1992), após o planejamento de um produto social, os especialistas em marketing devem direcionar sua atenção para a oferta, pois "se um produto social não puder ser encontrado, os adotantes escolhidos como alvo não poderão agir com base nas informações e na persuasão transmitidas pelas atividades promocionais." 
Dessa forma, Kotler; Roberto (1992) ressaltam a importância do planejamento na distribuição de um produto, afirmando que ".. um canal de distribuição é uma rede de instituições e agências dedicadas à tarefa de levar os produtos de produção para os pontos de consumo' . De acordo com os autores, (..)em marketing social, o ponto de produção é a campanha de mudança social e os pontos de consumo são os adotantes escolhidos como alvo. A administração de um canal de distribuição envolve o gerenciamento de uma rede de intermediários."

No caso da Operação Rodízio, a idéia de proteção ambiental para ser ofertada corretamente, através da restrição de circulação de veiculos, deve utilizar em sua distribuição uma rede de instituições e agências que leve a idéia do produtor para os pontos de consumo.

Como canais de distribuição, foram utilizados os órgãos integrantes do sistema de meio ambiente e foram desenvolvidas parcerias com entidades relacionadas aos grupos de adotantes, como postos de gasolina, supermercados, sindicatos, escolas e os canais de mídia impressa e eletrônica, que auxiliavam na distribuição dos materiais produzidos e nas ações de conscientizaçāo e persuasāo.

Conforme observado na literatura, a SMACETESB, visando solucionar conflitos de canais promoveu reuniões com as entidades representativas dos grupos adotantes, como o de transporte de produtos 
pereciveis e deficientes físicos, estudando a viabilidade de concessōes quanto à circulação de seus veiculos.

A solução de conflitos também ocorreu através dos meios legais, pois conforme análise documental, foram desencadeadas várias açōes contra a SMAVCETESB questionando a legalidade da medida. Quanto à aplicação de multas do rodízio, foi desenvolvido um serviço de atendimento à população para receber, analisar e encaminhar o pedido de recursos para uma solução. Também foi implantando o Disque Rodizio, que visava esclarecer dúvidas e orientar o procedimento para encaminhar recursos de multas.

\section{PROMOÇÃO E COMUNICAÇÃO PERSUASIVA}

Segundo Kotler (1998), a promoção de vendas "consiste de um conjunto de diversificação de ferramentas de incentivo, em sua maioria a curto prazo, que visa estimular a compra mais rápida elou em maior volume de produtos/serviços específicos ou consumidores ou comerciantes". $\mathrm{Na}$ ótica do autor, ele demonstra uma diferença entre propaganda e promoção.

Ou seja, a propaganda oferece uma razão, e a promoção oferece um incentivo para a compra. A promoção, segundo o autor, é 
utilizada pela maioria de organizações, lembrando que as suas ferramentas variam em termos de objetivos especificos e que existem muitas ferramentas que estão disponiveis, como brindes, feiras, programas de fidelização, adesivos, e outros. Porém em sua avaliação, o especialista de marketing deve considerar o tipo de mercado, as condições competitivas e o custobeneficio.

O autor lembra que nos objetivos da propaganda existe uma classificação conforme o propósito, que pode ser o de informar, persuadir e lembrar.

Em informar, o objetivo da propaganda é comunicar como funciona um produto ao mercado, descrever os serviços disponiveis, reduzir receios e corrigir falsas impressões, além de construir uma imagem da empresa.

Quanto a persuadir, o autor comenta que o objetivo é voltado a desenvolver preferência e encorajar a mudança de marca, mudar a percepção dos compradores em relação aos atributos de um produto e persuadir os consumidores a comprar e receber visita de vendedores. $E$, no objetivo de lembrar, manter o produto na mente e em posição privilegiada dos compradores e de sua necessidade.

É bom lembrar que para utilizar a promoção e todos os instrumentos do composto de comunicação para obter seu sucesso, esses 
instrumentos devem estar integrados ao mix de marketing, conforme recomendado na literatura, e que todos os recursos de promoção, como publicidade, venda pessoal, propaganda, promoção de vendas e relaçōes públicas e suas ferramentas especificas, são importantes, não podendo um recurso ser mais enfatizado do que o outro, pois cada um depende das circunstâncias e necessidades de utilização.

Kotler (1998) observa algumas ferramentas de comunicação mais comuns utilizadas, como propaganda através de anúncios impressos ou projeçōes cinematográficas, rádio, televisão, encartes, catálogos, folhetos anuários, cartazes, materiais audiovisuais, simbolos e logos, videotaipes; promoção de vendas, brindes, exposiçōes, programas de fidelização, distribuição de adesivos, entretenimento; relações públicas, kits e apresentaçāo para a imprensa, seminários, relatórios anuais, patrocínios, publicações, relaçōes com a comunidade, midias especiais, eventos; venda pessoal, apresentação e convenção de vendas, programas de incentivo, e distribuiçāo de amostras e marketing direto, catálogos, listas de clientes, telemarketing, compra eletrônica, correio de voz, e-mail e fax.

$\mathrm{Na}$ Operação Rodizio, as atividades promocionais foram utilizadas com o objetivo de promover a proteção ambiental, divulgar os efeitos da poluição na saúde humana e dar credibilidade a medida.

O secretário sofreu várias críticas, como querer se autopromover, sair a campo e liderar espaços de mídia, que no início da 
campanha, como a de 1995, era voluntária. Ele não sabia se a população estava suficientemente informada sobre o rodizio, o que serviu de experiência-piloto para as demais, além da amplificação da mídia que, em muitos casos, se posicionou contra o rodizio.

Com a desconfiança da mídia quanto à aceitação por parte da população, a estratégia de comunicação foi enfatizada com a orientação de operar mais informaçōes à mídia. Para isso, utilizou o recurso promocional de kits e informativos para a imprensa, que eram enviados aos jornais, e a realização de entrevistas coletivas diariamente, com informaçōes sobre qualidade do ar, saúde, niveis de poluição e muitas outras informações. Dois jornalistas foram destacados para atuar na relação com jornalistas-chave e na seleção de entrevistas e participação de programas de televisão e rádio.

Foram feitas várias mediçōes estatísticas de adesão de veículos visando comprová-la para a imprensa e dar credibilidade ao programa. Posteriormente, foram realizadas algumas pesquisas pela própria secretaria, como a do "Perfil do Infrator", e produzido um grande volume de publicações, debates, seminários e eventos nacionais e internacionais, que evidenciaram que os mesmos foram realizados mais com o intuito de comprovar a efetividade da medida do que buscar subsidios mercadológicos que pudessem auxiliar no direcionamento das açōes de marketing. 
Na avaliação do secretário entrevistado, o rodízio ambiental (estadual) foi deficiente em mostrar aspectos positivos no caráter preventivo como uma medida provisória e emergencial e não definitiva, evidenciando o rodizio da prefeitura (municipal) mais facilitador em relação ao trânsito, mas que não resolve o problema dos transportes.

A promoção sempre foi a atividade mais desenvolvida na Operação Rodizio e foi utilizada nas três formas de comunicação, ou seja, comunicação de massa, seletiva e pessoal, sendo considerada como a principal forma de se relacionar com o mercado, e suas açōes promocionais não eram sistematizadas estabelecendo um cronograma para implementação de suas ações, embora utilizassem todos os instrumentos.

Segundo os entrevistados, a comunicação de forma geral não era segmentada, pois era voltada para a população como um todo, gerando muita polêmica no cotidiano das pessoas que moram na região metropolitana, e o alvo do rodízio era os usuários de automóveis. Mas os grandes beneficiários eram os usuários de ônibus.

Com a ação do transporte solidário, foi realizada uma parceria com o jornal "Folha de São Paulo", encartando para o Brasil inteiro cópia do CD-rom desenvolvido pela SMA divulgando a idéia do projeto (carona), e foi realizado com a USP o cadastramento de pessoas que moravam em locais próximos. Outra grande ação de divulgação foi a 
distribuição de folhetos com informaçōes sobre os efeitos da poluição na saúde, entregues aos pais em campanha de vacinação infantil.

Nas entrevistas, quando foram questionados os critérios para utilização dos instrumentos de promoção, os entrevistados afirmaram que não havia um planejamento, sendo que os critérios básicos eram a disponibilidade e a viabilidade dos recursos, ressaltando que pela falta de recursos financeiros, não havia contratação de agências de publicidade. As que participaram do processo eram convidadas ou procuravam a SMAVCETESB para estabelecer parceria.

As mensagens, textos e slogans eram desenvolvidos e criados pelo grupo, e não havia verba para publicidade. Todos os gastos com divulgação e elaboração de material foram financiados com patrocinio da iniciativa privada. Segundo os entrevistados, evidenciou-se que as atividades de logística e distribuição estavam presentes, mas não havia um planejamento prévio, e por não possuir recursos para açōes específicas, como pesquisas que eram baseadas nas publicadas pelos jornais não havia feedback. Porém, nota-se a inexistência de um sistema de inteligência de marketing, que poderia ser alimentado com recursos existentes e sem muito dispêndio financeiro.

Havia a preocupaçāo em treinar o pessoal que fazia panfletagem para não ser simples entregadores de material, mas sim 
agentes multiplicadores boca a boca, o que consistia na venda pessoal, conscientizando e informando a população.

A comunicação de massa estava presente na propaganda que era realizada em anúncios de jornais, rádios, cinemas e outros meios que objetivavam divulgar a Operação Rodizio. A publicidade era desenvolvida publicando artigos em jornais e revistas, e havia ainda a posição de alguns veículos que se posicionaram contra a medida divulgando noticias e pesquisas, de certa forma, direcionadas.

A promoção também foi utilizada através de seminários, cursos, palestras e debates desenvolvidos em açōes que englobavam diversos públicos adotantes, como escolas, universidades, entidades de classes, e até a atividades no desenvolvimento de legislação específica, como a formulação de um projeto de lei para transporte sustentável.

Foram desenvolvidos diversos materiais, como folders, CDrom, revistinhas, cartazes, publicaçöes e diversos recursos como telemarketing, etc. As atividades de relaçōes públicas eram exercidas por membros da equipe ligada ao secretário, que participavam de entrevistas e debates em rádio e televisão, além de ser agentes multiplicadores da operação e da idéia do rodizio.

Sobre o questionamento de como era avaliado o retorno da promoção, os entrevistados afirmaram que não foi formulada uma 
metodologia específica, baseados nas mediçōes estatísticas realizadas pela SMAVCETESB, em termos de adesão, e nas pesquisas de opinião publicadas pelos jornais, evidenciando a falta de um planejamento e direcionamento das ações e objetivos, previamente estabelecidos em um plano de marketing, ou a utilizaçăo de informaçōes de um SIM.

Apesar de a Operação Rodízio não ter uma sistematização de planejamento e avaliação das ações promocionais, havia a preocupação com essas atividades, caracterizada pela formação de uma unidade de jornalistas destinada a desempenhar esse papel, atuando em diversas frentes.

\section{PLANEJAMENTO E CONTROLE}

O planejamento de marketing é uma das principais funções administrativas que consistem em um processo contínuo de antever uma situação desejada no futuro, partindo de açōes a ser seguidas no presente, para atingir essa situação através de um documento que estabeleça os objetivos de uma instituição em um periodo de atividades, definindo as ações para se alcançar os objetivos. 
Em relação ao planejamento de marketing, não se identificou a elaboração de um plano de marketing formal e das demais atividades, apesar de haver a formalização de diversas ações desenvolvidas através de decretos e leis, para sua operacionalização, mas não constituindo um planejamento formal, pois conforme mencionado anteriormente, as decisōes e ações a ser executadas eram realizadas em reuniōes do grupo do rodizio e centralizadas no secretário da pasta.

Um fato importante a ser considerado é que no planejamento das ações, havia a preocupação de envolver toda a equipe do grupo nas discussōes e na elaboração das propostas, e os membros se tornaram agentes multiplicadores em entrevistas e debates.

Conforme recomenda a literatura, as açōes de marketing deveriam estar centralizadas em uma unidade constituída formalmente, onde pudesse ser sistematizadas as informaçōes de um SIM, e na elaboração de um plano de marketing envolvendo e informando o corpo técnico para participar da sua elaboração, criando mecanismos mais efetivos.

Apesar do planejamento informal, o que se pode observar é que as ações de uma certa forma estavam voltadas mais para justificar e obter credibilidade junto aos veículos de comunicação, como os próprios mecanismos estatísticos de medição da adesão, que eram utilizados como instrumentos de controle, demonstrando um conflito no canal de distribuição da mídia. As informaçōes coletadas poderiam ser melhor direcionadas para 
balizar as ações se sistematizadas e estruturadas em um SIM. A determinação dos objetivos de marketing era mais voltada para o operacional e também voltada para a disseminaçāo da idéia da Operação Rodizio como proteção ambiental.

De acordo com a sugestão da literatura, o que deveria ser feito era analisar os principais segmentos de atuação e os principais fatores do ambiente que poderiam interferir no desenvolvimento de estratégias e atividades dos concorrentes, que no caso da Operaçāo Rodizio, foi o próprio rodizio municipal, batizado de "Operação Horário de Pico", que obteve maior aceitação da população por ser percebido como um faciltador do trânsito, e só conseguiu ser implantado por mostrar benefícios que eram evidenciados pela própria Operação Rodizio, cabendo a ressalva de que a mídia enfatizava a melhora das condiçōes de trânsito e acentuava o conflito gerado entre Prefeitura e Estado na questão do I/M. 


\section{CAPÍTULO 6 - CONCLUSÕES, RECOMENDAÇŌES E LIMITAÇÕES}

\subsection{CONCLUSŌES E RECOMENDAÇÕES}

De acordo com a literatura, o conceito de marketing social ainda não está incorporado na cultura do sistema de meio ambiente que tem uma visão muito técnica das questões ambientais. Apesar de existirem departamentos e setores que atuam em atividades ligadas diretamente ao público, não existe uma unidade responsável pelo marketing. As atividades acabam sendo desenvolvidas por iniciativas isoladas com a utilização de recursos de comunicação, sem um planejamento formal ou um estudo sobre os públicos adotantes focando objetivos e metas a serem alcançados, que apenas utilizando recursos de comunicação não garantem o sucesso nos resultados.

Na caso da Operação Rodízio, constatou-se a necessidade da criação de procedimentos formais que sejam desenvolvidos envolvendo as decisões técnicas que devem ser elaboradas em conjunto no 
relacionamento com o público da SMACETESB, bem como na elaboração de novos produtos.

Em relação à função e às atividades de marketing, pode-se dizer que apesar de não sistematizarem as informações, demonstraram a preocupação da organização em conhecer melhor seu público-alvo. Constituíram uma equipe interdisciplinar e um grupo de jornalistas destacados especificamente para lidar com questões ligadas à comunicação, abrindo canais com os diferentes públicos.

Recomenda-se, portanto, que a SMACETESB desenvolva um SIM, que além dos dados gerados internamente, possa coletar, triar e disseminar 0 conceito de proteção ambiental, e ainda estruturar e profissionalizar formalmente uma unidade de marketing com legitimidade, para não sofrer contratempos ou até sua desativação por causa das mudanças políticas que podem ocorrer.

Não existe um sistema de informaçōes de marketing, e o recurso da Internet é pouco explorado, existindo dois sites específicos para cada entidade, ou seja, um da SMA e outro da CETESB, e no período analisado, a responsabilidade em responder os e-mails recebidos estava em uma área técnica no caso da CETESB, gerando uma certa lentidão nas respostas, contrariando a utilização desse instrumento que é a de interação com o público e a rapidez. 
As pesquisas desenvolvidas durante a Operação Rodízio, em sua maioria, foram elaboradas pela mídia e serviam de subsídio para tomada de decisões do grupo executivo ligado ao secretário, que em muitos casos havia um viés em seus resultados. Foram poucas as pesquisas qualitativas desenvolvidas pela SMA, e muitas quantitativas em relação ao número de adesão, volume de multas aplicadas e outras informações.

Entre os entrevistados, havia a percepção da necessidade de se realizar outras pesquisas qualitativas, mas o fator recurso financeiro foi um dos limitadores. Sugere-se a elaboração de outras pesquisas. Visando identificar e conhecer melhor seu público-alvo, focando melhor suas ações e a comunicação persuasiva.

Quanto à segmentação, não se identificou nenhum critério em sua utilização ou estudo no sentido de identificar público-alvo ou conhecer suas necessidades, embora houvesse 0 reconhecimento de segmentos específicos e grupos de adotantes recomendando a utilização do critério de benefício procurado.

A campanha englobava diversos segmentos, com várias necessidades sendo desenvolvidas, algumas ações pontuais, mas sem atender às necessidades latentes da sociedade, sendo preciso descobrir qual o benefício que poderia motivar o público-alvo e qual o melhor canal de comunicação a ser utilizado. 
Para essa atividade, seria necessário o desenvolvimento de pesquisas qualitativas para identificar os benefícios procurados nos principais grupos de adotantes, e como mencionado anteriormente, a SMA não dispunha de recursos financeiros para gastos adicionais.

O posicionamento da operação não foi bem definido e não conseguiu atingir seus objetivos em mostrar o rodízio como proteção ambiental, com os reflexos e os impactos na saúde da população. A SMA teve dificuldades em mostrar seus benefícios, sendo enfatizada a melhora do trânsito, que era mais tangivel, pois a população só começou a tomar consciência da poluição ao observar a fumaça preta emitida por caminhões.

O posicionamento foi confuso, e as mensagens e os slogans desenvolvidos para a campanha eram elaborados em reuniōes, sem um direcionamento preciso sobre o público-alvo a ser atingido ou um conhecimento prévio do mesmo, pois como apontado na pesquisa de campo, não havia um planejamento, e as soluções eram encontradas conforme a necessidade.

Desde o início da campanha, observou-se que havia um conflito entre a secretaria e a mídia, e que a estratégia adotada para intensificar as informações utilizando as ferramentas de comunicação persuasiva não atingiu o objetivo, constatando conforme a literatura recomenda, que sem um direcionamento de marketing, não adianta utilizálas de forma intensa se não estiverem direcionadas para os objetivos a ser 
alcançados, bem como para a utilização de todo o composto de comunicação.

A propaganda e a publicidade veiculadas tiveram alta exposição e visibilidade. Os recursos foram obtidos através de patrocinadores da iniciativa privada. Muitas agências de publicidade procuraram o órgão para fornecer patrocínio, vinculando a imagem da marca da SMAVETESB com a do patrocinador, descaracterizando a unidade da mensagem que estava sempre mais voltada a transmitir uma imagem de "amigo verde" do que preocupada com as causas ambientais. As mensagens eram elaboradas pelo próprio grupo da secretaria, de forma amadora, embora demonstrassem a preocupação com os recursos de comunicaçāo.

As atividades de relações públicas eram desempenhadas por membros integrantes do grupo de coordenação, e os mesmos não tinham formação na área, portanto, tornando imprescindivel para o sucesso da campanha, o auxílio de profissionais especializados nessa área de atuação ou de agências de publicidade contratadas para prestar serviços.

A atividade de promoção na maioria das empresas públicas é confundida com o marketing, justificando sua utilização de forma intensa e foi a mais desenvolvida pela SMAVCETESB. Porém, as ações promocionais realizadas não foram estabelecidas baseadas em um plano de promoção nem avaliadas em relação a sua eficácia, mas havia a preocupação no 
grupo com o papel desempenhado por alguns membros da equipe que atuavam como relações-públicas, mesmo não tendo formação profissional nessa área, tentando suprir uma deficiência e uma necessidade.

A venda pessoal foi realizada através do contato dos técnicos em ações de mutirões e panfletagem, além dos contatos realizados nos canais de negociação com os diversos segmentos. Recomenda-se que a mensagem a ser veiculada através dos diversos recursos deve estar contemplada no planejamento e composto de marketing, conforme identificação de necessidades e anseios de cada segmento, combinando e identificando o melhor canal a ser utilizado para o público-alvo a ser atingido.

A multa era enfatizada como uma medida de moralizar a Operação e dar-Ihe credibilidade, e portanto, associada ao preço, sendo dada pouca ênfase aos custos sociais envolvidos na Operação, como demonstrativos da redução em internaçōes e atendimentos médicos por problemas respiratórios durante o periodo do rodizio, quando comparado a outros períodos em que ela não foi realizada. A SMA divulgava dados sobre os benefícios sociais, mas eles eram associados aos benefícios do trânsito, economia de combustivel e outras informaçōes que reforçavam o benefício em relação ao trânsito, não sendo muito explorados os aspectos da saúde.

Desde o início da implantação da Operação Rodízio, não foi elaborado nenhum plano de marketing por falta de tempo e de profissional especializado nessa área. No início, a experiência-piloto serviu para 
subsidiar as ações dos anos seguintes, quando passou a ser oficializado através de lei e decreto. Houve vários problemas não previstos até por falta de conhecimento de benefícios e necessidades esperadas pelos grupos de adotantes e público-alvo. As atividades de marketing e de comunicação persuasiva estavam presentes nas diversas atividades da Operação, porém - que se observou é que não foram utilizadas como recomenda a literatura.

Portanto, conforme recomenda a literatura, é importante que a SMA/CETESB desenvolva anualmente um planejamento de marketing, por ser esse um instrumento que possibilita conhecer constantememente as variáveis ambientais e o comportamento do consumidor, possibilitando o controle das ações de marketing.

\subsection{LIMITAÇÕES}

A primeira limitação é a pouca bibliografia existente sobre a área do marketing social em causas ambientais, levando a uma adaptação de conceitos e atividades da teoria do marketing tradicional.

Outra limitação encontrada é a metodologia, que por se tratar de um estudo de caso, as conclusões só podem ser aplicadas para a 
SMAVCETESB, não se aplicando a outras organizações que realizam o marketing ambiental.

Ainda como limitação, pode-se citar os entrevistados que eram vinculados ao grupo executivo da Operação Rodízio e que planejavam as ações de comunicação e promoção da Operação, podendo distorcer a realidade no que tange aos conceitos de marketing e comunicação persuasiva, sendo que os técnicos ou outros integrantes do processo poderiam apresentar outras opiniões.

Finalmente, outra limitação é a pesquisa de campo, que não considerou opiniões e atitudes dos adotantes e outros integrantes do público-alvo, limitando-se apenas às opiniões, comportamentos e atitudes dos entrevistados da Operação Rodízio. 


\section{REFERÊNCIAS BIBLIOGRÁFICAS}

- AGENDA 21: Conferência das Nações Unidas sobre meio ambiente e desenvolvimento realizada de 3-14 junho de 1992 no Rio de Janeiro. Reproduzido pela Secretaria do Meio Ambiente do Estado de São Paulo, 1997. 383 p.

- Administração de empresas - Enciclopédia de direção, produção, finanças e marketing. Editora Nova Cultura Ltda. São Paulo, 1988 In: RIO DE JANEIRO (Estado). ENCYCLOPAEDIA BRITANNICA - Serviço de Pesquisas- Título do Relatório Empresa Pública. N², pg27/5, Rio de Janeiro, [ca 1990]. Paginaçāo Irregular.

- BARRIZZELLI, N. Um modelo de coleta e Processamento de Informações para a Tomada de Decisões de Preços no Varejo. São Paulo, 1995. Tese (doutorado) - Faculdade de Economia, Administraçāo e Contabilidade, Universidade de Sāo Paulo. 138p.

- BARTELS, R. The Identity Crisis in Marketing. Journal of Marketing. v.38, n. 4,. October, p. 73-76, 1974.

- BENNETT, P. D.; KASSARJIAN, H. H. - O Comportamento do Consumidor, São Paulo, Editora Atlas S.A., 1975. 161 p.

- BONOMA, T. V., Case research in marketing: Opportunities, problems, and a process. Journal of Marketing Research. v. XXI , p. 199-208, 1985.

- BRASIL. Constituição (1988) Constituição da República Federativa do Brasil, Brasília, DF: Senado, 1988.

- BRASIL, Leis. Lei n. 9795 de 27 de abril de 1999; Dispōem sobre a educação ambiental, institui a Política Nacional de Educação Ambiental, e dá outras providências. Diário Oficial da União, Brasília, D.F. , n. 79 de 28. abril.1999. pág. I.

- Brunacci, A.; Coimbra, J.Á.A.(org.) CETESB 25 anos: uma história passada a limpo, São Paulo, CETESB,1994.168p.

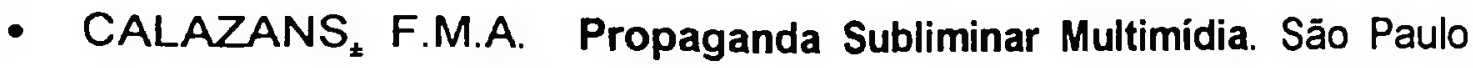
Summus Editorial, 1992.116p. 
- CAMPomar, M. C. Do uso de "estudo de caso" em pesquisas para dissertações e teses em administração. Revista de Administração, São Paulo, v.26, n.3,p.95-97,julho/setembro, 1991.

- CASTRO, C. M. A prática da pesquisa. São Paulo, McGraw-Hill do Brasil, 1977.

- CETESB. Secretaria do Meio Ambiente. Operação Rodízio Relatório de avaliação. CETESB, São Paulo, set//1995. 70 p.

- CETESB. Secretaria do Meio Ambiente. OPERAÇĀo RODízIO 95: do Exercício à Cidadania. CETESB, 1996. 32 p.

- CETESB. Secretaria do Meio Ambiente. Balanço da operação rodizio 96 - Respira São Paulo, Secretaria do Meio Ambiente, agosto 1996. São Paulo. 31p.

- CETESB. Secretaria do Meio Ambiente. Operação Rodizio 96 - no caminho certo. CETESB, São Paulo1997. 112 p.

- CETESB. Secretaria do Meio Ambiente . Relatório Operação Rodízio 97 : Respira São Paulo. CETESB, São Paulo, 1997. 110 p.

- CETESB. Secretaria do Meio Ambiente. Relatório Final, Operação Rodizio 1997, Pesquisa Perfil do Infrator. CETESB. São Paulo, 1997. $60 \mathrm{p}$.

- CETESB. Secretaria do Meio Ambiente. Por um transporte sustentável: diretrizes e proposta preliminar de anteprojeto de lei de política de controle da poluição veicular e transporte sustentávelDocumento de Discussão Pública. Série Documentos Ambientais. CETESB, São Paulo, fevereiro de 1997. 227 p.

- CETESB. Secretaria do Meio Ambiente. Relatório, Efeitos da Operação Rodízio/98 na qualidade do ar na região metropolitana de São Paulo. CETESB, São Paulo, nov/1998 26 p.

- CETESB. Secretaria do Meio Ambiente. Relatório, Operação Rodizio 1998. CETESB, São Paulo, jan//1999. 54 p.

- COBRA, M., Marketing básico, 4ª ed. São Paulo. Editora Atlas, 1997. $552 p$ 
- CORRÊA, H. L.. O "Estado da Arte" da Avaliação de Empresas Estatais. São Paulo, 1986. 248p. Tese (Doutoramento) - Faculdade de Economia e Administraçăo, Universidade de Sāo Paulo.

- CRESPO; S. (coord). O que o brasileiro pensa sobre o meio ambiente, desenvolvimento e sustentabilidade. Pesquisa nacional, realizada pelo MMA-Ministério do Meio Ambiente, dos Recursos Hídricos e da Amazônia Legal; MAST(CNPq)- Museu de Astronomia e Ciências Afins; ISER - Instituto de Estudos da Religião, Rio de Janeiro, jan/fev 1997.

- DENSER, W. A. Sistema de Informaçōes em Marketing, um Modelo de Tratamento do Fluxo de Informaçōes de Marketing Não Estruturadas. São Paulo, 1979. Dissertaçāo ( Mestrado ) - Faculdade de Economia, Administração e Contabilidade, Universidade de São Paulo. $167 p$.

- DONAIRE, D. Gestão Ambiental na Empresa. São Paulo, Editora Atlas S.A., 1995. 134p

- DUHAIME, C. P.; TAVISH, R. Mc; ROSS, C. A. ; Social Marketing: An approach to Third-World Development, Journal of Macromarketing, p.3-13, Spring, 1985

- ENIS, B.M., Deepening the concept of marketing. Journal of Marketing, v.37, n.4, pg.57-62, oct, 1973.

- FOX, K. F.A. ; KOTLER, P. The Marketing of social causes: the first 10 years, Journal of Marketing, V. 44, n.4, p.24-33, (fall) 1980.

- GIL, A. C. Como elaborar projetos de pesquisa. São Paulo, Editora Atlas S. A., 1991.159p.

- GIL, A. C. Métodos e Técnicas de Pesquisa Social. São Paulo, Editora Atlas S.A.,1987. 206p.

- hanAN, S. A.; BATAlHA, B. H. L. Amazônia, Contradiçōes no Paraiso Ecológico. São Paulo, Cultura Editores Associados, 1995. 265p.

- Humberg, M.E., editor responsável. Cuidando do Planeta Terra: Uma estratégia para o Futuro da Vida. traduçăo: Lenke Peres Alves de Araújo, São Paulo: Editora CL-A Cultura, 1991. 246 p 
- HUNT, S. D. The nature and scope of marketing. Journal of Marketing, v. 40, n.3, p.17-28, july, 1976.

- JACOBI, P. (coord.). Poluição do ar em São Paulo e resposta da ação pública.. São Paulo, CEDEC/SEI - Centro de Estudos de Cultura Contemporânea/Stockholm Environment Institute. 1997. Cad. Cedec $n^{\circ} 60.78 p$.

- KOTLER, P.; LEVY, S. J. Broadening the concept of marketing. Joumal of Marketing, v. 33, n.1. january, p.10-15, 1969.

- KOTLER, P. ; LEVY, S. J. A new form of marketing myopia:.Rejoinder to professor Luck. Journal of Marketing, v.33, n.3, july, p. 55-57,1969.

- KOTLER, P.; ZALTMAN, G. Social marketing: an approach to planned social change. Journal of Marketing, V.35, n.3, july p. 3-12,1971.

- KOTLER, P. A generic concept of marketing, Journal of Marketing; V.36 n.3, april, p.46-54, 1972

- KOTLER, P; ROBERTO, E.L. Marketing Social - Estrágegias para alterar - Comportametno Público, Editora Campus Ltda, Rio de Janeiro, 1992, $392 p$

- KOTLER, P. Marketing. Edição compacta. São Paulo, Editora Atlas S.A., 1988. 595p

- KOTLER, P.; FOX, K. F. A. Marketing estratégico para instituições educacionais. São Paulo, Editora Atlas S.A., 1994. 444p.

- KOTLER, P. Marketing para organizações que não visam o lucro. São Paulo, Editora Atlas S.A.,1994 . 430p.

- KOTLER, P. Administração de Marketing - Análise, Planejamento Implementação e Controle . $5^{\prime}$ ed. São Paulo, Editora Atlas S.A., 1998. $725 p$

- KOTler, P.; ARMStrong, G. Principios de Marketing. Rio de Janeiro, Editora Prentice Hall do Brasil Ltda, 1998.

- LACZNIAK, G. R.; MICHIE, D. A. The social disorder of the brodened concept of marketing. Academy of Marketing Science, Journal of Academy of Marketing Science Summer, v. 7, n. 3, p.214-232, 1979.

- LACZNIAK, G.R. ; LUSCH, R. F.; MURPHY, P. E. Social marketing: its ethical dimensions. Journal of Marketing, v. 43, p.29-36, (Spring) 1979. 
- LAZER, W. ; KELLEY, E. J. Interdisciplinary contributions to marketing management. In: Managerial Marketing - Perspective and View points, Richard D. Irwin, Inc., Homewood, Illinois, 1962, Pg.586-606

- LEIS, H. R. Meio ambiente e educação para a cidadania: uma relação paradoxal. Debates sócio ambientais - Meio ambiente \& educação para a cidadania. CEDEC - Centro de Estudos de Cultura contemporânea - SP - Brasil. Ano II, n.7 jun-set, p.11-12,1997.

- LESCA, H. ; ALMEIDA, F.C. Administração Estratégica da Informação. Revista de Administração, v.29, n.3, jul./set, p.66-75 -. 1994.

- LEVITT, T. A imaginação de marketing. São Paulo: Editora Atlas S.A, $1995.261 p$

- LEVY S.J., KOTLER P. Toward a brader concept of marketing's role in social order. Academy of Marketing Science, Journal of Academy of Marketing Science Summer, v. 7, n. 3, p.232-238, 1979.

- LUCK D. J.; Broadening the concept of marketing: too far. - Journal of Marketing, v. 33, n.3, july p. 53-55, 1969.

- MATtAR, F. N. . Pesquisa de marketing - metodologia, planejamento, execução e análise. São Paulo, Editora Atlas S.A., 1994. v.1. 350p.

- MAZZON, J. A. Marketing Social: conceitos e Perspectivas de Utilização no Brasil. Revista de Administração, v.7, n.4, p.5-8, 1982.

- McCARTHY, E. J.; PERREAULT (Jr), W. D. Marketing Essencial - Uma abordagem gerencial e global. São Paulo, Editora Atlas S.A., 1997, $397 p$.

- MEDINA, C. Símbolos \& narrativas: rodizio 97 na cobertura jornalistica. São Paulo. Secretaria do Meio Ambiente, 1998. $245 p$

- O que o brasileiro pensa sobre o meio ambiente, desenvolvimento e sustentabilidade. Pesquisa nacional realizada pelo Ministério do Meio Ambiente, dos Recursos Hidricos e da Amazônia Legal; MAST(CNPq)Museu de Astronomia e Ciências Afins; ISER-Instituto de Estudos da Religião, jan/fev 1997. 
- OTTMAN, J. A. - Marketing verde - Desafios e oportunidades para a nova era do marketing. São Paulo, MAKRON Books do Brasil Editora Ltda, 1994. 190p.

- PORTER, M.E.; Estratégia Competitiva, Técnicas para Análise de

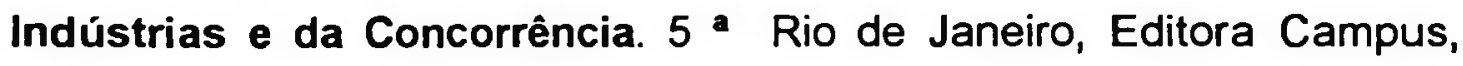
1991. 362p

- PORTER, M. E. - Vantagem Competitiva, criando e sustentando um desempenho superior. $5^{\text {a }}$ Rio de Janeiro, Editora Campus ,1992. 512p

- PORTER, M. E.; LINIDE, C. V.D. - Ser verde também é ser competitivo. Revista Exame, São Paulo, p. 72 a 78, 22.nov.1995.

- RATtNer, H. Desenvolvimento insustentável, Folha de São Paulo, São Paulo, 05 de novembro, 1995. Página 2.2

- Melhores e Maiores, Revista EXAME Junho de 1999 pg20 e 106

- ROCHA, A. ; CHRISTENSEN, C. Marketing - Teoria e prática no Brasil, São Paulo, Editora Atlas S.A., 1994. 350p

- SANTOS, A. S. R. A importância da educação ambiental, Jornal A TRIBUNA. Santos, 31 mai 1999, Tribuna Livre, p. A-3.

- SANTOS, J. R. Comunicação, Lisboa, Difusão Cultural, Sociedade Editorial e Livreira Ltda, 1992. 134p

- SANTOS, R. C. - Marketing e as questões ambientais, In: Anuais do II Encontro sobre Gestão Empresarial e Meio Ambiente, 1993, p.35-44.

- SANTOS., R. C.; MAZZON J. A. - Desafios para a intemalização da gestão ambiental nas empresas :um estudo exploratório no Brasil. Washington : BALAS/The George Washington University, 1995. p. 165179. In: Business Association of Latin American Studies. BALAS Proceedings. Washington: BALAS/The George Washington University, 1995. TRABALHO DE EVENTO - unidade FEA - FAC DE ECONOMIA ADMINISTRAÇĀO E CONTABILIDADE

- SÃO PAULO. Constituição( 1989). Constituição do Estado de São Paulo. São Paulo, S.P. Imprensa Oficial do Estado de São Paulo, 1989. 
- SÃO PAULO (Prefeitura do município). Secretária Municipal de Transportes, Companhia de Engenharia de Tráfego. Relatório de Avaliação - Operação horário de pico: você colabora algumas horas e o tránsito melhora todos os dias. PMSPISMT/CET. São Paulo, abri/1998, $64 \mathrm{P}$.

- SÃo PAUlo (Estado). Leis. Decreto no. 42.798, de 12 de janeiro de 1998. In: Secretaria do Meio Ambiente, Programa Estadual de Educação Ambiental Série Documentos Ambientais, 1998.

- SÃo PAUlo (Estado). Secretaria do Meio Ambiente. SÃo PAULO 92 Perfil Ambiental e Estratégias. Secretaria do Meio Ambiente, São Paulo, 1992. 71p.

- SMA. Secretaria do Meio Ambiente. A educação pelo rodizio. Secretaria do Meio Ambiente. São Paulo. $114 p$

- SMA. Secretaria do Meio Ambiente - Parcerias para uma melhor qualidade de vida. Secretaria do Meio Ambiente, São Paulo, 1997. 32 p.

- SMA.Secretaria do Meio Ambiente - Quem somos e o que fazemos. Secretaria do Meio Ambiente, São Paulo, 1998. 90p.

- são paulo (Estado). uma política de estado de uso do PODER DE COMPRA ; Relatório do grupo de trabalho intersecretarial do uso do poder de compra, Governo do Estado de São Paulo, julho/1999,98p.

- SCHEWE, C. D.; SMITH, R. M. Marketing Conceitos, Casos e Aplicações, São Paulo, Mc Graw-Hill, 1982. 564p

- SELLTIZ, C. et al. Métodos de pesquisa nas relações sociais. São Paulo, E.P.U. Editora Pedagógica e Universitária Ltda e EDUSP Editora da Universidade de São Paulo. $5^{\circ}$ reimpressāo, 1975.

- SHAW, R.; STONE, M. Marketing com Banco de Dados, Database Marketing, entendendo e implantando o marketing com banco de dados em qualquer tipo de empresa. São Paulo, Editora ATLAS S.A. 1993. $242 p$ 
- TALVINEN, Jari M., Apud Barrizelli, Nelson; Um modelo de Coleta e Processamento de Informaçōes para a tomada de Decisões de Preços no varejo, Tese apresentada a Universidade de São Paulo - Faculdade de Economia, Administração e Contabilidade, SP, 1995, pg. 15.

- TOledo, G. L.; SANTOS, D. G. A Responsabilidade Social do Marketing. Revista de Administraçāo - IA-USP, v. 14, n.1, p. 45-60 Jan/Mar, 1979

- TOLEDO, Geraldo Luciano; Marketing e relações públicas um conceito tridimensional, Anais do XVIII ENANPAD-MARKETING p 40. [ca.1996]

- VANDERMERWE, S.; OLIFF, M. - Corporate Challenges for na Age of Reconsumption. Columbia Journal of World Business, Vol. 26, n.3 (Fall 1991), p.6-25.

- VAVRA, T. G. Marketing de Relacionamento (Aftermarketing). São Paulo, Editora ATLAS S. A., 1993. 323p

- Webster (Jr), F. E. Aspectos sociais do Marketing. São Paulo, Editora Atlas S.A.,1978. 151p

- YIN, R. K. Case Study research; design and methods, Sage Publications, v.5, Sage Publications, London New Delghi 1989. 165p. 


\section{ANEXO}

\section{ROTEIRO DE ENTREVISTA}

\section{QUESTÕES}

1. Quem era o responsável pelas atividades de marketing da "Operação Rodízio da SMACETESB"? Era formal? Como era estruturada? E como eram a coordenação e a execução das atividades?

2. Quais eram as atividades de marketing desenvolvidas na "Operação Rodízio da SMAVCETESB"? Como eram comunicadas essas atividades?

3. Na SMAVCETESB, havia uma área ou um departamento responsável pelas açōes de disseminação da "Operação Rodizio?"

- A unidade responsável pela disseminação, em caso positivo, mantinha contato com os interessados em adotá-la, como ela funcionava?

- Os técnicos da unidade tinham formação específica em marketing ou algum treinamento especifico nessa área?

- Os técnicos da SMAVCETESB aceitavam bem as ações de maior contato com o público?

- Você acredita que é importante para a SMACETESB conhecer o que a sociedade está disposta a fazer para combater a poluição do ar? Por quê?

- A SMAVETESB deveria desenvolver maior relacionamento, identificar o 
seu público e novos produtos especificos para cada segmento?

4. Qual a forma para se obter informações sobre as ações de combate à poluição do ar que a sociedade deseja/necessita que sejam implantadas?

5. Havia uma estrutura de sistema de informações de marketing na "Operação Rodízio da SMAVCETESB"?

- Em caso afirmativo, como ela foi desenvolvida?

- Como era alimentado o sistema de informações, e qual o critério utilizado na coleta e seleção?

- Quais são as informaçōes de marketing geradas pelo sistema, e como ele é utilizado?

6. Quais foram as pesquisas de mercado desenvolvidas pela SMAVCETESB especificamente para a "Operação Rodízio"?

- O que o programa objetivou com essas informaçōes?

- Como foram tratados os dados, de forma que gerassem informações úteis para o programa, permitindo diferenciar as diversas categorias e públicos relacionados à "Operação Rodizio" SMAVETESB?

- De que forma foram divulgadas e disseminadas essas informações internamente?

7. Quais os critérios e niveis de segmentação adotados para classificar o público-alvo, como Governo, autoridades, frentistas, população?

- A comunicação foi elaborada de forma a atingir diferentes segmentos? 
8. Quais são os benefícios que estão associados à "Operação Rodízio", tangiveis ou intangiveis?

9. O desempenho e a eficiêncialeficácia das açōes do Programa eram mensurados? Qual a base e critério utilizados?

10.De que forma era feito o planejamento de marketing, escrito e formalizado em um plano ou informal através de discussōes e idéias? Havia uma preocupação em controlar as ações estabelecidas? Qual a forma?

11. Havia uma preocupação em envolver os executores do plano no processo de planejamento? Como?

12. Como era estruturado o canal de distribuiçāo dos produtos/serviços?

- Quais os fatores que determinaram essa estrutura?

- Como foram tratados e resolvidos os conflitos que eventualmente tenham surgido no relacionamento entre os integrantes do canal?

13. Quais eram os instrumentos que a SMANCETESB utilizava na comunicação com os diversos públicos da "Operação Rodizio"?

14. Havia campanhas institucionais? Seus custos de adoçāo dos produtos 
oferecidos eram conhecidos?

15. Quem aprovava as campanhas e desenvolvia o posicionamento?

16. Qual o posicionamento da empresa frente a seu público?

- Quais os critérios e as estratégias de posicionamento adotados para a diferenciação dos produtos/serviços da Operação Rodízio para cada público?

- Era presente o posicionamento físico ou psicológico nos materiais de comunicação referentes à campanha junto aos públicos?

17. Como eram elaborados os objetivos de comunicação?

- Escolha da mensagem da propaganda veiculada e principais tipos de mídia, canais e veículos e/ou específicos na divulgação da campanha da Operação Rodízio?

- Quais os critérios utilizados na seleção de canais de comunicação? (cobertura, freqüência e impacto)

- Havia um orçamento total de comunicação?

18. Qual era o público que se pretendia atingir?

19. Quais as dificuldades encontradas no mercado?

20. Quais são os benefícios e atributos comunicados? 
21. A empresa possui alguma agência de propaganda ou assessoria externa?

22. Como é passado o briefing de campanhas e produtos?

23. Como era tratada a mala direta recebida e enviada na empresa?

24. De que forma é feita a comunicação com o público intemo sobre os objetivos e metas a ser alcançados, e de forma geral?

25. Como a organização vê a comunicação para o desenvolvimento de suas atividades, e qual a importância atribuída a ela?

26. Como e quais eram as açōes de relaçōes públicas desenvolvidas? E como eram tomadas as principais decisōes?

- De que forma os funcionários eram conscientizados sobre sua importância na responsabilidade social?

- Havia credibilidade dos funcionários e uma estrutura de vendas da idéia do rodizio no boca a boca?

27. De que forma e quais os fatores estabelecidos nas decisōes sobre o mix de comunicação de marketing, e quais as ferramentas promocionais utilizadas? 
- Havia um desenvolvimento e gerenciamento de programa de propaganda e marketing com objetivos estabelecidos?

- Como era determinado o orçamento e mensurados os resultados? 
APÊNDICE A 


\section{"O que ocorrer com a terra,}

\section{recairá sobre os filhos da terra.}

\section{Há uma ligação em tudo."}

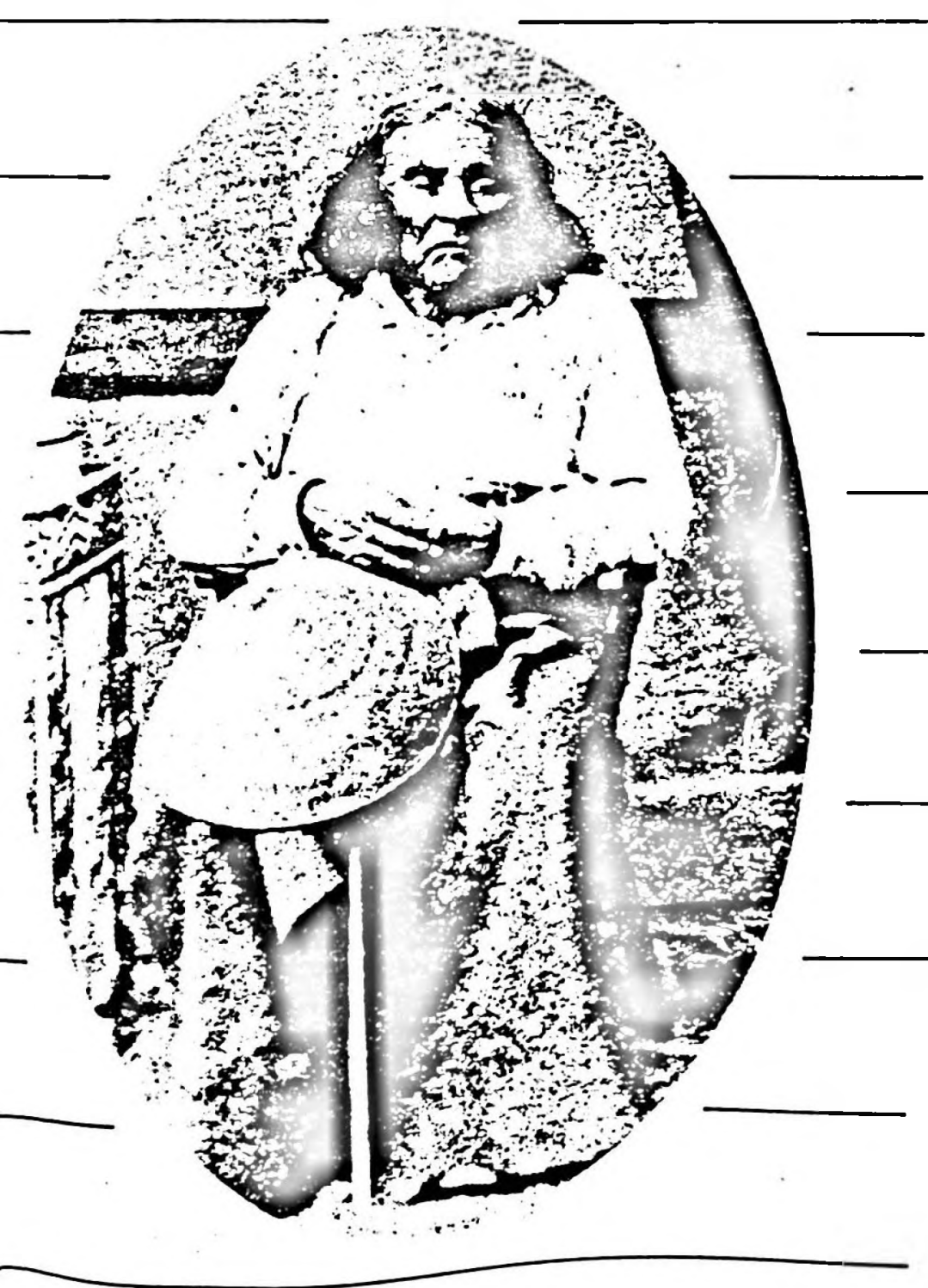

No ano de 1854, o presidente dos Estados Unidos fez a uma tribo indigena a proposta de comprar grande parte de suas terras, oferecendo, em contrapartida, a concessão de uma outra "reserva". O texto da resposta do Chefe Seatle. distribuído pela ONU (Programa para o Meio Ambientel e aqui publicado na íntegra, tem sido considerado, através dos tempos, um dos mais belos e profundos pronunciamentos já feitos a respeito da defesa do meio ambiente.

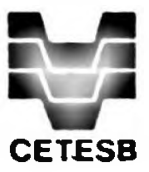

Companhia de Tecnologia de Saneamento Ambiental Secretaria de Obras e Saneamento

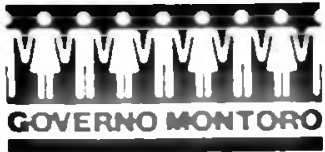


Como t que se pode comprar ou vender o ceu, o calor da terra? Essa ideia nos parece estranha. Se não possuimos o frescor do ar e o brilho da água, como é possivel comprs-los?

Cada pedaço desta terra é sagrado para meu povo. Cada ramo brilhante de um pinheiro, cada punhado de areia das praias, a penumbrai na floresta densa, cada clareira e inseto a zumbir são sagrados na memória e experiência de meu povo. A seiva que percorre o corpo das árvores carrega consigo as lembrancas do homem vermelho.

Os mortos do homem branco esquecem sua terra de origem quando vão caminhar entre as estrelas. Nossos mortos jamais esquecem esta bela terra, pois ela é a mäe do homem vermelho. Somos parte da terra e ela faz parte de nos. As flores perfumadas são nossas irmãs; o cervo, o cavalo, a grande fguia, são nossos irmäos. Os picos rochosos, os sulcos úmidos nas campinas, o calor do corpo do potro, e o homem - todos pertecem à mesma familia.

Portanto, quando o Grande Chefe em Washington manda dizer que deseja comprar nossa terra, pede muito de nós. $O$ Grande Chefe diz que nos reservará um lugar onde possamos viver satisfeitos. Ele será nosso pai e nós seremos seus filhos. Portanto. nós vamos considerar sua oferta de comprar nossa terra. Mas isso não será facil. Esta terra é sagrada para nós.

Essa agua brilhante que escorre nos riachos e rios não el apenas água, mas o sangue de nossos antepassados. Se lhes vendermos a terra, vocês devem lembrar-se de que ela é sagrada, e devem ensinar as suas criancas que ela e sagrada e que cada reflexo nas águas límpidas dos lagos fala de acontecimentos e lembrancas da vida do meu povo. O murmúrio das águas e a voz de meus ancestrais.

Os rios são nossos irmãos, saciam nossa sede. Os rios carregam nossas canoas e alimentam nossas criancas. Se lhes vendermos nossa terra, vocés devem lembrar e ensinar a seus filhos que os rios säo nossos irmãos e seus tambem. $E$, portanto, vocés devem dar aos rios a bondade que dedicariam a qualquer irmäo.

Sabemos que o homem branco nāo compreende nossos costumes. Uma porçāo da terra, para ele, tem o mesmo significado que qualquer outra, pois é um forasteiro que vem à noite e extrai da terra aquilo de que necessita. A terra näo é sua irmä, mas sua inimiga, e quando ele a conquista, prossegue seu caminho. Deixa para trás os túmulos de seus antepassados e não se incomoda. Rapta da terra aquilo que seria de seus filhos e não se importa. A sepultura de seu pai e os direitos de seus filhos são esquecidos. Trata sua mãe, a terra, e seu irmão, o céu, como coisas que possam ser compradas, saqueadas, vendidas como carneiros ou enfeites coloridos. Seu apetite devorara a terra, deixando somente um deserto.

Eu não sei, nossos costumes são diferentes dos seus. A visão de suas cidades fere os olhos do homem vermelho. Talvez seja porque o homem vermelho é um selvagem e não compreenda.

Não há um lugar quieto nas cidades do homem branco. Nenhum lugar onde se possa ouvir o desabrochar de folhas na primavera ou o bater das asas de um inseto. Mas talvez seja porque eu sou um se/vagem e näo compreendo. O ruído parece somente insultar os ouvidos. E o que resta da vida se um homem não pode ouvir o choro solitário de uma ave ou o debate dos sapos ao redor de uma lagoa, à noite? Eu sou um homem vermelho e näo compreendo. $O$ índio prefere o suave murmúrio do vento encrespando a face do lago, e o proprio vento, limpo por uma chuva diurna ou perfumado pelos pinheiros.

O ar é precioso para o homem vermelho, pois todas as coisas comparilham o mesmo sopro - o animal, a arvore, o homem. todos compartilham o mesmo sopro. Parece que o homem branco näo sente o ar que respira. Como um homem agonizante há vários dias, é insensivel ao mau cheiro. Mas se vendermos nossa terra ao homem branco, ele deve lembrar que o ar é precioso para nós, que o ar compartilha seu espírito com toda a vida que mantém. O vento que deu a nosso avô seu primeiro inspirar também recebe seu último suspiro. Se lhes vendermos nossa terra, vocés devem mantê-la intacta e sagrada, como um lugar onde até mesmo o homem branco possa ir saborear o vento açucarado pela flores dos prados.

Portanto, vamos meditar sobre sua oferta de comprar nossa terra. Se decidirmos aceitar, imporei uma condicão: o homem branco deve tratar os animais desta terra como seus irmäos.

Sou um selvagem e não compreendo qualqueir outra forma de agir. Vi um milhar de büfalos apodrecendo na planicie. abandonados pelo homem branco que os alvejou de um trem ao passar. Eu sou um selvagem e não compreendo como e que o fumegante cavalo de ferro pode ser mais importante que o büfalo, que sacrificamos somente para permancer vivos.

O que é homem sem os animais? Se todos os animais se fossem o homem morreria de uma grande solidão de espirito. Pois o que ocorre com os animais, breve acontece com o homem. Há uma ligação em tudo.

Vocés devem ensinar às suas crianças que o solo a seus pés é a cinza de nossos avós. Para que respeitem a terra, digam a seus filhos que ela foi enriquecida com as vidas de nosso povo. Ensinem as suas criancas o que ensinamos as nossas que a terra é nossa mäe. Tudo o que acontecer à terra, acontecerá aos filhos da terra. Se os homens cospem no solo, estäo cuspindo em si mesmos.

Isto sabemos: a terra não pertence ao homem; o homem pertence à terra. Isto sabemos: todos as coisas estäo ligadas como o sangue que une uma familia. Há uma ligạạa em tudo.

O que ocorrer com a terra recairá sobre os filhos da terra. O homem nāo tramou o tecido da vida; ele é simplesmente um de seus fios. Tudo o que fizer ao tecido, fará a si mesmo.

Mesino o homem branco, cujo Deus caminha e fala com ele de amigo para amigo, não pode estar isento do destino comum. É possivel que sejamos irmäos, apesar de tudo. Veremos. De uma coisa estamos certos - e o homem branco poderá vir a descobrir um dia: nosso Deus el o mesmo Deus. Vocês podem pensar que O possuem, como desejam passuir nossa terra; mas näo é possivel. Ele é o Deus do homem, e Sua compaixäo é igual para o homem vermelho e para o homem branco. A terra the é preciosa, e ferf-la e desprezar seu criador. Os brancos também passaräo; talvez mais cedo que todas as outras tribas. Contaminem suas camas, e uma noite serão sufocados pelos próprios dejetos.

Mas quando de sua desaparicão, vocés brilharão intensamente, iluminados pela força do Deus que os trouxe a esta terra e por alguma razäo especial hes deu o dominio sobre a terra e sobre o homem vermelho. Esse destino é um mistério para nós, pois não compreendemos que todos os búfalos sejam exterminados, os cavalos bravios sejam todos domados, os recantos secretos da floresta dendemos que todos os bufalos de muitos homens, e a visão dos morros obstruida por fios que falam. Onde esta o arvoredo? Desapareceu. Onde esta a dguia? Desapareceu. É o final da vida e o inicio da sobrevivéncia. 